(1) Nordregio

\title{
Atlas of population,
} society and economy in the Arctic

\section{2 \\ Leneisja Jungsberg, Eeva Turunen,} Tim Heleniak, Shinan Wang, Justine Ramage and Johanna Roto

NORDREGIO WORKING PAPER 2019:3

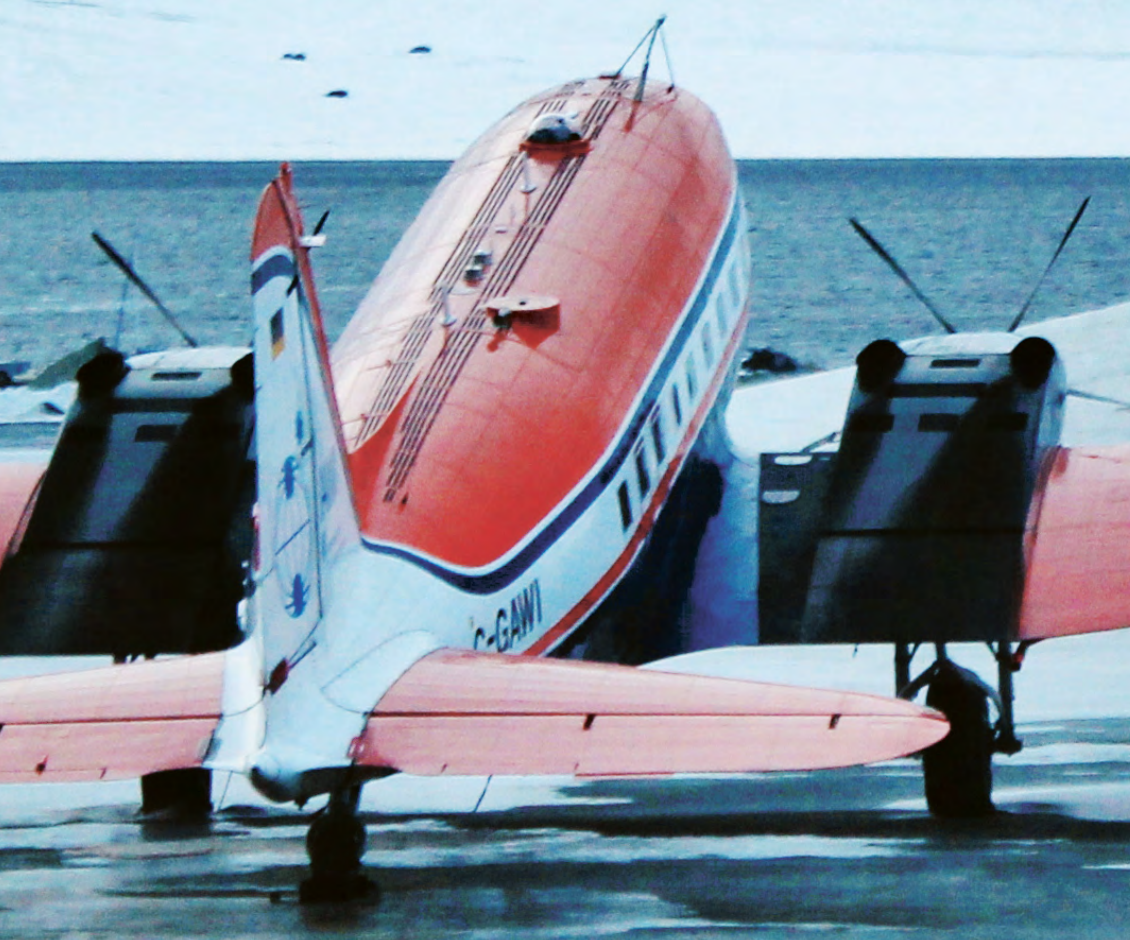





\section{Atlas of population, society and economy in the Arctic}

Leneisja Jungsberg, Eeva Turunen, Tim Heleniak, Shinan Wang, Justine Ramage and Johanna Roto

NORDREGIO WORKING PAPER 2019:3

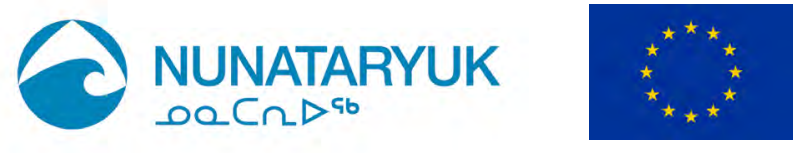


Atlas of population, society and economy in the Arctic

Nordregio Working Paper 2019:3

ISBN: 978-91-87295-79-9

ISSN: $1403-2511$

DOI: doi.org/10.30689/WP2019:3.1403-2511

(C) Nordregio 2019

Nordregio

P.O. Box 1658

SE-111 86 Stockholm, Sweden

nordregio@nordregio.org

www.nordregio.org

www.norden.org

Analyses and text: Leneisja Jungsberg, Eeva Turunen, Tim Heleniak, Shinan Wang, Justine Ramage and Johanna Roto

Maps: Eeva Turunen, Shinan Wang, Justine Ramage and Johanna Roto Layout: Agnes Stenqvist Design

Cover photo: David Broome

\section{Nunataryuk}

This publication is part of the Nunataryuk project. This project has received funding from the European Union's Horizon 2020 research and innovation programme under grant agreement No 773421.

\section{Nordregio}

is a leading Nordic and European research centre for regional development and planning, established by the Nordic Council of Ministers in 1997. We conduct solution-oriented and applied research, addressing current issues from both a research perspective and the viewpoint of policymakers and practitioners. Operating at the international, national, regional and local levels, Nordregio's research covers a wide geographic scope, with an emphasis on the Nordic and Baltic Sea Regions, Europe and the Arctic.

\section{The Nordic co-operation}

Nordic co-operation is one of the world's most extensive forms of regional collaboration, involving Denmark, Finland, Iceland, Norway, Sweden, and the Faroe Islands, Greenland, and Åland. Nordic co-operation has firm traditions in politics, the economy, and culture. It plays an important role in European and international collaboration, and aims at creating a strong Nordic community in a strong Europe. Nordic co-operation seeks to safeguard Nordic and regional interests and principles in the global community. Common Nordic values help the region solidify its position as one of the world's most innovative and competitive.

\section{The Nordic Council of Ministers}

is a forum of co-operation between the Nordic governments. The Nordic Council of Ministers implements Nordic co-operation. The prime ministers have the overall responsibility. Its activities are co-ordinated by the Nordic ministers for co-operation, the Nordic Committee for co-operation and portfolio ministers. Founded in 1971.

\section{The Nordic Council}

is a forum for co-operation between the Nordic parliaments and governments. The Council consists of 87 parliamentarians from the Nordic countries. The Nordic Council takes policy initiative s and monitors Nordic co-operation. Founded in 1952. 


\section{Table of contents}

1. Foreword

2. Executive summary

3. Introduction

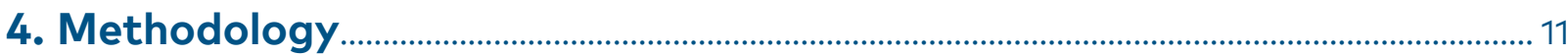

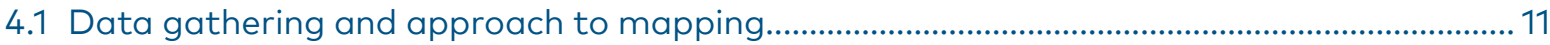

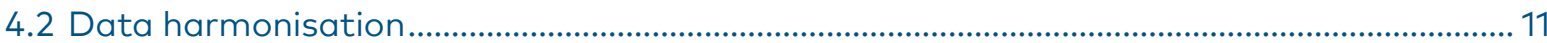

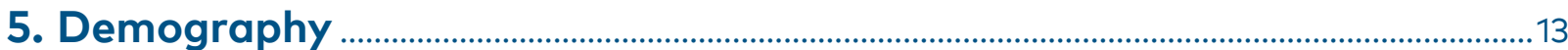

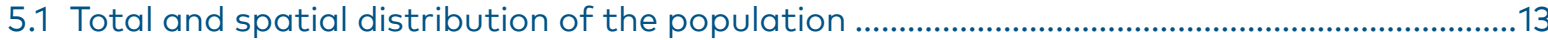

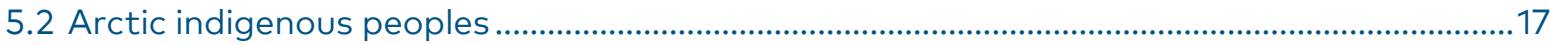

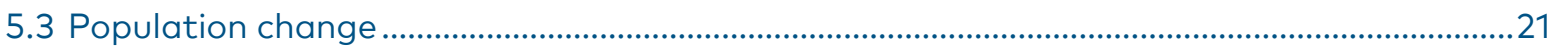

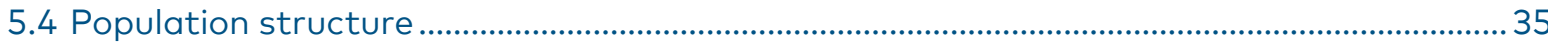

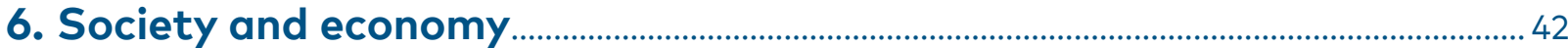

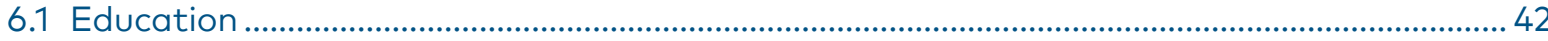

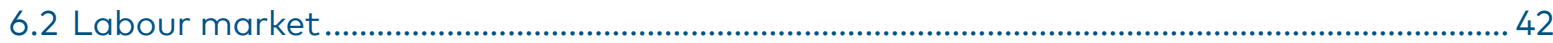

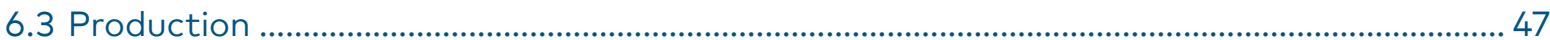

7. Accessibility and infrastructure

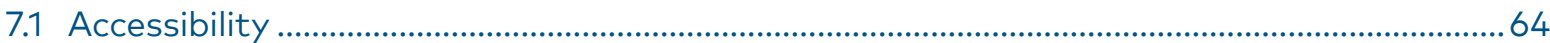

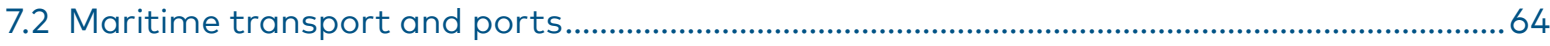

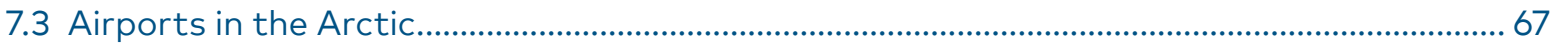

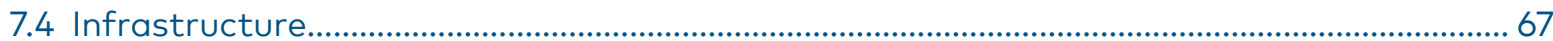

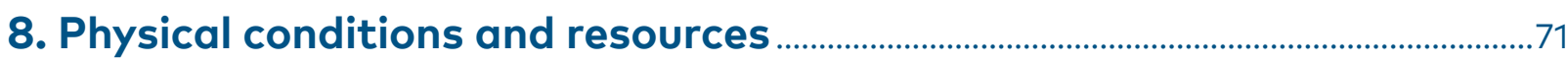

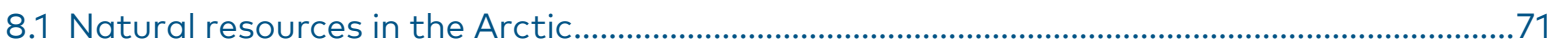

\section{Figures and Maps}

Figure 5-1: Number of settlements by population and settlement size .............................................13

Map 5-2: Arctic settlements by number of inhabitants.................................................................. 14

Map 5-3: $\quad$ Share of the population by settlement size in the Arctic................................................... 15

Figure 5-4: Number of settlements by type and share of the population by settlement type.... 16

Map 5-5: Settlements on permafrost in the Arctic ........................................................................... 18

Map 5-6: Population living on permafrost in the Arctic .............................................................. 19

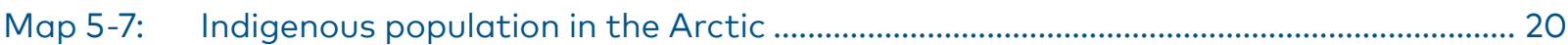

Map 5-8: Population change in the Arctic settlements 2000-2017 .............................................. 24

Map 5-9: $\quad$ Population change in the Arctic settlements: 2010-2017 ...............................................25

Map 5-10: Total population change by components 2013-2017 ..................................................... 27

Map 5-11: Arctic crude birth rate 2013-2017 ….................................................................................28 
Map 5-12: Arctic crude death rate 2013-2017 ........................................................................................29

Map 5-13: Natural population change in the Arctic 2013-2017........................................................... 30

Map 5-14: Infant mortality rate in the Arctic 2012-2016 ....................................................................31

Map 5-15: Life expectancy at birth in the Arctic 2012-2016 .............................................................. 32

Map 5-16: Cause of death by suicide in the Arctic 2012-2016 ........................................................... 33

Map 5-17: Net migration rate in the Arctic 2013-2017.........................................................................34

Map 5-18: Share of youth aged 0-14 in the Arctic in 2017.................................................................36

Map 5-19: Share of youth aged 15-24 in the Arctic in 2017 ................................................................ 37

Map 5-20: Share of the working-age population in the Arctic in 2017 .............................................38

Map 5-21: Share of elderly people in the Arctic in 2017....................................................................39

Map 5-22: Gender balance of total population in the Arctic in 2017............................................. 40

Map 5-23: Gender balance of the working-age population in the Arctic in 2017 ...........................41

Map 6-1: $\quad$ Upper-secondary educational attainment level in the Arctic in 2017........................... 43

Map 6-2: Tertiary educational attainment level in the Arctic in 2017............................................44

Map 6-3: Higher educational institutions in the Arctic .....................................................................45

Map 6-4: Labour force participation rate in the Arctic in 2016 ........................................................ 49

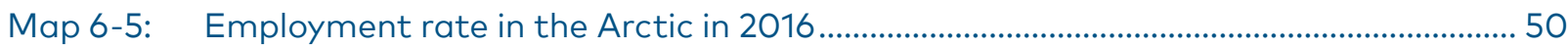

Map 6-6: Part-time employment incidence in the Arctic in 2014 ..................................................51

Map 6-7: $\quad$ Unemployment rate in the Arctic in 2016 .......................................................................52

Figure 6-8: Arctic youth unemployment rate in 2014, national level .................................................53

Figure 6-9: Arctic youth unemployment rate in 2016, regional level................................................53

Map 6-10: Employment in public sector in the Arctic in 2017.........................................................54

Map 6-11: Employment in private sector in the Arctic in 2017 ......................................................55

Map 6-12: Employment in primary sector in the Arctic in 2016 ......................................................56

Map 6-13: Employment in secondary sector in the Arctic in 2016 ......................................................57

Map 6-14: Employment in tertiary sector in the Arctic in 2016 ........................................................58

Map 6-15: Cluster analysis of employment in the Arctic in 2016 .....................................................59

Map 6-16: Gross Regional Product per capita in current PPP in the Arctic in 2016 ...................... 60

Map 6-17: Gross Value Added in current PPP in the Arctic in 2016 ...................................................61

Figure 6-18: Gross disposable household income per capita in 2015 ...............................................62

Map 6-19: Housing by type of dwellings in the Arctic in 2016 .......................................................63

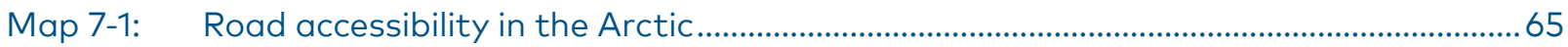

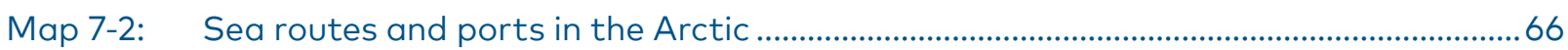

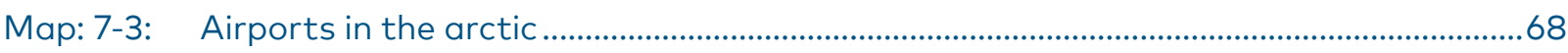

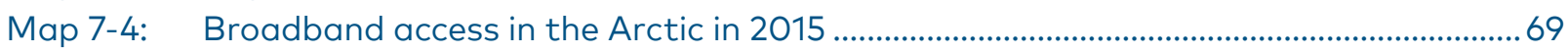

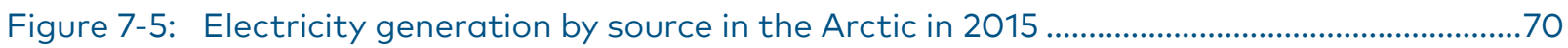

Map 8-1: Components of the cryosphere in the Arctic .................................................................... 73

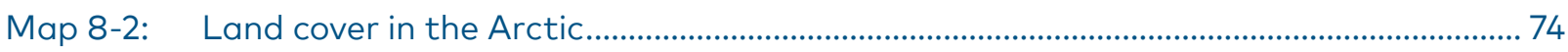

Map 8-3: $\quad$ Protected land and sea areas in the Arctic.........................................................................75

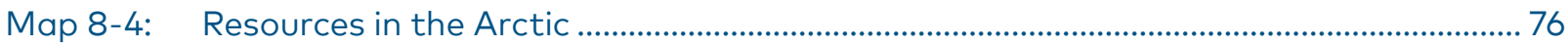




\section{Foreword}

This working paper is part of the Horizon 2020 project Nunataryuk: Permafrost thaw and changing Arctic coast - science for socio-economic adaptation. The research was also carried out under the aegis of the EU Arctic Cluster. The Cluster's objective is to provide guidance and policy-relevant information in support of the EU's efforts to develop international cooperation aimed at ameliorating the impacts of climate change in the Arctic, as well as promoting and contributing to sustainable development.

In terms of sustainable development, Nunataryuk works with an interdisciplinary team of researchers in the physical and social sciences, who conduct integration analysis of permafrost thaw and community development in the circumpolar Arctic. The social science component entails, among other things, producing maps that illustrate demographic and societal factors, based on standardised indicators. These results are also related to research conducted within the Nunataryuk project's physical science and integration components.

Hugues Lantuit

Kjell Nilsson

Project Coordinator 


\section{Executive summary}

Demographic trends across the Arctic regions differ considerably in terms of population size, growth rates, the structure of settlements, fertility and migration patterns.

Settlement patterns indicate that two-thirds of the Arctic population live in settlements with more than 10,000 inhabitants. However, some regions are characterised by a dispersed population living in numerous small settlements (fewer than 5,000 inhabitants). In Alaska (USA) and the Russian Arctic, a large share of the population lives in larger settlements. The exception is Chukotka in Russia, where more than half of the population live in small settlements of fewer than 5,000 inhabitants. In Nunavut and Northern Quebec (Canadian Arctic), Greenland, the Faroe Islands, and Finnmark (Norway), most of the population live in small settlements.

Permafrost is widespread in the Arctic. In total, $60 \%$ of Arctic settlements are located on permafrost, of which $46 \%$ are coastal. More than two-thirds of the population in the Arctic live in settlements located on permafrost. Increasing air temperatures in the Arctic mean permafrost is thawing, which has serious consequences for the majority of the inhabitants of the Arctic region.

Population change is the result of net migration and natural population change. The Arctic region has seen continuous migration into larger urban centres and a decline in smaller settlements. Alaska (USA) and the Canadian Arctic have experienced significant population growth in recent decades. In the Nordic Arctic, the population of Iceland has also grown significantly. The populations of Greenland and the Faroe Islands, on the other hand, have changed very little. In all Norwegian Arctic regions, the population has grown. Despite a decline in some Swedish and Finnish Arctic regions, these areas have experienced moderate overall growth. The population of the Russian Arctic has continued its post-Soviet contraction, with ongoing decline in all but the urban districts.

Indigenous people comprise a significant share of the Arctic population, especially in the Canadian Arctic and Greenland, where $75 \%$ or more are indigenous. In many other regions, the share

\section{RESUMÉ}

Dette Atlas viser status og seneste års udvikling for befolkning, samfund, økonomi, natur-resourcer og infrastruktur i de Arktiske regioner. Formålet med Atlas'et er at give mulighed for at sammenligne de forskellige regioner i Arktis på en række demografiske og social-økonomiske indikatorer. Al data er fra OECD eller nationelle statitiske databaser og analyserne viser harmoniserede indikatorer på regional eller sub-regionalt/ kommunalt niveau.

Resultaterne fra rapporten giver et overblik i forhold til demografi og migrationsmønstre, antal af byer og landsbyer der er bygget på permafrost, andelen af oprindelige folk, fordelingen af befolkning med gymnasiel, bachelor og erhvervsuddannelse, huse og transport infrastruktur, indkomstniveau og erhvervs aktiviteter samt naturresourcer i de Arktiske regioner.

of indigenous people as part of the total population is around $50 \%$. This includes Sakha (Russian Federation) and northwestern Alaska (USA). Approximately one million people, or $9 \%$ of the total population of the Arctic region, are indigenous, representing over 40 different ethnic groups. Statistically speaking, there is no circumpolar definition for an indigenous person. As such, the number of indigenous people is based on different national definitions.

Population structure shows the gender ratio and the proportions of young people (aged 0-14), the working-age population (15-65), and elderly people (over 65). Generally, there are more males living in the Arctic regions, with the exception of the Russian Arctic, where females represent a higher share, particularly in the larger urban centres. Young people (aged $0-14$ ) are well represented in the Arctic, accounting for more than $30 \%$ of the population in the Russian and Canadian Arctic and in Alaska (USA). Across the Arctic region as a whole, the share of the working-age population is $69.8 \%$. 
The old-age dependency ratio is low across most of the Arctic, but high in the Nordic Arctic, where more than $20 \%$ of the population are elderly.

Society and economy in the Arctic regions are characterised by a high level of dependence on natural resources. Several Arctic regions have a higher disposable income per capita than the national average. Across the Arctic, the public sector accounts for around one-third of all employment, while the private sector accounts for two thirds.

Education indicators reveal that the upper secondary education attainment level is above $80 \%$ in the Yukon, Labrador (Canada), Norrbotten (Sweden) and Lappi (Finland.) The lowest shares of individuals with upper-secondary education are in Greenland (45.6\%), Chukotka (Russian Federation) (58.4\%) and Nunavut (Canada) (59.1\%). The highest shares of the workforce with tertiary education (equivalent to bachelor or similar) are in Troms (Norway) (43.8\%), Iceland (42.5\%) and other Nordic regions, as well as Yukon (Canada) (33.3\%) and some parts of Alaska (USA).

Labour market analysis shows a range of main employment sectors. The primary sector represents $14 \%$ of economic activity in the Arctic, while the secondary sector represents $20 \%$. The tertiary sector, also known as the service sector, has the largest share of employment (66\%). A relatively high share of employees work in the tertiary sector in Alaska (USA) and the Canadian Arctic, except for Labrador. On the contrary, there is a low share of service-related employment in the Russian Arctic. High employment rates in the Arctic regions can be found in the Faroe Islands, Svalbard (Norway), Yukon (Canada), and Chukotka, YamaloNenets and Magadan Oblast (Russian Federation). The lowest employment rates are in Finnish Lapland, as well as Nunavut and Newfoundland and Labrador (Canada).

Production is represented by the GDP (Gross Domestic Product) and GRP (Gross Regional Product), which measures the overall economic output of all economic activities in a country or region, measured in terms of PPP (purchasing power parity). The average Arctic GRP in PPP is $€ 40,000$. Alaska (USA), the Canadian Arctic and the Nordic Arctic region perform well in relation to the Arctic average. All regions are above the Arctic average except Northern Quebec (Canada) and Lappi (Finland). Alaska (USA), the Northwest Territories (Canada) and Svalbard (Norway) are the best per- formers. In the Russian Arctic, there are large differences between regions. Nenets, Yamalo-Nenets and Khanty-Mansi are among the best performers in the Arctic, while the remaining regions had a GRP in PPP far below the Arctic average.

Accessibility and infrastructure are crucial for connecting settlements in the Arctic. This part focuses on land-, air- and sea-based transportation networks, as well as road, railway, airport and port infrastructure in the Arctic regions.

Road infrastructure is considerably less dense in areas with continuous permafrost. Settlements in Greenland, Nunavut, Nunavik and Labrador (Canada) are not connected by road networks, and there are only scarce road segments between adjacent settlements. As such, travel by road remains a challenge in these regions. Alaska (USA), the Northwest Territories and Yukon (Canada) have better road infrastructure.

Maritime routes have experienced significant growth in traffic in recent years. Between 2016 and 2017, the cargo volume in the Northern Sea Route increased by nearly $40 \%$.

Airports are extremely important in the Arctic due to the long distances between settlements and the lack of road networks. There are seven large and 260 medium-sized airports across the Arctic.

Resources in the Arctic are considerable. Exploration and transport facilities for oil, gas, and mineral resources are increasing throughout the circumpolar region.

Oil and gas exploitation is mostly concentrated in the Beaufort Sea area (North Slope of Alaska and the Mackenzie Delta) and northwest Russia (Barents Sea and West-Siberia). Oil and gas are also found in the Canadian Arctic Archipelago (Nunavut). These three regions are also targeted for future exploitation.

Mining sites are constantly moving farther north due to technical development, permafrost thaw and declining sea-ice. These factors allow for the exploitation of previously inaccessible resources.

Access to natural resources is highly dependent on technical capacities and environmental challenges, which lead to higher extraction costs. The high economic costs of exploitation and transportation, as well as high demand for environmental protection, are decisive factors in the exploitation of Arctic resources. 


\section{Introduction}

The objective of the Atlas of Population, Society and Economy in the Arctic is to provide an in-depth overview of the changes that are affecting populations in the circumpolar North. Continuous environmental, economic and social changes are currently underway in the Arctic regions. Global warming, for example, is challenging traditional livelihoods, accessibility and economic activities. The atlas presents a collection of standardised indicators that illustrate the state of the Arctic regions focusing on demography, society, economy, production, accessibility and infrastructure as well as physical conditions and resources in the Arctic. As part of Nunataryuk's research, this working paper examines the environmental challenges related to permafrost by combining geographical data with demographic data in order to describe coastal and inland settlements. Permafrost thaw is a challenge for many Arctic communities, as it has an impact on infrastructure, economy and the health of Arctic populations.

The Atlas focuses on the entire circumpolar North in order to provide a basis for regional comparative analysis and to serve as a tool for policy-makers, regional planners, academia and students. It presents data via a series of maps that illustrate trends in a clear and understandable format. Each section consists of descriptive text and several maps that depict the past and present status of selected indicators. This working paper should be seen in the broader context of the Nunataryuk research project as a whole. Many of the study areas and definitions of Arctic regions are based on cooperation with natural scientists, in order to combine permafrost data with population data.

The natural and social sciences employ different definitions of the Arctic. Most are based on physical and geographical boundaries and delimitations. Most commonly, the Arctic is defined as the region above the Arctic Circle (66 34' N) that marks the latitude above which the sun does not set on the summer solstice and does not rise on the winter solstice. Other common delimitations are based on climate and vegetation boundaries. This atlas uses the definition from the Arctic Human Development Report (AHDR) ${ }^{1}$ as a point of departure and adapts it to the scope of the study. Adaptations from the AHDR definition were made for several reasons. First, the definition was adapted to reflect the geopolitical divisions and classifications that have arisen since 2004, when the AHDR definition was established. Second, a few regions comprising large areas with permafrost were added, in order to reflect the Nunataryuk project's focus on impacts of permafrost thaw. This study therefore also includes Kamchatka, Magadan, Khanty-Mansi and Sakha (Russian Federation).

The knowledge gathered in this report serves as the basis for further research. It also provides input to a research question within the social science component of the Nunataryuk project: What is the socio-economic status of the Arctic? It gathers and harmonises various standardised indicators from different sources in order to provide an overview of the Arctic as a whole, understand its socio-economic status and allow for comparisons at regional level. 1 AHDR (Arctic Human Development Report) 2004. Akureyri:
Stefansson Arctic Institute. http://norden.diva-portal.org/
smash/get/diva2:788965/FULLTEXTO3.pdf 


\section{Methodology}

\subsection{Data gathering and approach to mapping}

All data come from publicly available open statistical databases, primarily national statistical institutes and the OECD database. There were three main sources of demographic data - population censuses, administrative and register data, and surveys. Population censuses are, by definition, complete enumerations of a population (or at least attempts at such). These can vary from simple headcounts that gather minimal, basic demographic information, such as age and sex, to more comprehensive exercises that collect information on, e.g. race or ethnicity, family or household composition, housing type, migration patterns and citizenship. In the United States, population censuses have been conducted every ten years since 1790 in years ending in 'O'. Canada conducts population censuses every five years in years ending in ' 1 ' and ' 6 '. Russia has conducted population censuses irregularly over the past century, in 1897, 1926, 1939, 1959, 1970, 1979, 1989, 2002 and 2010. The Nordic countries no longer conduct traditional population censuses, and instead now rely mostly on population registers.

A second source of demographic information is administrative data, which governments collect and compile typically for purposes other than population analysis, and can encompass a wide variety of different topical areas. The Alaska Permanent Fund is an example of how administrative data can be used for population analysis. It is funded by oil revenues and pays out an annual dividend to each resident of the state. Since each person must establish residency to receive their dividend, anonymised data can be used in migration analysis. Register data are typically collected with the express purpose of tracking populations. The Nordic countries rely heavily on register data, starting with a person's birth or entry into the country.

The data-gathering process is tailored to different areas, because the countries concerned do not always have the same administrative or statistical system of territorial divisions. Therefore, a multi-scalar approach is applied, which uses available data to highlight different socio-economic characteristics at different geographical levels. The basic geographical scale for monitoring socio-economic status and trends is determined by the administrative level concerned - mainly the regional and sub-regional levels. Data on most of the indicators are available at regional level. However, for some indicators, more aggregated spatial levels (e.g. national level or other statistical delimitations) are used due to lack of data. Appendix Table 1 describes the administrative structures in the Arctic Region.

\subsection{Data harmonisation}

Data harmonisation mainly consists of examining metadata from the data sources in order to ensure they come from the same period, represent the same group and use the same method. The harmonisation process also involves a degree of calculation, since some indicators are only available as proportions rather than raw data. Calculations are also needed due to different data availability for the time period concerned. For example, limited data availability of the 2002 Russian census means that population estimates had to be calculated for some small Russian settlements. These estimates are based on the settlements' average annual growth rate. In many cases, it proved impossible to harmonise the data based on identical definitions. Certain datasets are based on different age groups, and therefore cannot be harmonised. Due to these differences, we have calculated several estimates ourselves in order to present data that are as harmonised as possible for all countries.

The regions and countries included in the Arctic as defined in this report are: Alaska (United States); Yukon, the Northwest Territories, Nunavut, Newfoundland and Labrador, Northern Quebec (Canada); Nordland, Troms, Finnmark, Svalbard (Norway); Norrbotten (Sweden); Lappi (Finland); Murmansk, Komi, Arkhangelsk, Nenets, KhantyMansi, Yamalo-Nenets, Krasnoyarsk, Sakha, Kam- 
chatka, Magadan, Chukotka (Russian Federation), ${ }^{2}$ as well as all regions in Greenland; Iceland; and the Faroe Islands (more details in Appendix Table 1.2).

The maps' territorial level and geographical coverage differ due to variations in the availability of data for the different indicators. For most of the demographic indicators, data is available at sub-regional level, and the total population data is as detailed as at settlement level. Indicators describing the society and economy are generally available at regional level. Only sparse data are available on Arctic infrastructure and natural resources. For some indicators (e.g. electricity generation by source), data is only available at national level. Each map clearly specifies the extent of the geographical coverage.

2 The definition of the Arctic in the Russian Federation used here is specific to this report and differs from other official definitions. The Russian Federation classifies regions as Arctic or Northern based on social, economic, geographic and climatic criteria. 


\section{Demography}

When assessing the socio-economic impacts of permafrost thaw in the Arctic, it is crucial to understand the demographic components. Assessing and understanding population changes over time and population structures is a prerequisite for city planners, infrastructure planners and those working with regional economy. An analysis of demographic structures can be used to predict demand for new housing or the likelihood that housing will be abandoned, identify the required capacity for road infrastructure or plan a strategy for disaster management.

From an economic point of view, understanding population trends helps policy- and decision-makers to allocate resources. Demographic structure has an effect on the local economy, and therefore it can be used to assess how employment levels are likely to develop or a region's expected economic productivity. In order to ensure sustainable lifestyles, it is important to determine whether a population is increasing, as well as the average age and expected lifespan.

This section presents demographic maps and analyses of five main demographic aspects: i) the distribution, number, and size of settlements; ii) the share of the population living on permafrost; iii) the total population change and the changes by component; iv) the share of Arctic indigenous peo- ples in the total population; and v) the population's age structure and gender balance.

\subsection{Total and spatial distribution of the population}

In 2017, the total population of the Arctic was 7,088,482 inhabitants, spread over 1,500 established settlements. As shown in Figure 5-1: Number of settlements by size and share of the population by settlement size, the population is concentrated in a few large settlements that account for a small proportion of the number of Arctic settlements. Most of the settlements (90.5\%) have fewer than 5,000 inhabitants (Fig. 3-1a). Of the seven million inhabitants, $74.3 \%$ live in settlements with populations of at least 5,000. The remaining $25.7 \%$ live either in settlements with fewer than 5,000 inhabitants or outside any established settlement (7.2\%), as illustrated in Figure 5-1.

Arctic settlements differ considerably in terms of their social and physical conditions. Figure 5-1: Number of settlements by population and settlement size shows the type of settlements by population in 2017. The yellow markers indicate settlements with fewer than 5,000 inhabitants, while the blue markers indicate three types of settlements with at least 5,000 inhabitants. Most of the Arctic settlements are small (fewer than

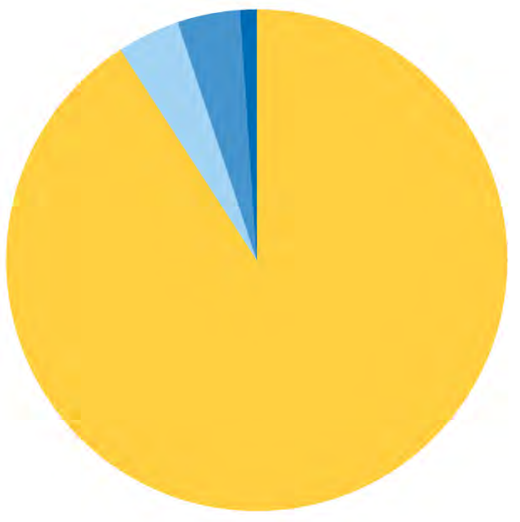

A) Share of settlements by settlement size in the Arctic

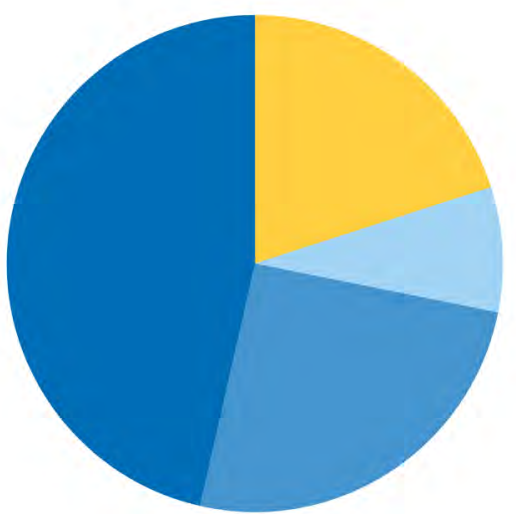

B) Share of population by settlement size in the Arctic
Settlement size: number of inhabitants in 2017

$>50,000$

$10,000-50,000$

$5,000-10,000$

$<5,000$

Figure 5-1: Number of settlements by population and settlement size. 


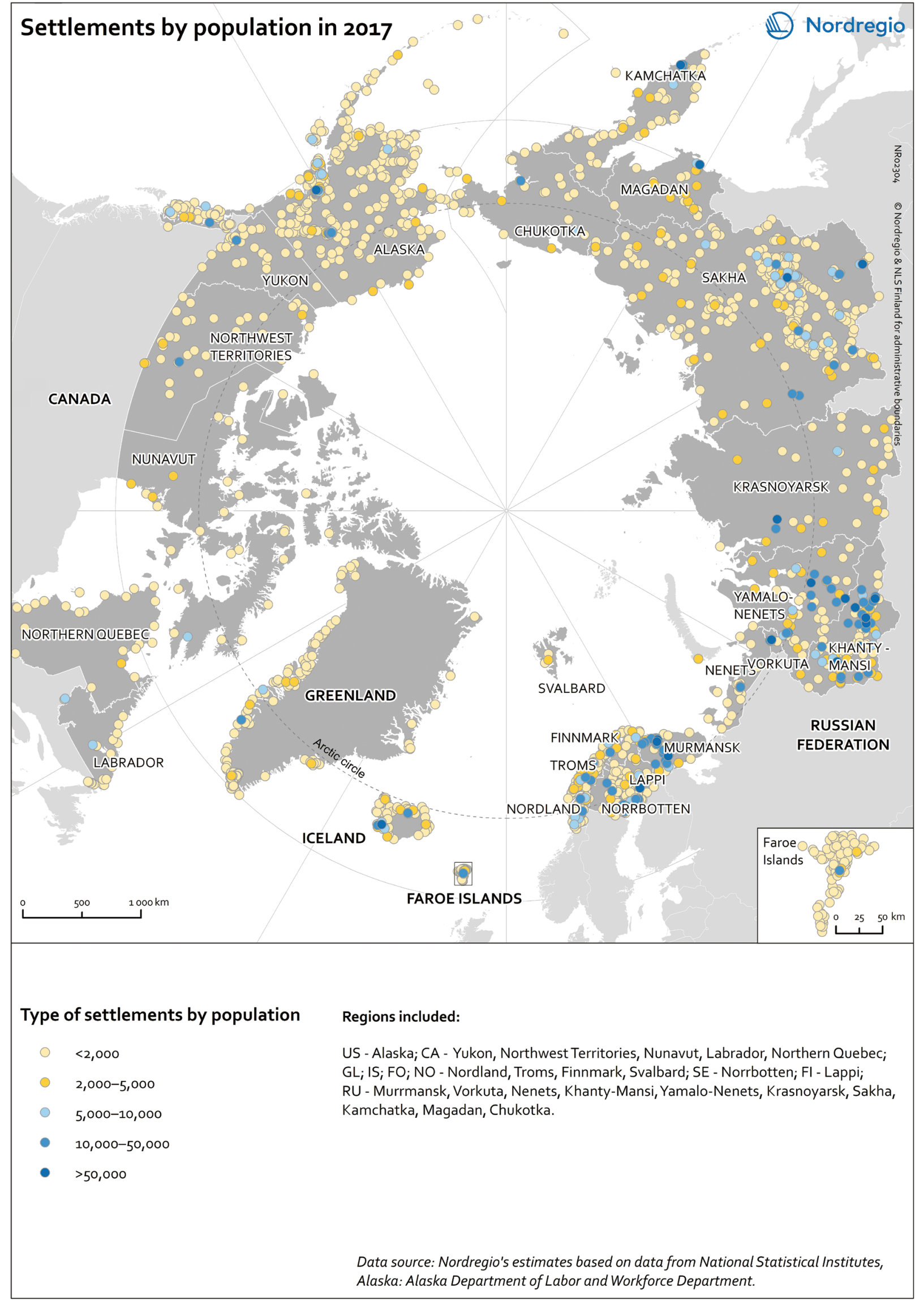

Map 5-2: Arctic settlements by number of inhabitants. 


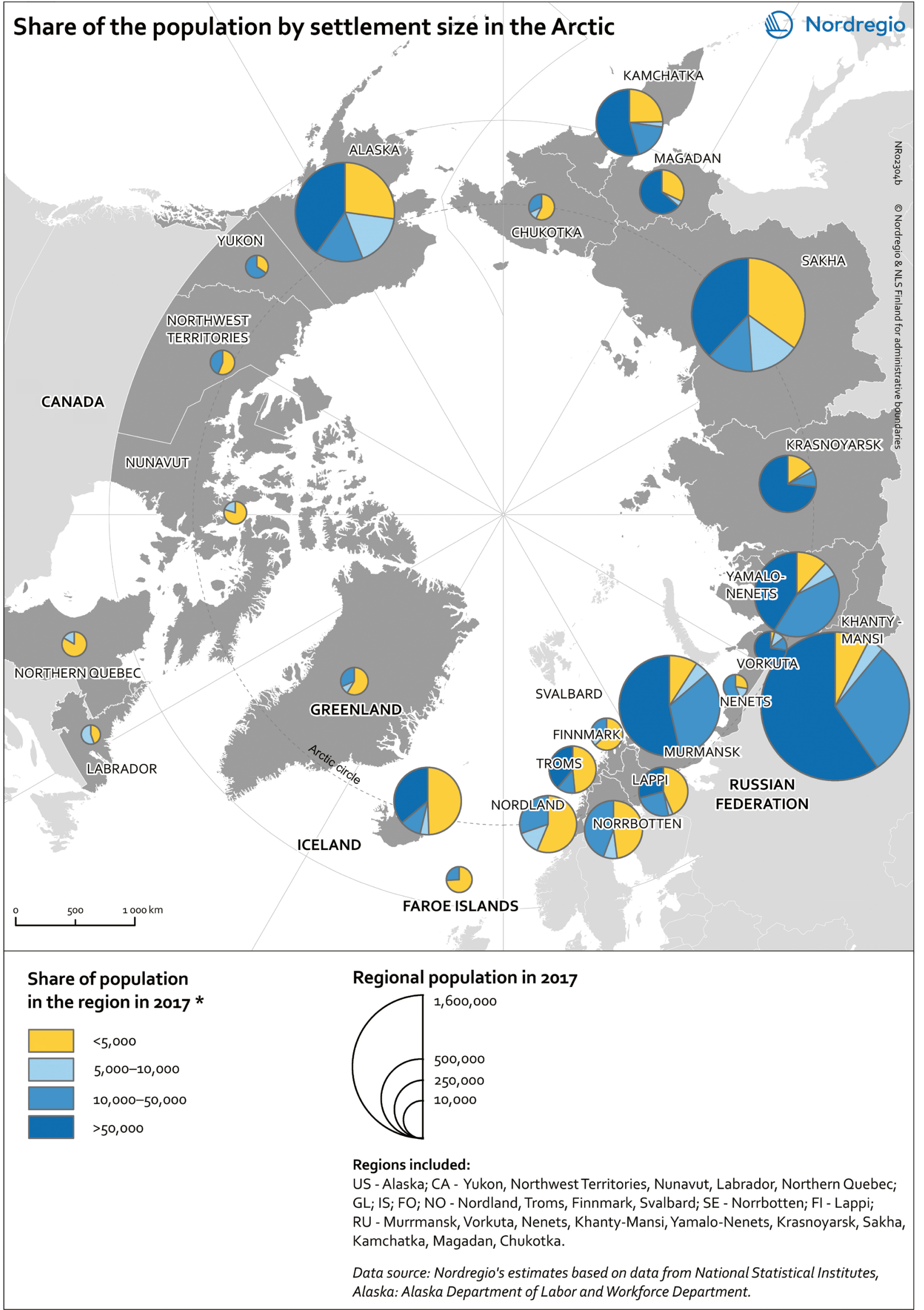

Map 5-3: Share of the population by settlement size in the Arctic. 
5,000 inhabitants). The large settlements are mainly regional/administrative centres, especially in the Canadian Arctic, Greenland, Iceland, the Faroe Islands and most regions of the Russian Arctic. In Alaska (USA), Arctic Fennoscandia, YamaloNenets, Khanty-Mansi and Sakha (Russian Federation), the settlement density is high, with many large settlements. Even though small settlements outweigh large settlements in terms of number, inhabitants living in settlements with more than 5,000 inhabitants represent most of the Arctic population (74.3\%). However, this pattern differs across the Arctic, as shown in Map 5-2 and Map 5-3. In Map 5-3, the colours indicate the share of the population in small (fewer than 5,000 inhabitants) and large (more than 5,000 inhabitants) settlements. The size of the circle corresponds to the total regional population in 2017. In Alaska (USA) and the Russian Arctic, a large share of the population lives in large settlements. The exception is Chukotka, in which more than half of the population live in small settlements. In Nunavut and Northern Quebec (Canada), Greenland, the Faroe Islands and Finnmark (Norway), the majority of the population live in small settlements. The Yukon differs from other Canadian Arctic regions due to its regional centre Whitehorse, which accounts for $65 \%$ of the population. In the rest of the Arctic - the Northwest Territories and Labrador (Canada), Iceland, Troms and Nordland (Norway), Norrbotten (Sweden) and Lappi/Lapland (Fin- land), there is less of a disparity between the share of the population in small and large settlements.

Among all Arctic settlements, $66.1 \%$ are located on permafrost. Settlements are classified as permafrost settlements if they are located within the permafrost extent, i.e. zones characterised by continuous, discontinuous, sporadic or isolated permafrost (see Figure 5-4). Among all permafrost settlements, $46.0 \%$ are coastal (Figure 5-4a). Coastal settlements are defined by their dependency on the sea. They are either adjacent to the coast, located inland along large rivers with ready access to the open sea, or located a short distance from the sea $(0-200 \mathrm{~km})$. In our study, coastal settlements are defined as all settlements located within an Arctic sub-region adjacent to the coast. An exception was made for Yukon (Canada), where coastal settlements were identified based on our knowledge of the area. The majority of the population in the Arctic (61.3\%) live in settlements located on permafrost, of which $31.1 \%$ are coastal settlements (Figure 5-4).

Map 5-5: Settlements on permafrost in the Arctic shows the distribution of coastal and inland settlements on permafrost in 2017. The purple markers indicate settlements located on permafrost. A distinction is made between coastal (light purple) and inland (dark purple) settlements. Settlements located outside of the permafrost are indicated by yellow markers. Most of the settlements located outside the permafrost are in the Nordic coun-

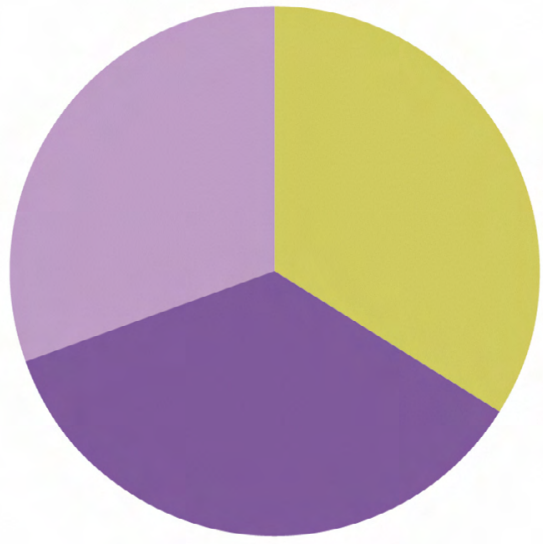

A) Number of settlements on permafrost in the Arctic.

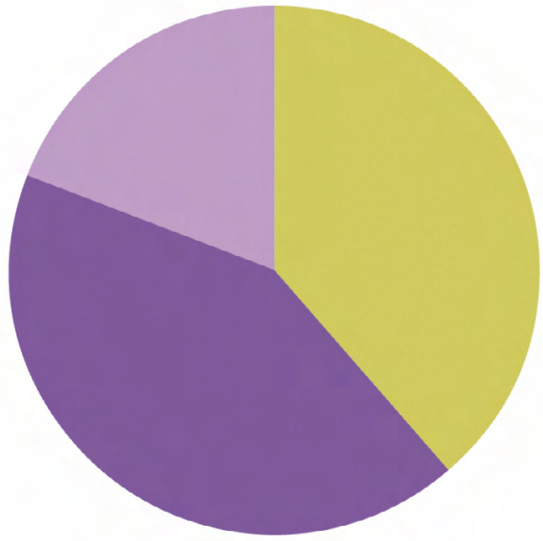

Type of settlement

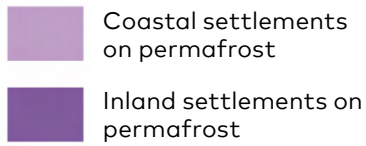

Settlements outside the permafrost extent

Figure 5-4: Number of settlements by type and share of the population by settlement type. 
tries (Iceland, Norway, the Faroe Islands, Sweden and Finland), the southern part of Alaska (USA) and the western part of the Russian Arctic. Map 5-6: Population living on permafrost in the Arctic shows the share of the population living in settlements located on permafrost at the regional level in 2017. While majority of the population in the Arctic live on permafrost, regional differences are evident. A small portion of the Arctic population from the Nordic countries, as well as from Alaska (USA), Kamchatka, and Murmansk (Russian Federation), live in settlements on permafrost. On the contrary, in the most densely populated Arctic regions - Khanty-Mansi, Yamalo-Nenets and Sakha (Russian Federation) - a large majority of the population live in permafrost settlements. The majority of those in permafrost settlements live by the coast, except in Sakha and Khanty-Mansi (Russian Federation), Yukon and the Northwest Territories (Canada). Coastal settlements on average have a lower population density (mean $=2,428.4$ inhabitants) than Arctic settlements (mean $=3,501.8$ inhabitants). This demographic structure is specific to the Arctic, and should be considered when assessing the impact of climate change on the Arctic population.

\subsection{Arctic indigenous peoples}

Approximately one million people, or $9 \%$ of the total Arctic population, are indigenous. The indigenous population comprises more than 40 different ethnic groups. Statistically speaking, there is no circumpolar definition of an indigenous person. As such, the number of indigenous people is arrived at based on different national definitions. Official statistics do not necessarily distinguish between indigenous populations.

Saami people live in northern Fennoscandia. There are no national data on the number of Saami people, as neither Finland, Norway nor Sweden publish ethnicity-based data. The estimates used in the following maps indicate a total of approx. 80,000 Saami people, based on data from the national Saami parliaments.

Invits (Kalaallit) are a majority in Greenland. Like the other Nordic Countries, Greenland does not categorise people based on ethnicity or race, but by place of birth. Greenlanders (approx. 50,000 in total) are those born in Greenland and therefore statistically referred to as indigenous.

The aboriginal peoples of Canada are defined in the Constitution Act of 1982, section 35 (2) as including the Indian (First Nations), Invit and Métis peoples of Canada. 'Aboriginal identity' encompasses persons who are First Nations, Métis or Inuk (Inuit), and/or (registered as) Treaty Indians, and/or members of a First Nation or Indian band. Some 100,000 indigenous people are classified as aboriginal in the Canadian census data.

Alaska Natives are the indigenous peoples of Alaska (USA), and include the Yupik, Tsimshian, Eyak, Tlingit, Haida, Iñupiat, Aleut, and several Northern Athabaskan cultures. There are approximately 150,000 indigenous people in Alaska (USA).

The Russian Federation officially recognises 40 indigenous tribes in the Russian Arctic as 'indigenous small-numbered people'. According to the Russian census, 'Indigenous small-numbered peoples of the North, Siberia and the Far East' refers to groups living in the Russian Arctic numbering fewer than 50,000 persons. Our data also include Komis and Yakuts, and accounts for some 670,000 indigenous people living in the Russian Arctic. The largest groups are the Yakuts, Komis, Nenets, Khantys, Evenkis and Chukchis.

Map 5-6: Population living on permafrost in the Arctic illustrates the share of indigenous population as a percentage of the total population in each region in 2016. The highest share is found in the Canadian Arctic and Greenland, where more than $75 \%$ of the total population are indigenous. The southern part of Northern Quebec, Yukon, and Newfoundland and Labrador (Canada) have the lowest shares of indigenous population. In the remaining part of the Arctic, indigenous peoples represent less than half of the total population, except in Sakha (Russian Federation), the Southwest Region and the Northern Region (Alaska, USA) where $50-75 \%$ of the population are indigenous. There are no indigenous people in Iceland, the Faroe Islands and Svalbard. 


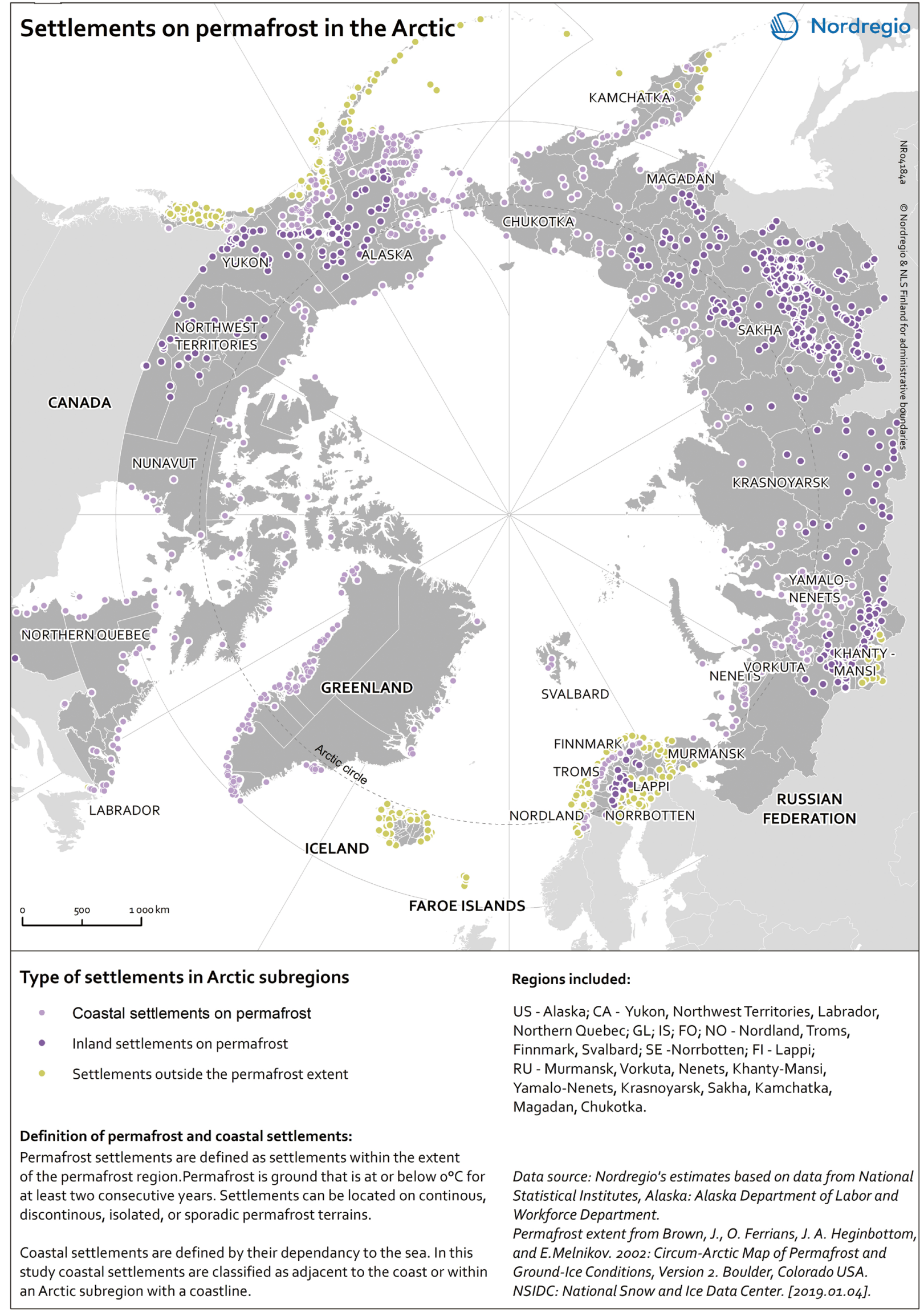

Map 5-5: Settlements on permafrost in the Arctic 


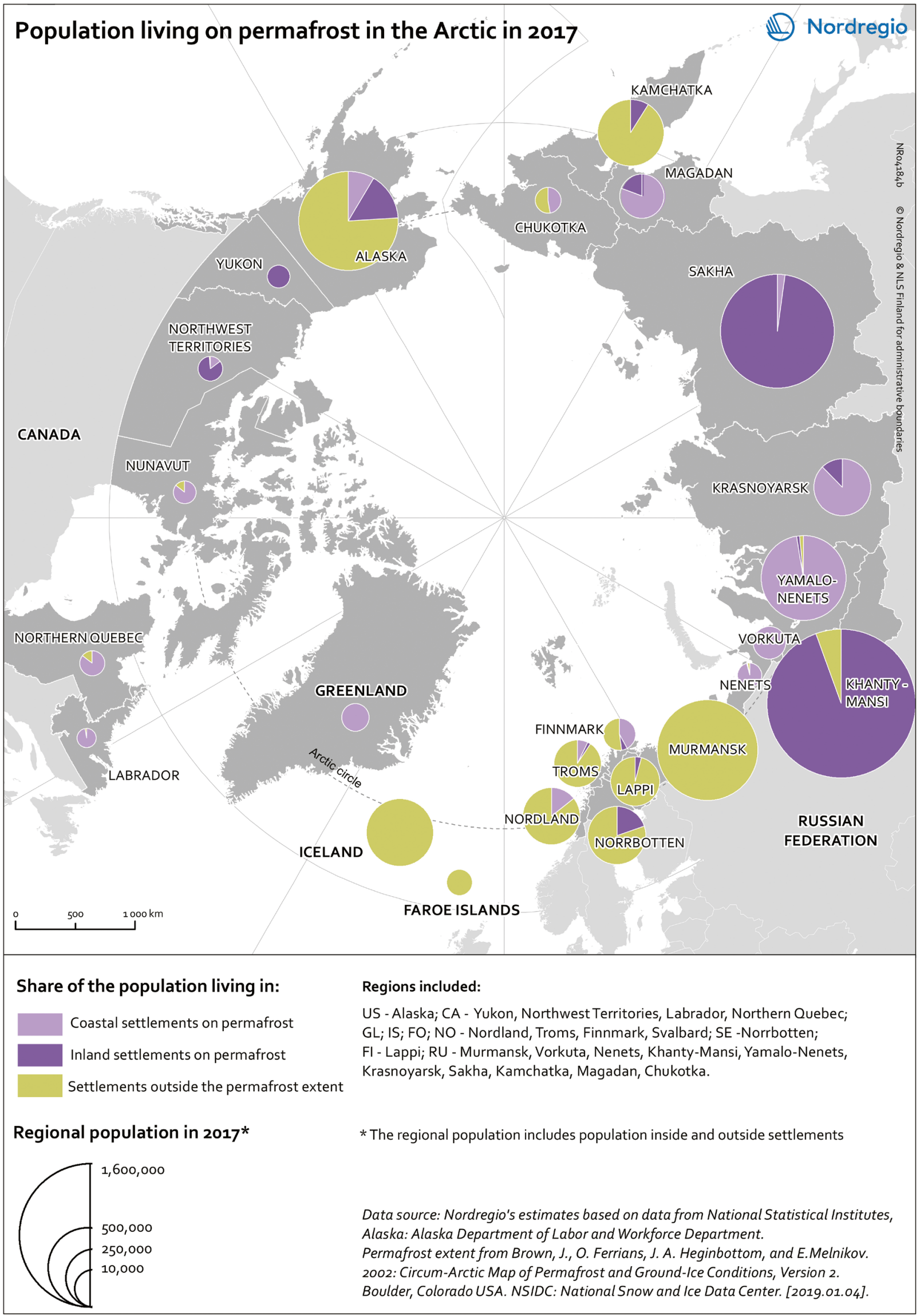

Map 5-6: Population living on permafrost in the Arctic 


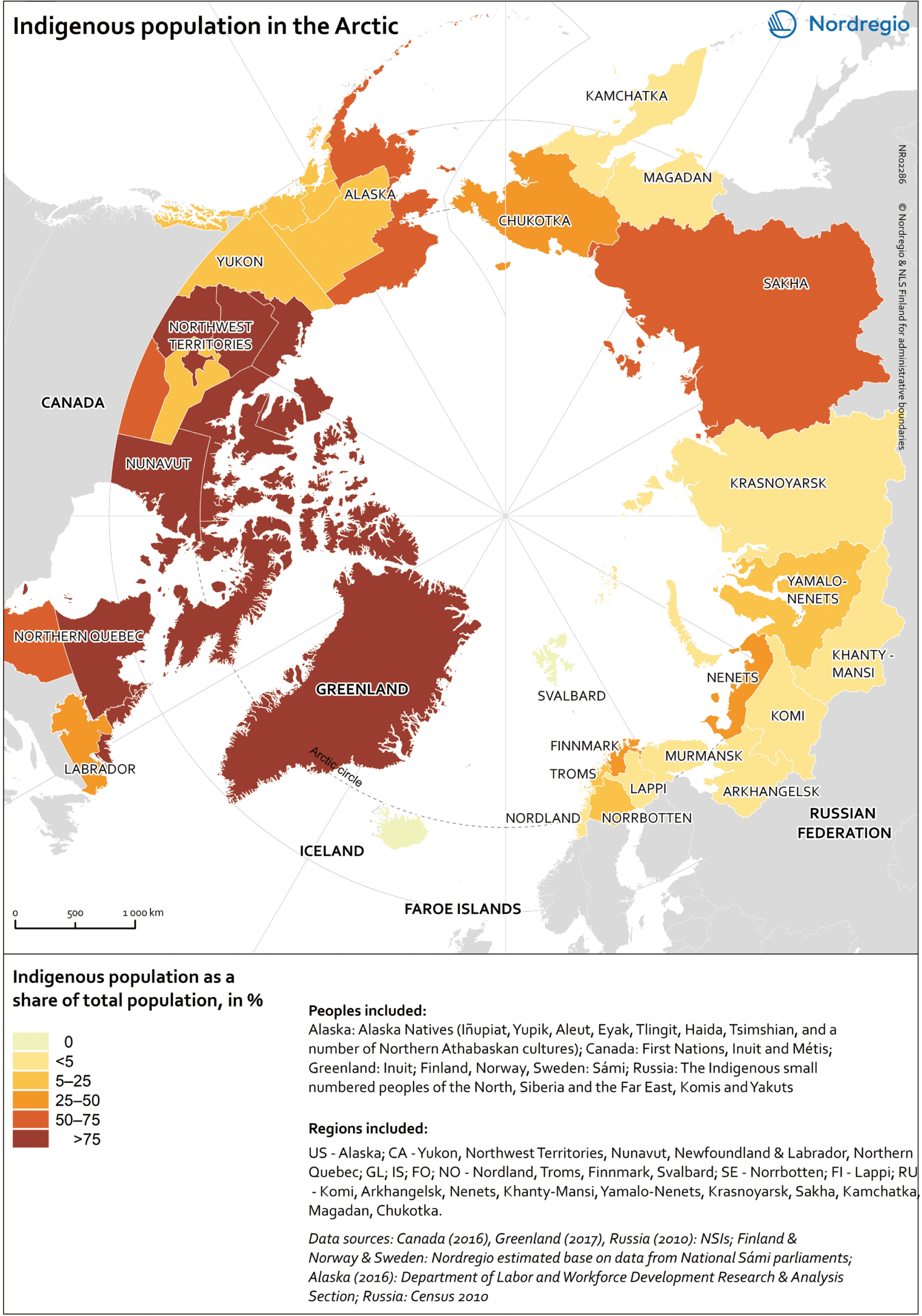

Map 5-7: Indigenous population in the Arctic. 


\subsection{Population change}

There is great variation across the Arctic region in terms of population size, growth rates and structure of settlements, as well as patterns in fertility, epidemiology and migration. There are also significant demographic differences between indigenous and non-indigenous populations. Across the Arctic, there has been a general trend towards the concentration of populations into larger urban centres and a decline in smaller settlements.

For any country or region, two processes underlie population change: natural change, which is the difference between the number of births and deaths; and net migration, which is the difference between people migrating to a region and those leaving. Alaska (USA) and most of the regions in the Canadian Arctic have experienced significant population growth in the past decades. In the Nordic regions, the population of Iceland has also grown significantly. The populations of Greenland and the Faroe Islands, on the other hand, have changed very little. The population has grown in all Norwegian Arctic regions, while there has been moderate overall growth in Swedish and Finnish Arctic regions, with a decline in some. The population of the Russian Arctic has continued its postSoviet contraction, with ongoing decline in all but two regions.

\section{Arctic population change at regional level}

Since 1990, the population of Alaska (USA) has grown by one-third thanks to a large natural increase and only moderate outmigration (Table 5-1). The population in the three Canadian northern territories has continued to grow. Since 2001, the population of the Northwest Territories has grown by $9.2 \%$, mostly due to a natural increase, as net migration was close to zero. The population of Yukon increased by $29.1 \%$ between 1991 and 2016, due to a natural increase and net migration in roughly equal measure. Of the three, Nunavut showed the highest growth $-41 \%$ since 2000 . This is due to a natural increase, in the form of higher fertility rates and a younger population.

The population of Iceland has grown considerably - by $37.3 \%$ - since 1990 . In recent years, migration has made a significant contribution to population growth. Like in many other Arctic regions, migration in Iceland fluctuates considerably. In 2013, however, net migration became positive and has increased every year since.

The population of Greenland has remained remarkably constant, at around 55,500. This stability is due to a balance between an increase in births and positive net outmigration.

The Faroe Islands have experienced moderate population growth of $5.7 \%$ since 1990 , with a

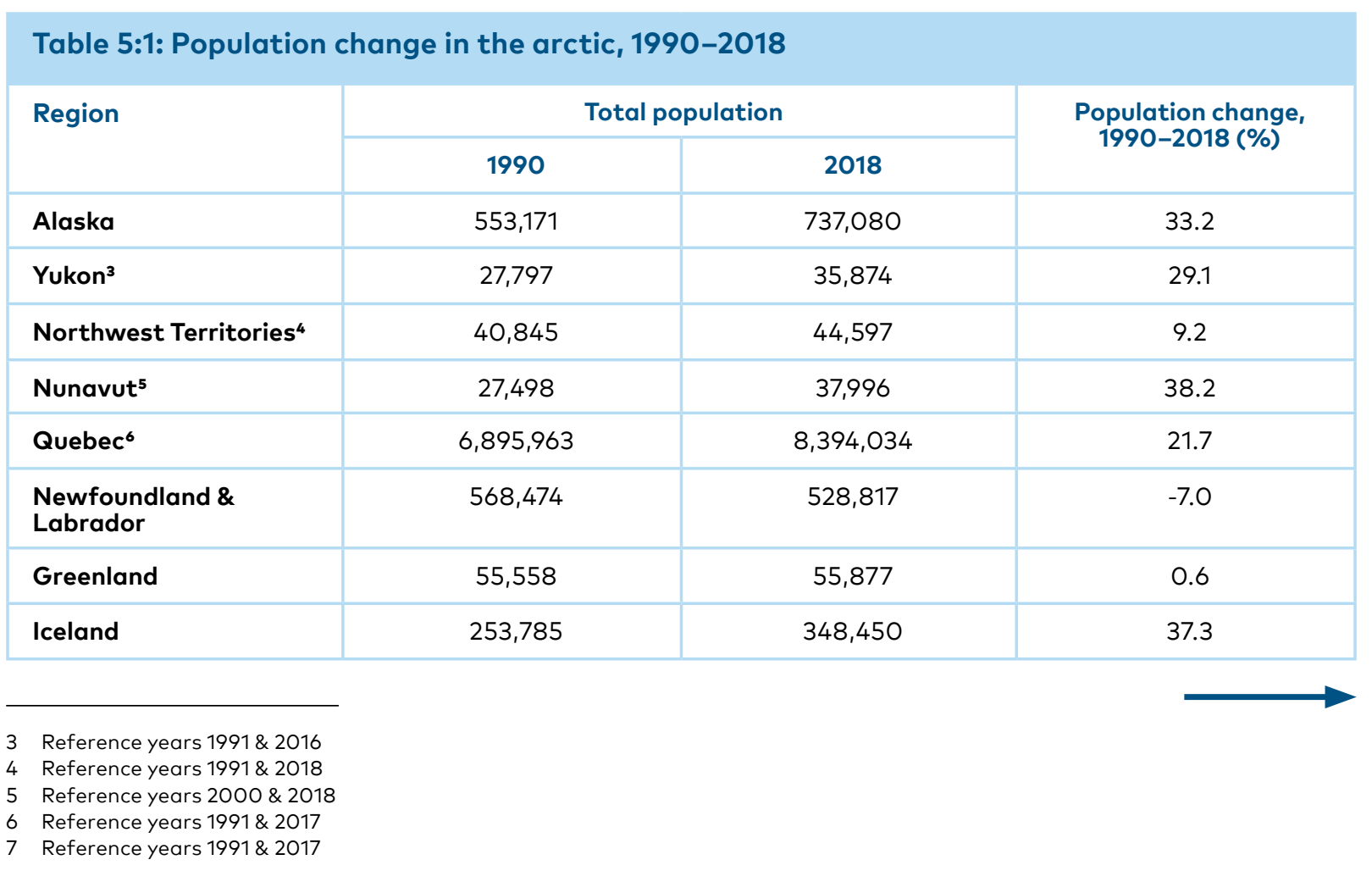




\begin{tabular}{|l|c|c|c|}
\hline Faroe Islands & 47,773 & 50,498 & 5.7 \\
\hline Nordland & 239,532 & 243,335 & 1.6 \\
\hline Troms & 146,594 & 166,499 & 13.6 \\
\hline Finnmark & 74,148 & 76,167 & -39.0 \\
\hline Svalbard & 3,532 & 2,152 & -4.4 \\
\hline Norrbotten & 262,838 & 251,295 & -10.4 \\
\hline Lappi & 199,973 & 179,223 & -36.5 \\
\hline Murmansk & $1,191,468$ & 757,000 & -26.0 \\
\hline Arkhangelsk & $1,575,502$ & $1,166,000$ & -31.9 \\
\hline Komi & $1,248,891$ & 850,000 & -15.4 \\
\hline Nenets & 51,993 & 44,000 & 29.9 \\
\hline Khanty-Mansi & $1,267,030$ & $1,646,000$ & 9.6 \\
\hline Yamalo-Nenets & 489,161 & 536,000 & -33.6 \\
\hline Taymyr & 51,867 & 34,432 & -32.3 \\
\hline Evenki & 24,005 & 16,253 & -13.4 \\
\hline Sakha & $1,111,480$ & 963,000 & -62.6 \\
\hline Magadan & 390,276 & 146,000 & -33.9 \\
\hline Kamchatka & 476,911 & 315,000 & -50.1 \\
\hline Koryak ${ }^{10} 11$ & 37,622 & 18,759 & \\
\hline Chukotka & 162,135 & 50,000 & \\
\hline & & & \\
\hline & & 19.2 & \\
\hline
\end{tabular}

similar pattern of natural increase to Greenland, although not quite offset by net outmigration.

Since 1990, the population of Norway has increased by $25 \%$. The populations of the three Norwegian Arctic regions have also increased, but much more slowly: Nordland by $1.6 \%$, Troms by $13.6 \%$ and Finnmark by $2.7 \%$.

The population of Sweden has grown significantly since 1990 - by $19 \%$, of which one-quarter was due to natural increase and three-quarters to net immigration. However, the population of Norrbotten has declined by $4.4 \%$ since 1990 .

Since 1990, the population of Finland has increased by $11 \%$ due to roughly equal contributions of natural increase and net immigration. However,

8 Reference years 1990 and 2011

9 Reference years 1990 and 2011

10 Merged with Kamchatka in July 1, 2007

11 Reference years 1990 and 2011 the population in Lappi decreased by $10.4 \%$ due to outmigration.

As a consequence of the former Soviet Union's central planning system, Russian Arctic cities are much larger than those in other Arctic regions. The break-up of the Soviet Union, the transition to a market economy and the liberalisation of society led to significant demographic upheaval in the Russian Federation, including the Russian Arctic. As a result of adjusting to the new economic conditions, the Russian Arctic's population declined by $20 \%$ - almost a quarter of the population. Many settlements across the Russian Arctic were closed or abandoned as they became depopulated. The largest population decline was in the eastern Russian Arctic, where the population of Kamchatka declined by one third, Magadan by nearly two thirds and Chukotka by nearly $70 \%$. 


\section{Arctic population change at settlement level}

Map 5-8: Population change in the Arctic settlements 2000-2017 provides an overview of population change in settlements with 500 or more inhabitants during the period 2000 to 2017. Map 5-9: Population change in the Arctic settlements 2010-2017 provides a recent picture of population change in settlements with 500 inhabitants or more during the period 2010 to 2017 . The purple layer shows the extent of permafrost across the Arctic. Four zoomed-in maps show areas with high settlement density - Arctic Fennoscandia, Iceland, the Faroe Islands, and Alaska (USA).

In Alaska (USA), the population decline in small settlements located far from the two large cities - Anchorage and Fairbanks - is due to outmigration, which has cancelled out the positive natural population growth.

In the Canadian Arctic, most people live in a small number of settlements. In the Yukon, there are 25 settlements, but $70 \%$ of the population live in the largest, Whitehorse. In the Northwest Territories, there are 33 settlements, but $48 \%$ of the population live in Yellowknife. Nunavut, which has 25 settlements, has a deliberate policy of relocating public-sector jobs to smaller settlements outside the capital of lqaluit, where only $21 \%$ of the population live.

The population of Greenland $(55,877$ as of 1 January 2018) live in 89 localities, including 17 towns, 54 settlements, five farms and five stations. Nearly one-third of the population live in the capital, Nuuk.

In the Faroe Islands, about $40 \%$ of the population reside in the capital, Torshavn. The rest live in smaller coastal settlements on the 16 (of 18) inhabited islands. The government has long had a policy of connecting all settlements to the national road system via a series of bridges and undersea tunnels, to ensure links between populations and reduce population decline in remote villages.

The Arctic regions of Norway, Sweden and Finland have larger populations. Most of the smaller settlements in Arctic Fennoscandia witnessed a population decline between 2000 and 2017, except in Norway. The dominant pattern in Fennoscandia is population growth in larger settlements, and population decline in the surrounding smaller settlements. A similar pattern is observed in the other Nordic Arctic regions - Iceland, Greenland and the Faroe Islands. New inhabitants from both domestic and international locations tend to set- tle in the capitals (Reykjavik, Nuuk, and Torshavn) and regional centres, whereas sparsely populated areas are becoming less attractive to incomers.

In the Russian Arctic, the regions can be divided into the oil and gas areas of Khanty-Mansi and Yamal-Nenets, among others. The population is growing in these resource-rich areas, but declining slowly in others. Over $75 \%$ of the settlements have been declining since 2000 , mainly as a result of outmigration.

\section{Arctic population change by components at sub-regional level}

The two components of population change are natural change and net migration. Map 5-10 shows the total population change in these two components at sub-regional level in the Arctic between 2013 and 2017.

There are large differences in the population change by component at sub-regional level. In Alaska (USA), the total population growth in the growing sub-regions was due to natural population increase. In the sub-regions experiencing a population decline, outmigration was a strong driver. Most sub-regions in the Canadian Arctic witnessed population growth between 2013 and 2017 due to a positive natural change. The exceptions are observed in Region 1 to Region 5 in the Northwest Territories, as well as in Labrador, where the population declined due to negative net migration. All sub-regions in Alaska (USA) and the Canadian Arctic had a positive average natural change rate, except for Haines Borough in Alaska (USA). In Greenland, all sub-regions experienced natural population growth and outmigration flows during the five-year period. Outmigration offset natural growth in Qeqqata, Kujalleq, and Sermersooq. The Nordic Arctic sub-regions experienced unprecedented inflows of migrants as well as the depopulation of rural areas. Negative natural population change was primarily witnessed in sub-regions in Norrbotten (Sweden) and Lappi (Finland). Substantial outmigration flows have contributed to the predominant pattern of population decline in sub-regions in the Russian Arctic. In addition, a natural population decline was observed in sub-regions of Murmansk, Magadan, Chukotka, and Kamchatka. On the other hand, population growth has occurred primarily in urban areas in Khanty-Mansi, Sakha (especially around the regional capital, Yakutsk) and Yamalo-Nenets. 


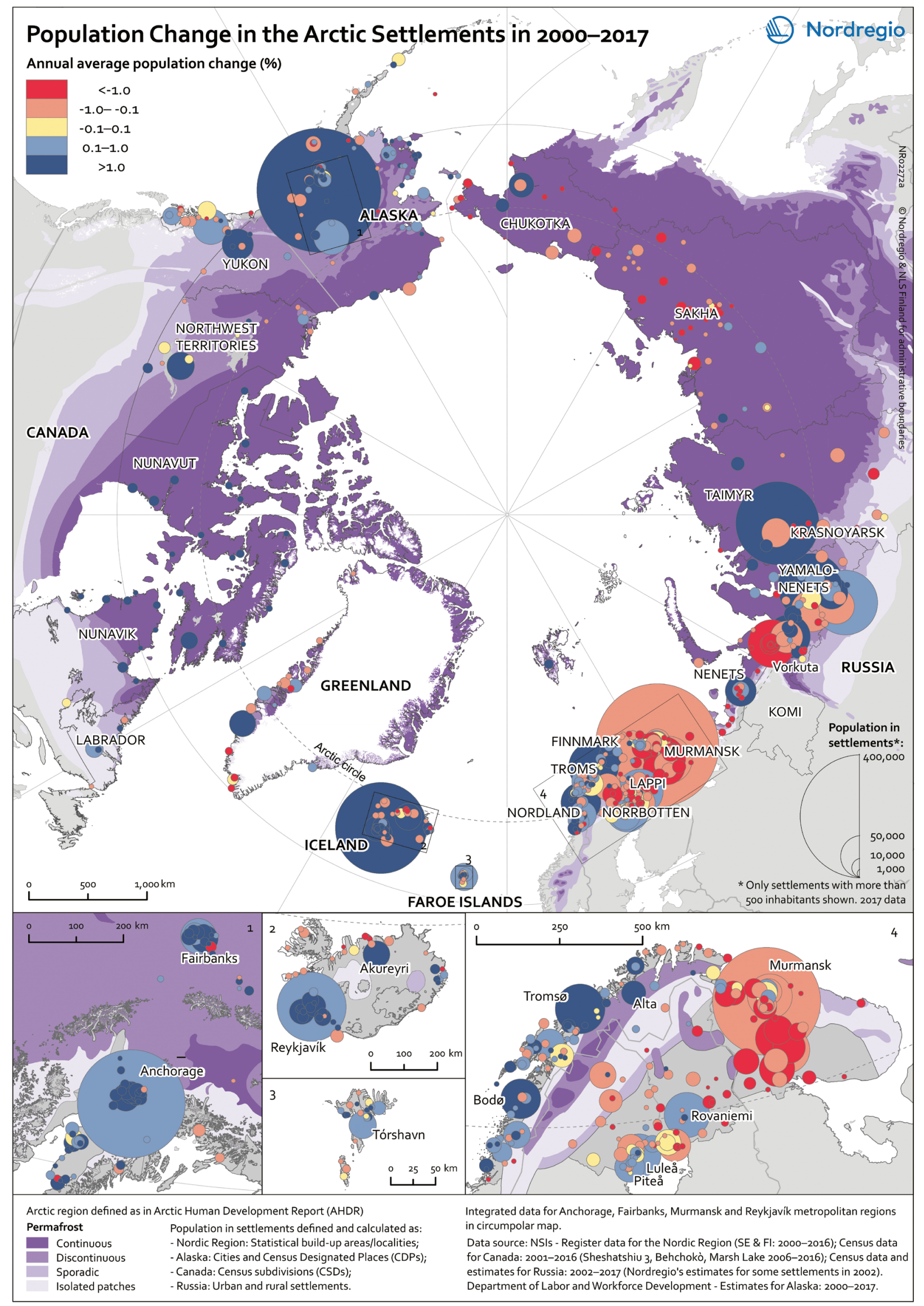

Map 5-8: Population change in the Arctic settlements 2000-2017. 


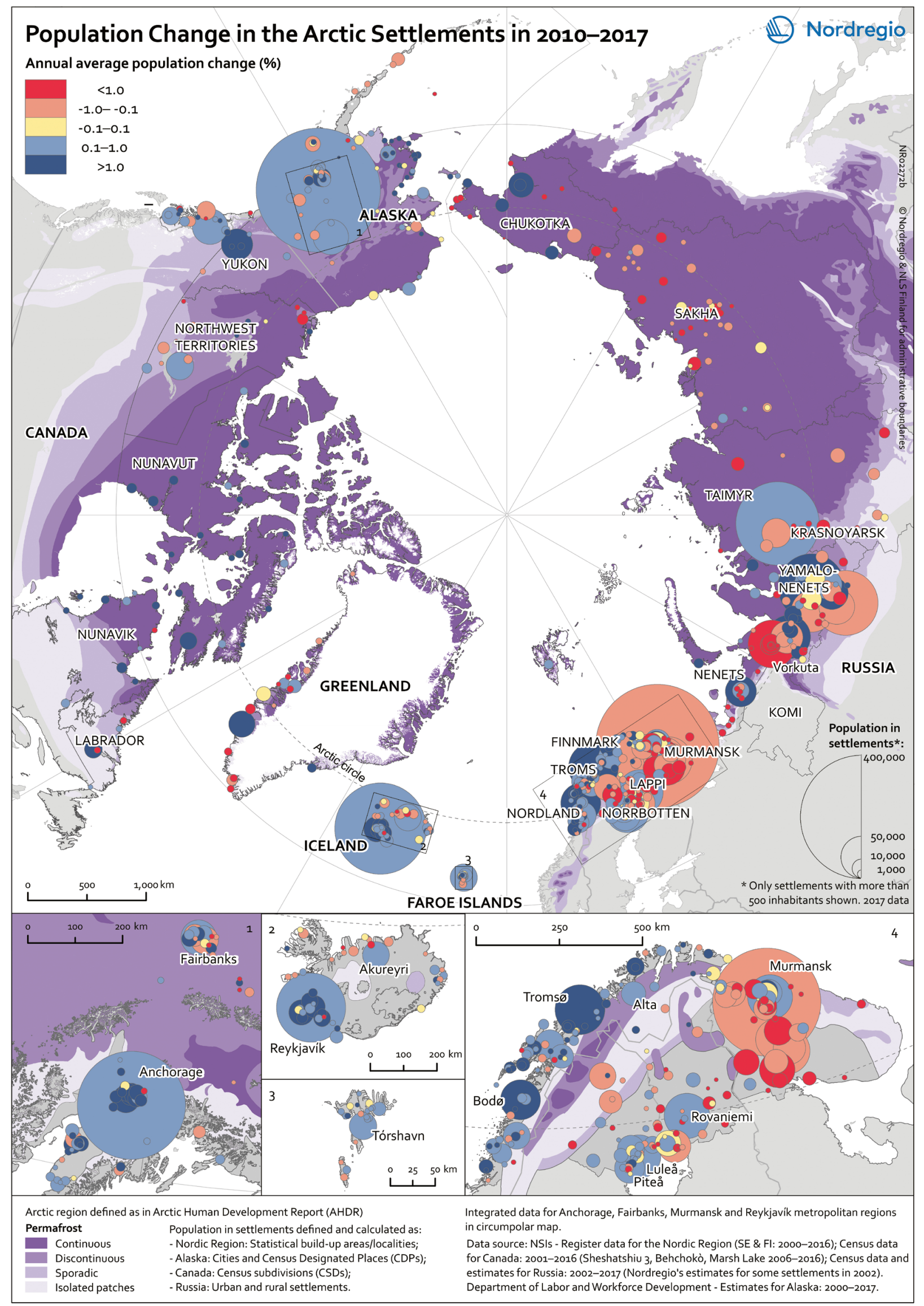

Map 5-9: Population change in the Arctic settlements: 2010-2017. 


\section{Component 1: Natural population change}

Maps 5-11 to 5-16 illustrate the indicators that explain natural population change. Natural population change is the difference between the number of births and the number of deaths. However, the pace of this change is influenced by other factors, e.g. life expectancy, infant mortality rate, fertility rate and different causes of death. The age structure of the different populations is also a key factor, which determines levels of natural increase (or decrease). Some of these indicators are also illustrated with maps in this subchapter.

Between 2013 and 2017, the average number of live births was 16.6 per 1,000 inhabitants, while the average number of deaths was 8.1. Based on these different figures, the annual average natural population change was therefore $0.66 \%$ during that period. The natural population change was particularly positive in the Canadian Arctic, Alaska (USA) and Greenland, as well as in Yamalo-Nenets, Khanty-Mansi and Sakha (Russian Federation). Natural population decline was the largest in the Nordic Arctic, as well as in Murmansk, Magadan and Kamchatka (Russian Federation).

The number of deaths per 1,000 live births of children under the age of one year is commonly referred to as the infant mortality rate (see Map 5-14: Infant mortality rate in the Arctic 2012-2016). In Chukotka (Russian Federation) and Nunavut (Canada), infant mortality was notably higher than the overall Arctic average, with about 20 infant deaths per 1,000 live births. The regions with the lowest infant mortality rate were Troms (Norway, 1.8), Iceland (2.0), Lapland (Finland, 2.0), Norrbotten (Sweden, 2.5), and the Yukon (Canada, 2.9).

As one of the UN Sustainable Development indicators for good health and well-being, life expectancy at birth measures the general health status of a population (see Map 5-15: Life expectancy at birth). At the national level, life expectancy is highly correlated with national income indicators, such as GDP per capita. Across the Arctic region as a whole, life expectancy in 2012-2016 was 74.7 years. Regional differences are partly due to specific lifestyles, but also the local environment, as well as the politics and institutions that influence the local economy, access to local services (including care), and general educational levels. The longest life expectancies were in Iceland (82.5 years), Quebec (82.2 years) (Canada) and Faroe Islands (82.1 years), as well as in Troms and Nordland (Norway), Norrbotten (Sweden), and Lapland (Finland). The shortest was in Chukotka (62.8 years) (Russian Federation). In general, life expectancy was shorter in the Russian Arctic than in the other Arctic regions due to high mortality rates among the working-age population. The Russian Arctic had much higher rates of deaths from external causes (including accidents, murders and suicide) than other countries. Moreover, there was a much bigger difference between male and female life expectancy in the Russian Arctic than in other Arctic regions.

Mental health disorders can lead to long-term disability, and the most dramatic manifestation of mental illness is suicide. Map 5-16: Cause of death by suicide shows the mortality due to suicide between 2012 and 2016 in the Arctic regions. Greenland had the highest suicide rate in the Arctic (78.6\%). Nunavut (Canada) and Chukotka (Russia) had relatively high suicide rates of over $50 \%$ during 2012-2016. The Faroe Islands had the lowest suicide rate, at $3.7 \%$.

\section{Component 2: Migration}

The Arctic had an annual average net migration rate of $-0.4 \%$ during the period 2013-2017. Map 5-17: Net migration rate shows net migration as a share of the total population at sub-regional level in the Arctic. There are significant differences between the Arctic sub-regions. Outmigration played a predominant role in Alaska (USA), the Northwest Territories, Northern Quebec and Labrador (Canada), Greenland, and the Russian Arctic. Conversely, in-migration was the major source of population increase in the Nordic Arctic subregions. Yukon and Nunavut (Canada) witnessed positive net migration rates. Across the Arctic, in-migration prevailed in sub-regions with larger urban centres, while sparsely populated areas, i.e. most settlements in the Arctic region experienced declining populations. 


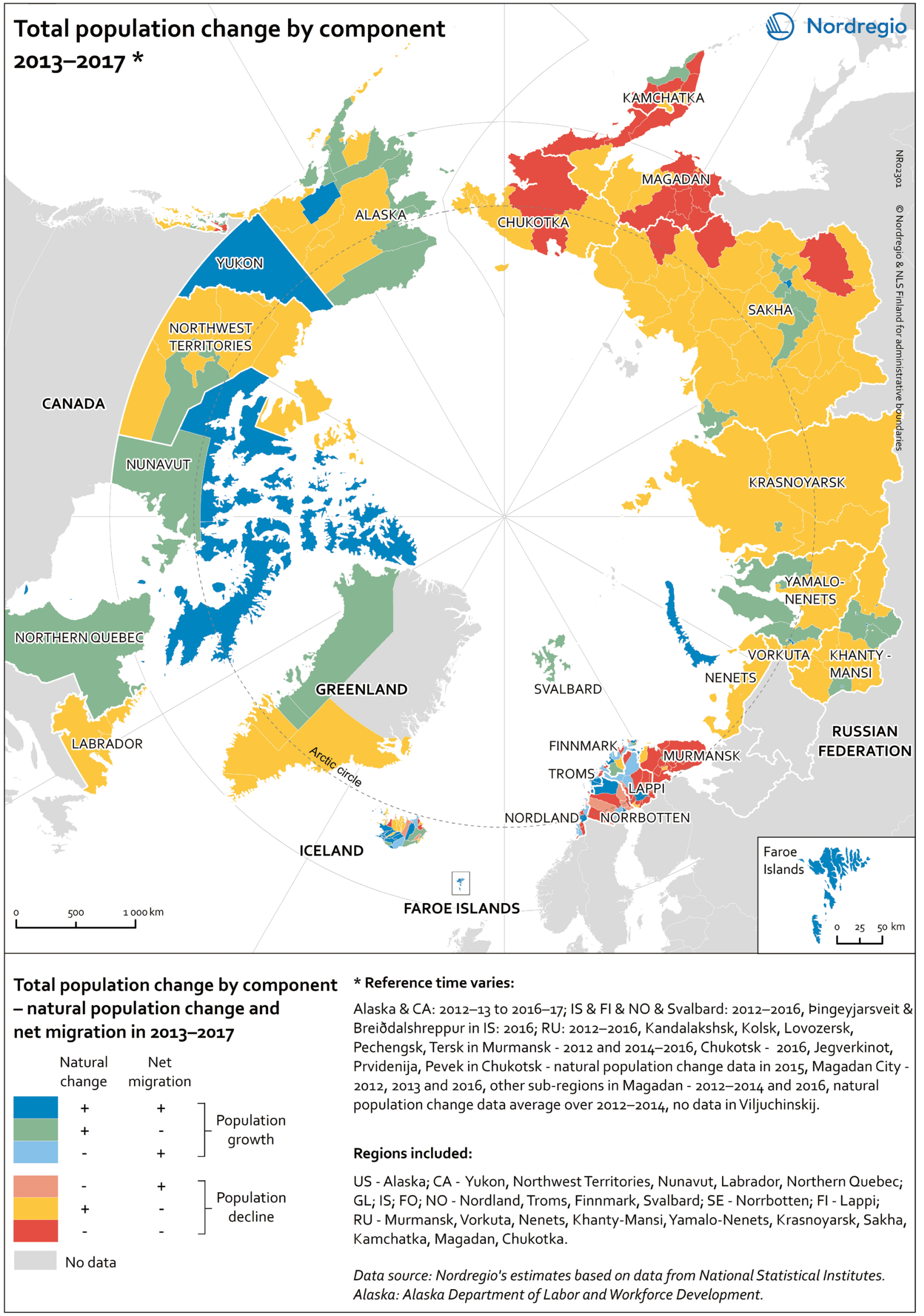

Map 5-10: total population change by components 2013-2017. 


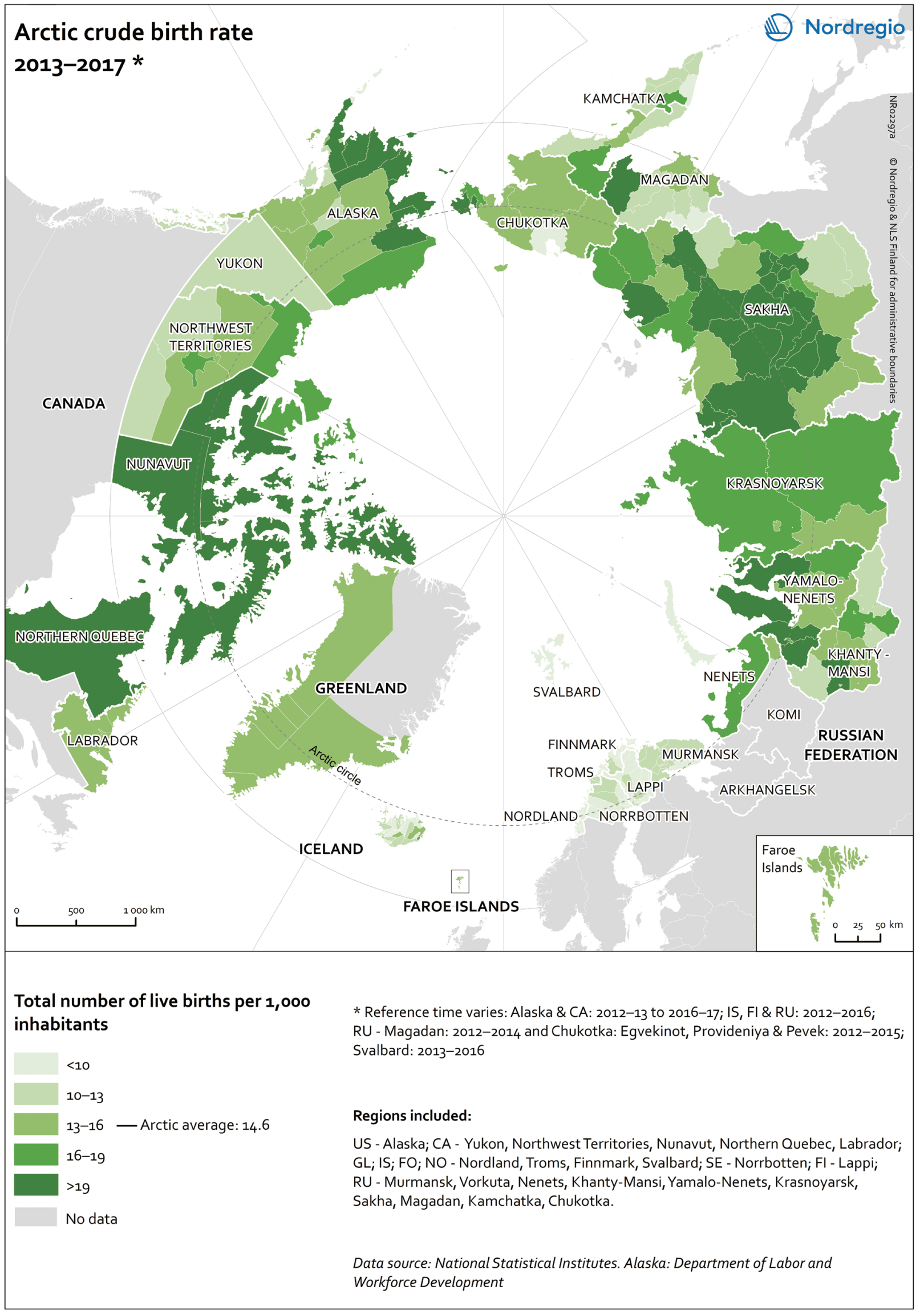

Map 5-11: Arctic crude birth rate 2013-2017. 


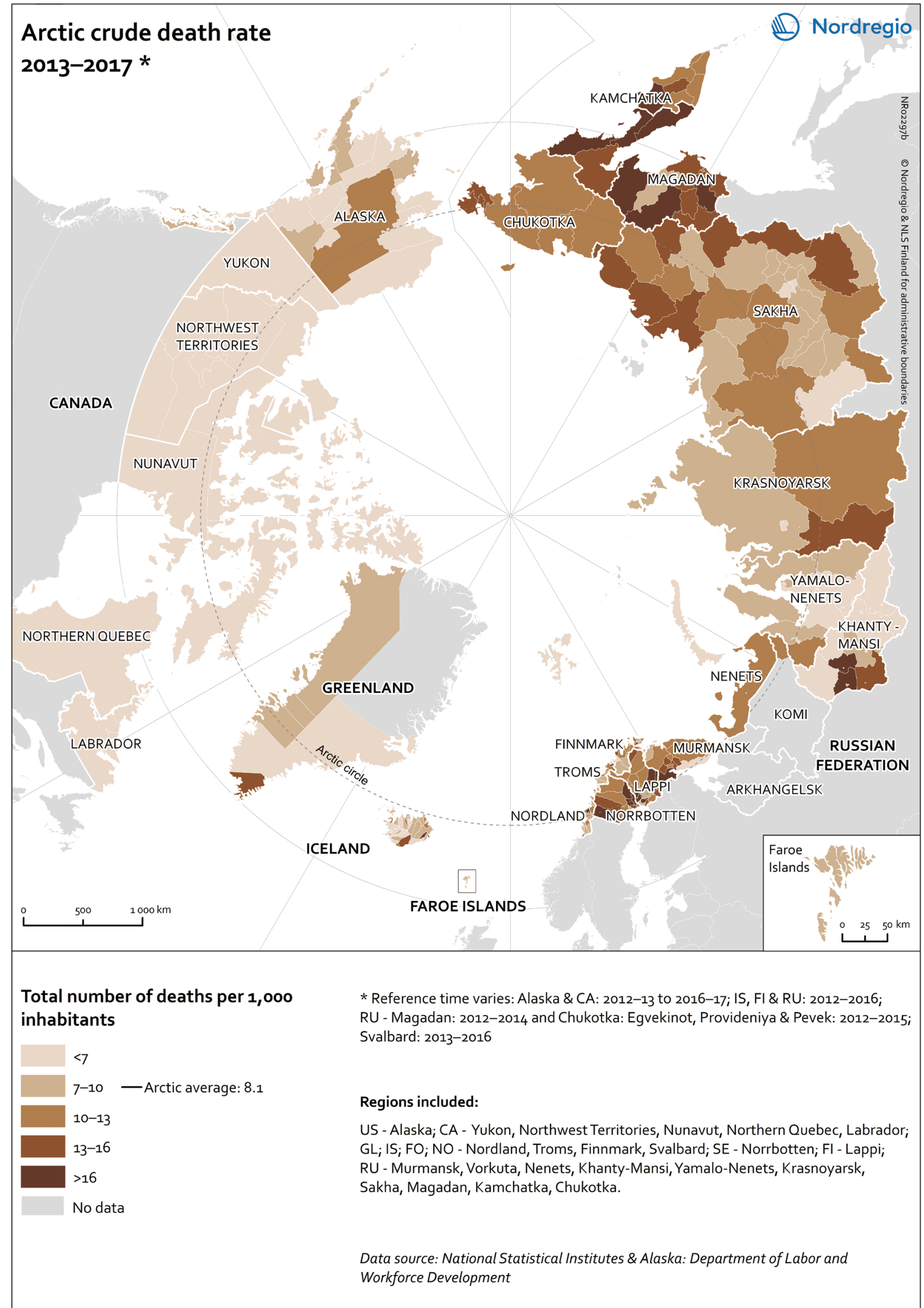

Map 5-12: arctic crude death rate 2013-2017. 


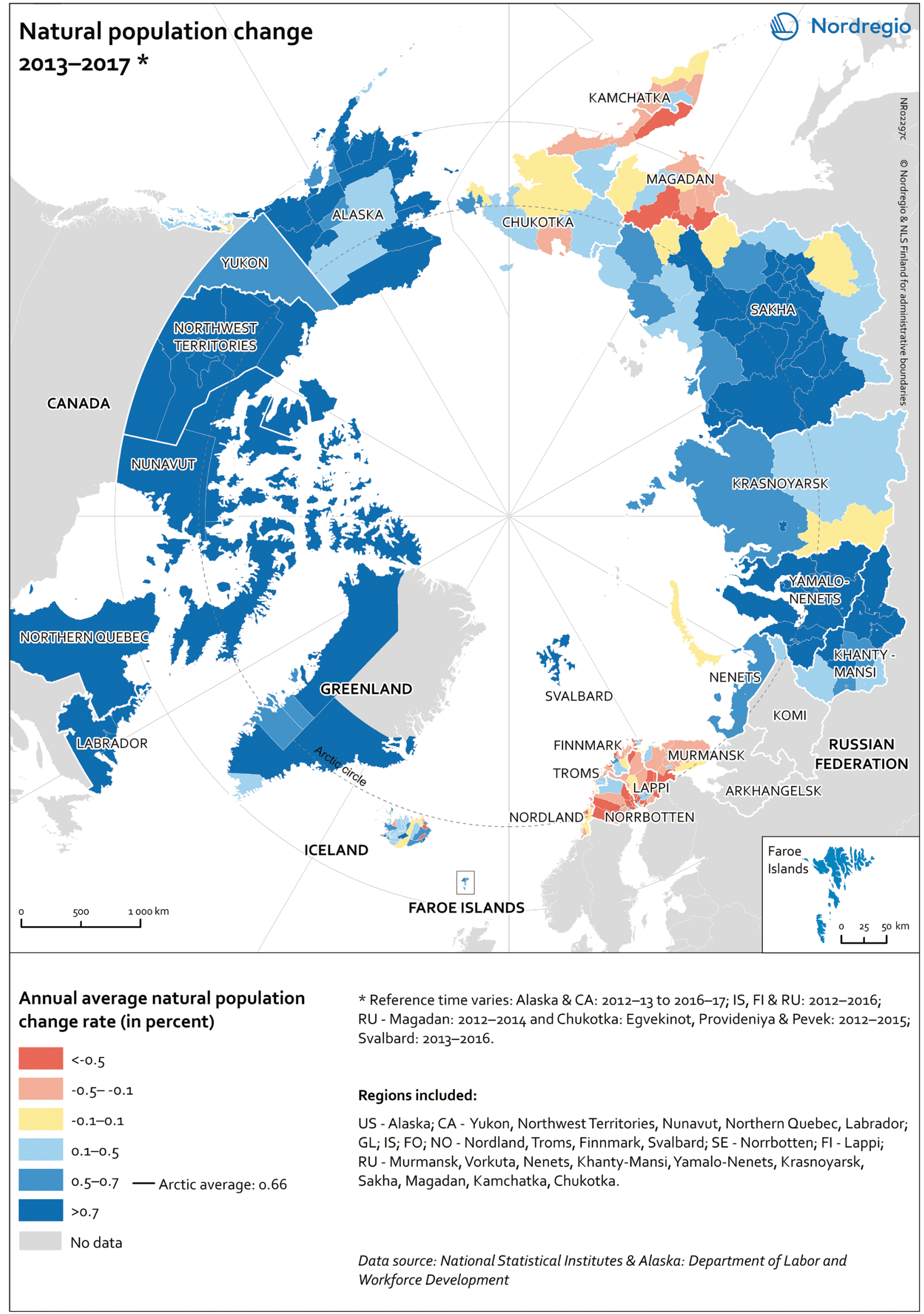

Map 5-13: Natural population change in the arctic 2013-2017. 


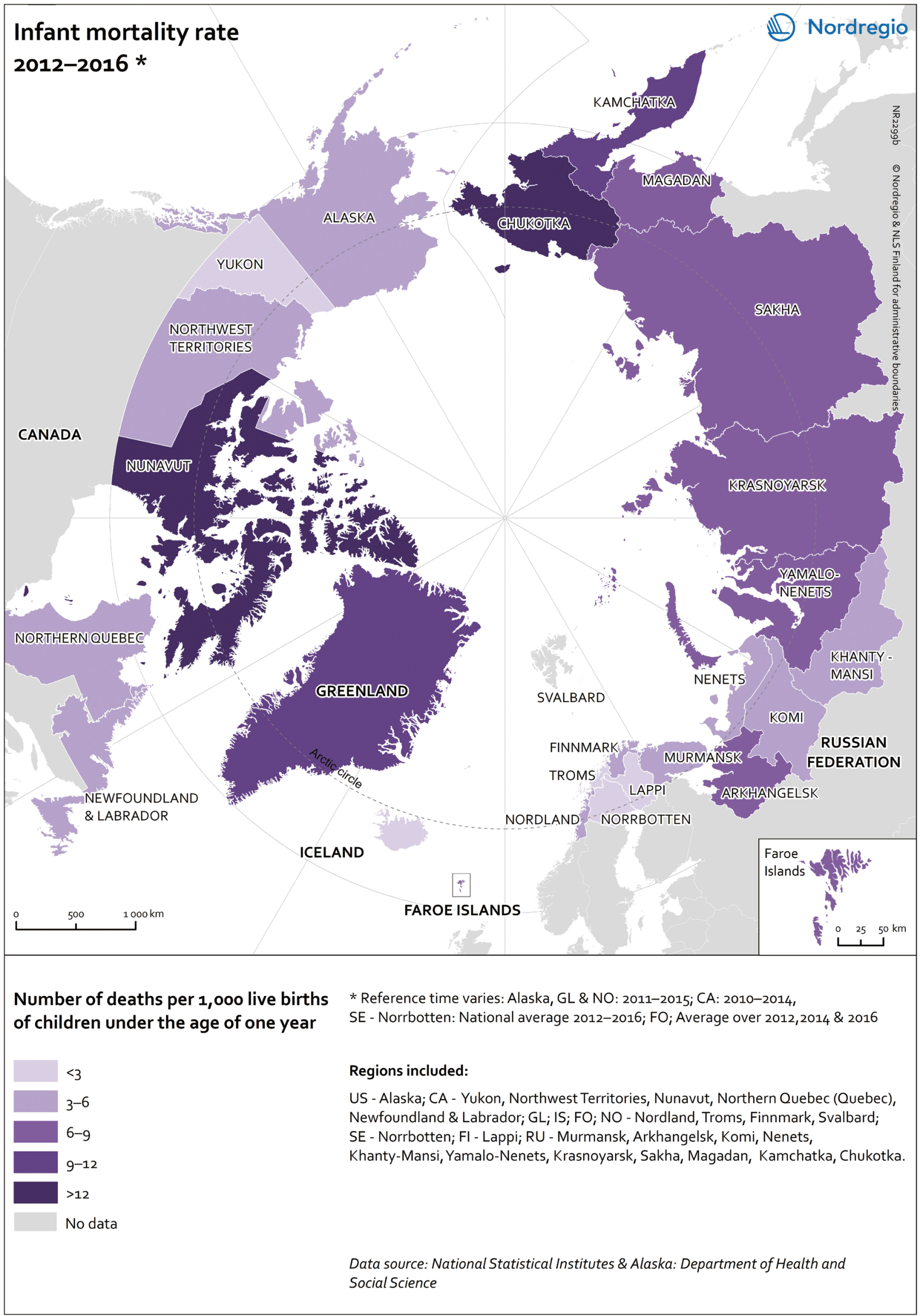

Map 5-14: Infant mortality rate in the arctic 2012-2016. 


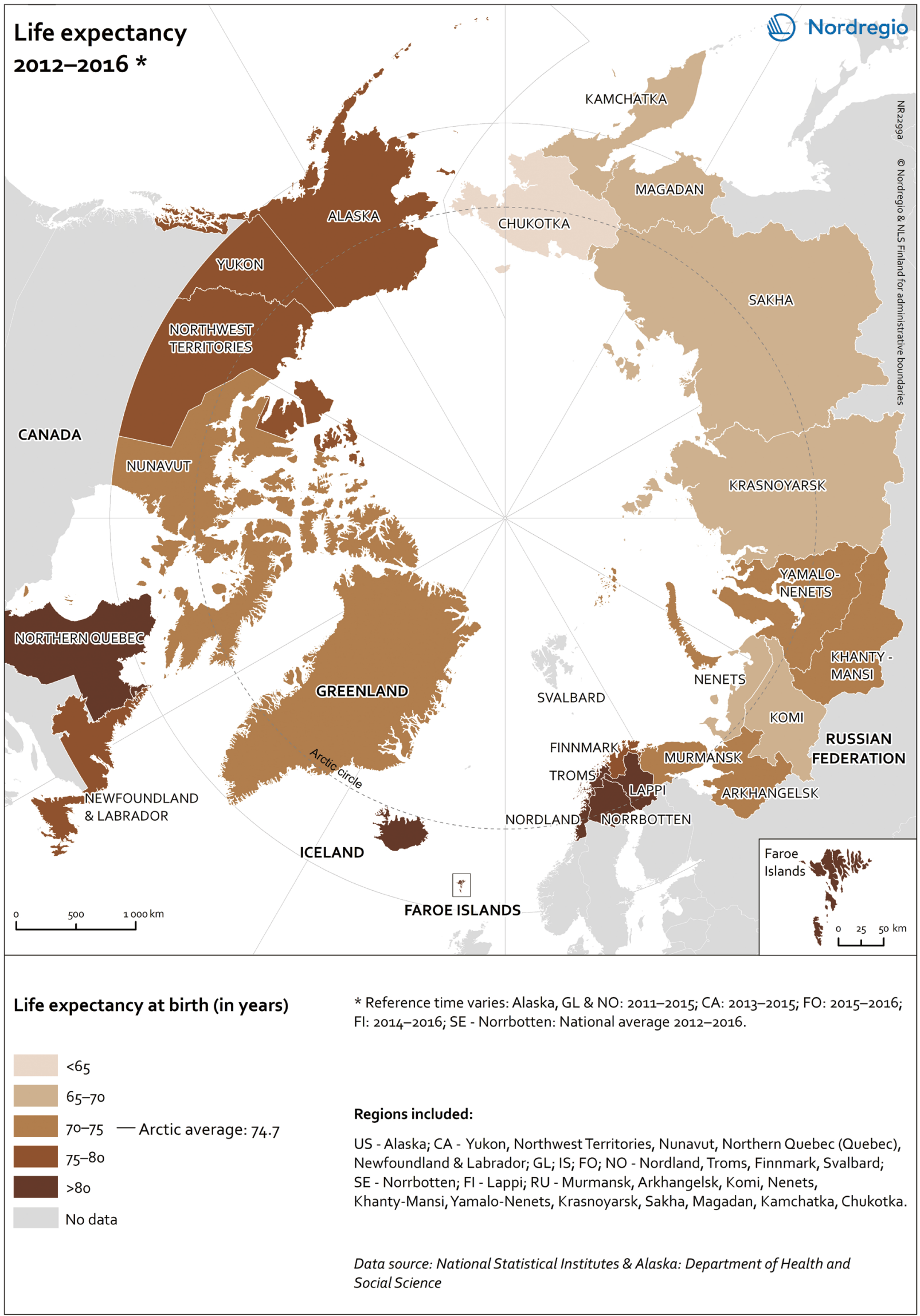

Map 5-15: Life expectancy at birth in the arctic 2012-2016. 


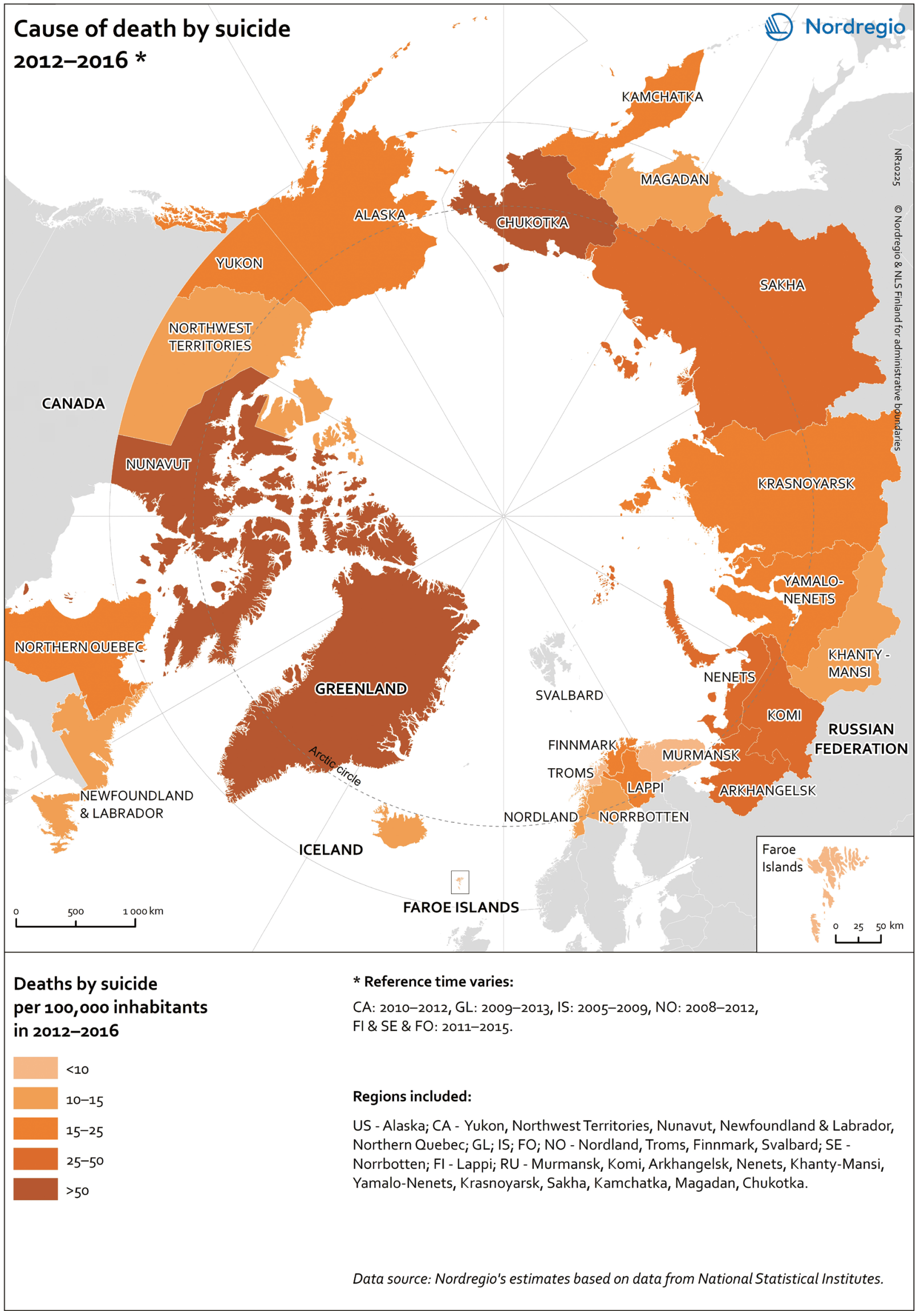

Map 5-16: Cause of death by suicide in the arctic 2012-2016. 




Map 5-17: Net migration rate in the arctic 2013-2017. 


\subsection{Population structure}

Maps 5-18 to 5-23 illustrate population structure in 2017 by different age groups, as well as the gender balance across the Arctic at regional and subregional level. The age groups are divided and classified as follows: young, youth, working-age and elderly people.

In the Arctic, $20.5 \%$ of the total population was aged 0-14. The highest shares were in Tazovsky District (34.4\%) and Yamalsky District (34.0\%) in Yamalo-Nenets (Russian Federation). Other subregions with a share of young people over $30 \%$ were Nunavut (Canada), Kulsivak Census Area (Alaska), and Sakha (Russian Federation). The sub-regions in which young people were the smallest share of the population (represented by yellow markers) were in the Nordic countries, the Aleutian Islands (Alaska), Novaya Zemlya and two subregions of Kamchatka (Russian Federation). Compared to the national averages, the population in the sub-regions was younger in Alaska (USA) and in the Canadian and Russian Arctic regions than in their respective states as a whole. In Arctic Finland, Norway and Sweden, the shares of young people were lower than the national averages.

The OECD and the United Nations define 'youth' as those aged 15 to 24. Map 3-19 depicts the share of youth in the Arctic region. Keewatin in Nunavut region (Canada) had the highest share of youth (18.8\%). The youth share was over $15 \%$ of the total population in Region 3 (17.5\%) in the Northwest territories, Northern Quebec (16.1\%) and the other two regions in Nunavut (Canada). Magadan (9.2\%), Arkhangelsk (9.4\%) and Komi (9.7\%) (Russian Federation) had the lowest youth shares of total population.

In the Arctic, the share of the working-age (1564 years) population was $69.8 \%$. The sub-regions with a share of working-age population lower than $60 \%$ were in the Nordic countries. High shares of working-age population were found in sub-regions in the Russian Federation, Svalbard (Norway) and the Aleutian Islands (Alaska). In the Russian Arctic, many sub-regions in the Chukotka region, urban sub-regions in Yamalo-Nenets and the city of Norilsk in Krasnoyarsk, among others, had a working- age share of over $75 \%$. The highest share of working-age population was in regions where a high proportion of employment is related to extracting natural resources, e.g. oil, gas and minerals. This is especially the case in the Russian Arctic regions. Generally speaking, the Arctic is characterised by a low share of elderly people (aged 65 and over) (9.7\%), especially in the sub-regions of YamaloNenets, Krasnoyarsk and Chukotka (Russian Federation), as well as Nunavut (Canada). Many Nordic sub-regions had a share of elderly people over 20\%, as did Haines Borough (Alaska).

Gender balance, illustrated as a female ratio of the total population, indicates a slightly predominant female population across the Arctic (average 104.5). However, there are large differences between sub-regions. In the Russian Federation, sub-regions in Komi, Arkhangelsk, Murmansk and Sakha had a female ratio in excess of 110 females per 100 males. The female ratio in the Russian Arctic compared to other Arctic countries was higher due to notable differences between females' and males' life expectancy. Other Arctic sub-regions in Alaska (USA), Canada, Greenland and the Nordic countries had a predominance of males. Pechengsky District (Russian Federation) and Sermersooq municipality (Greenland) were two of the subregions with more than 20,000 inhabitants with the highest male predominance. Fifty-five subregions in the Arctic had an equal gender balance (depicted in yellow).

The Arctic average for the female ratio in the working-age population was 99.6 - in other words, a gender balance. However, females were predominant among the working-age population in many sub-regions of the Russian Federation, as well as the Yukon in Canada. The level of female predominance was especially high in larger Russian Arctic cities (with populations of more than 200,000) such as Surgut in Khanty-Mansi (110), Yakutsk in Sakha (113), Murmansk (108) and Nizhnevartovsk in Khanty-Mansi (107). In all other regions, males were predominant, especially in Greenland, Norway, Sweden and Alaska (USA), where there were no sub-regions with female predominance within the working-age population. 


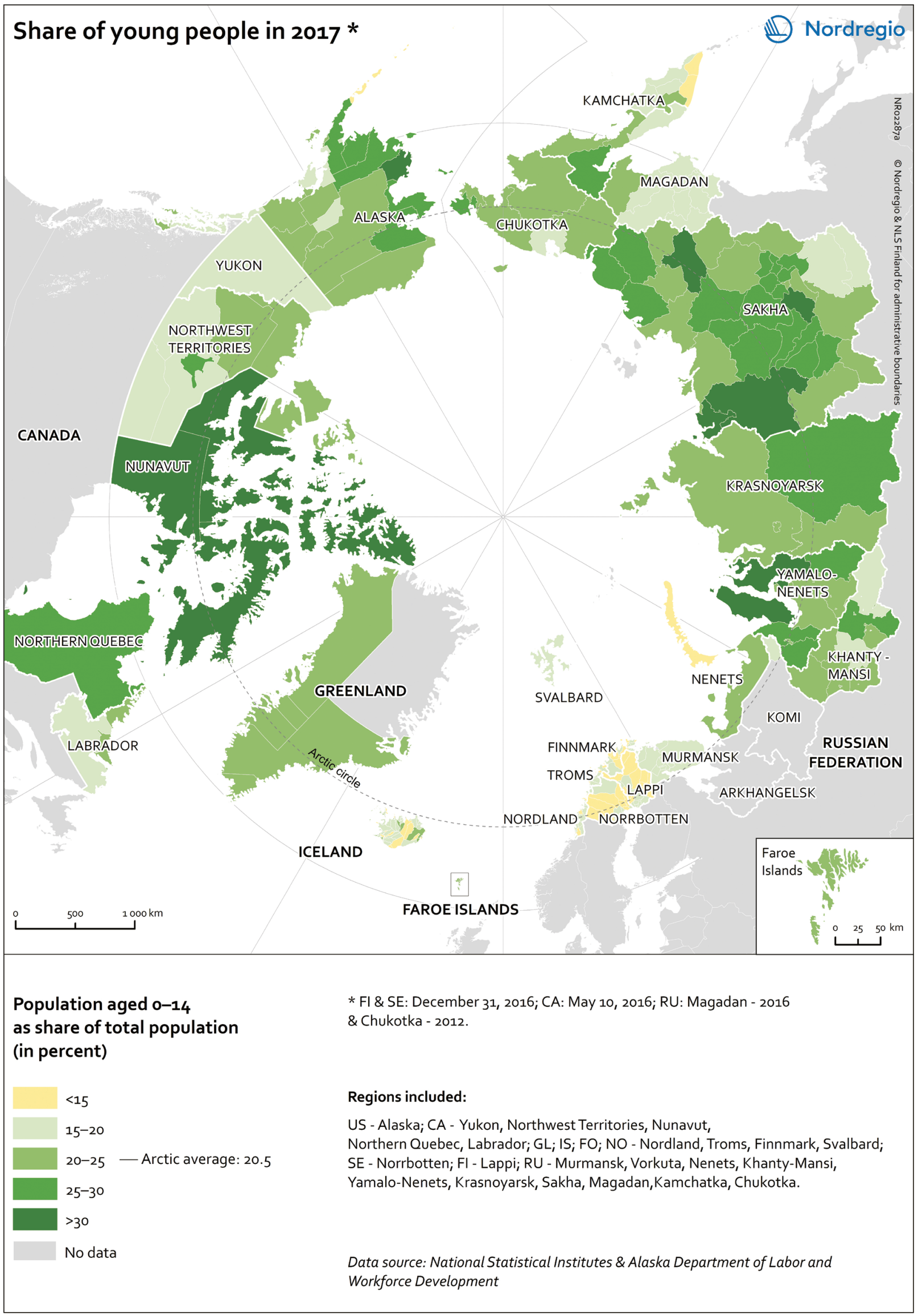

Map 5-18: Share of youth aged 0-14 in the arctic in 2017. 


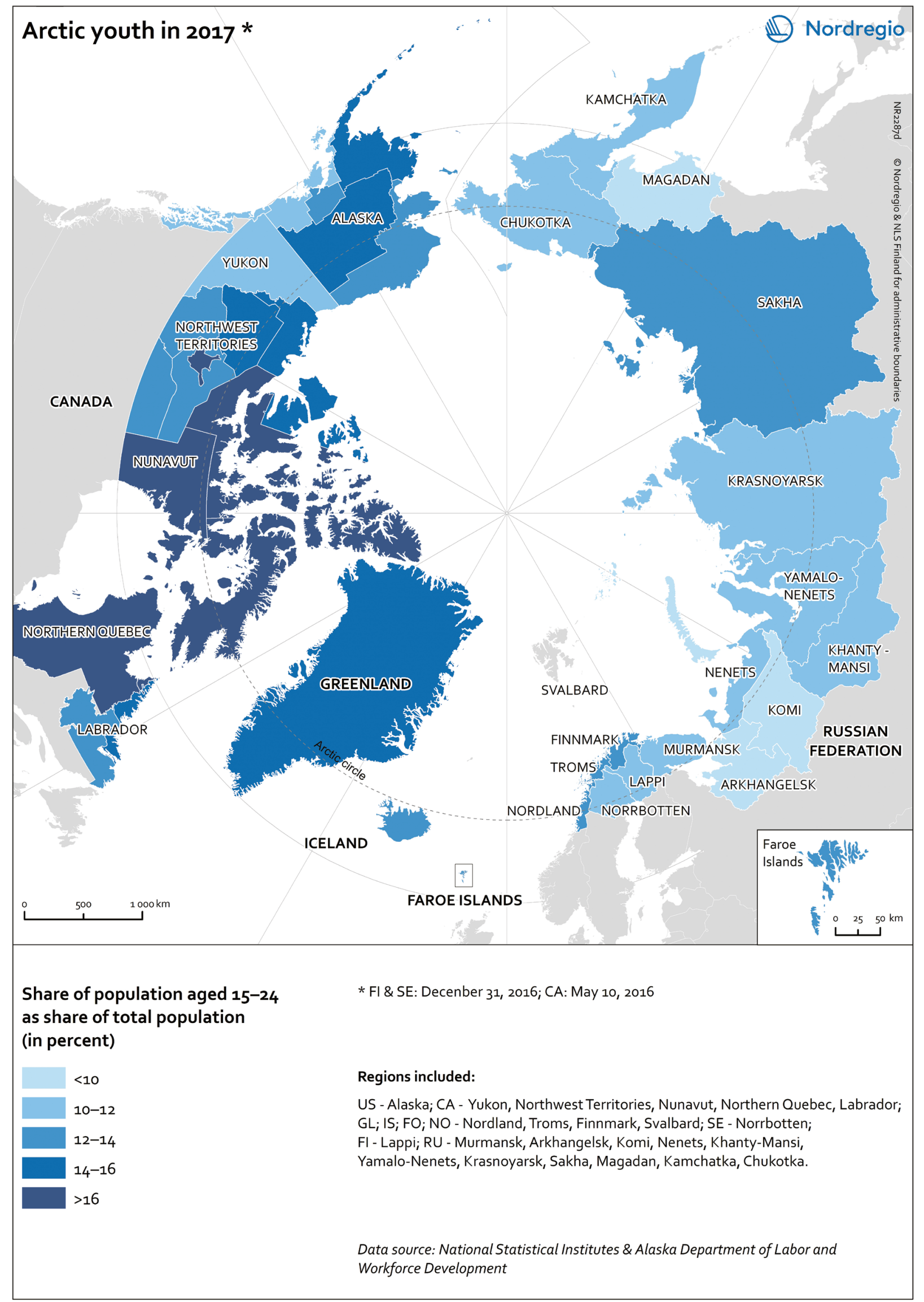

Map 5-19: Share of youth aged 15-24 in the Arctic in 2017. 


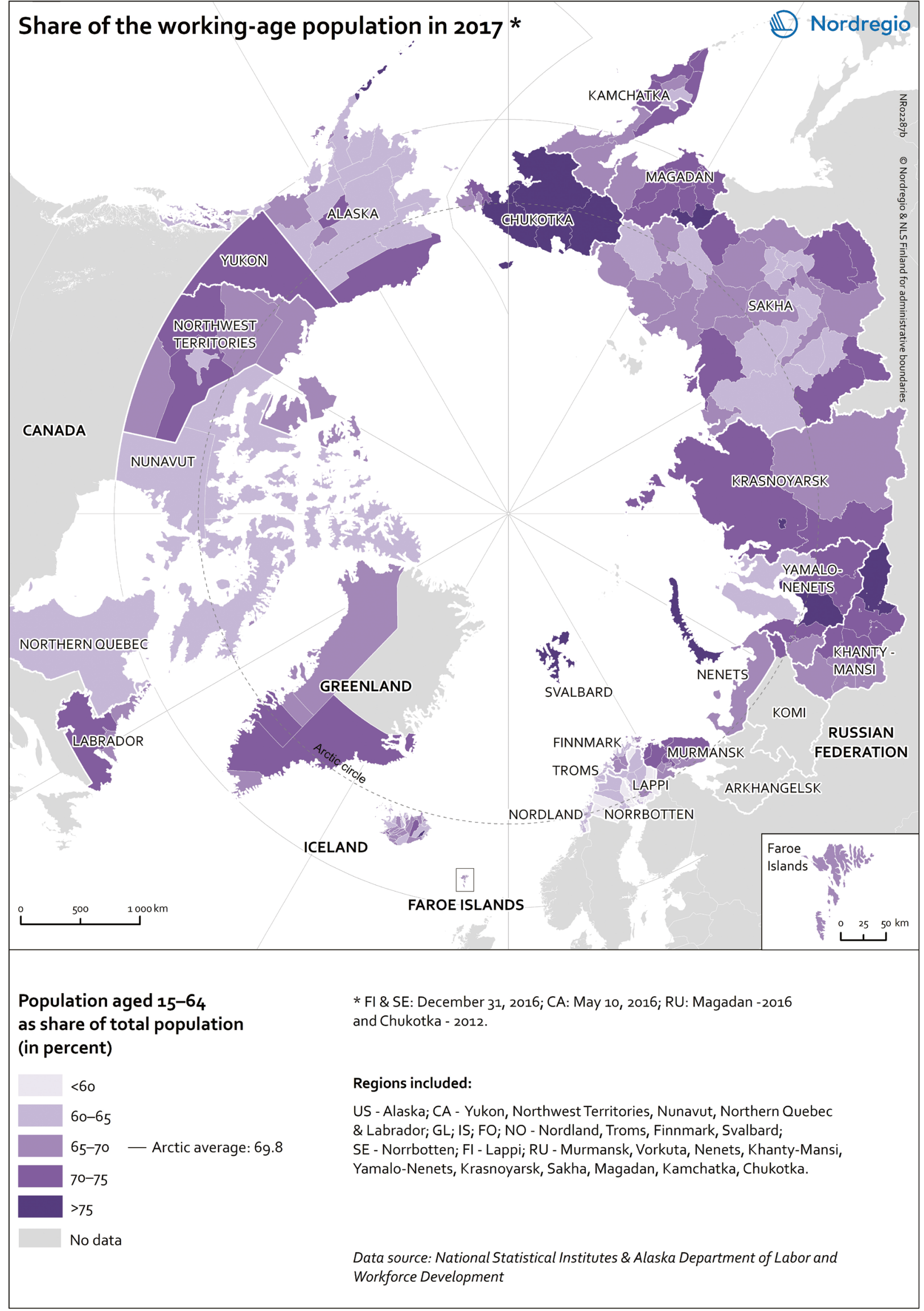

Map 5-20: Share of the working-age population in the Arctic in 2017. 


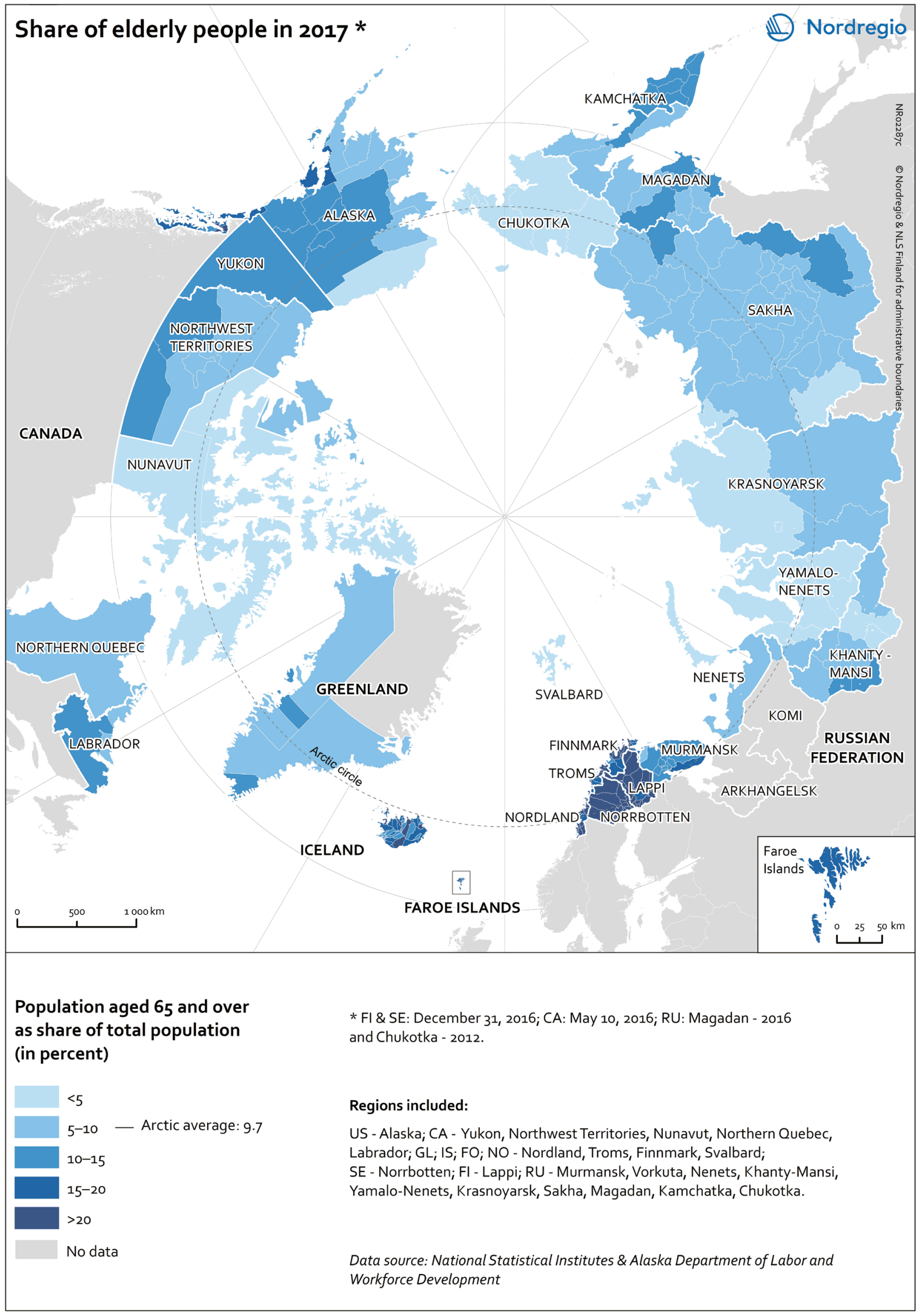

Map 5-21: Share of elderly people in the arctic in 2017. 


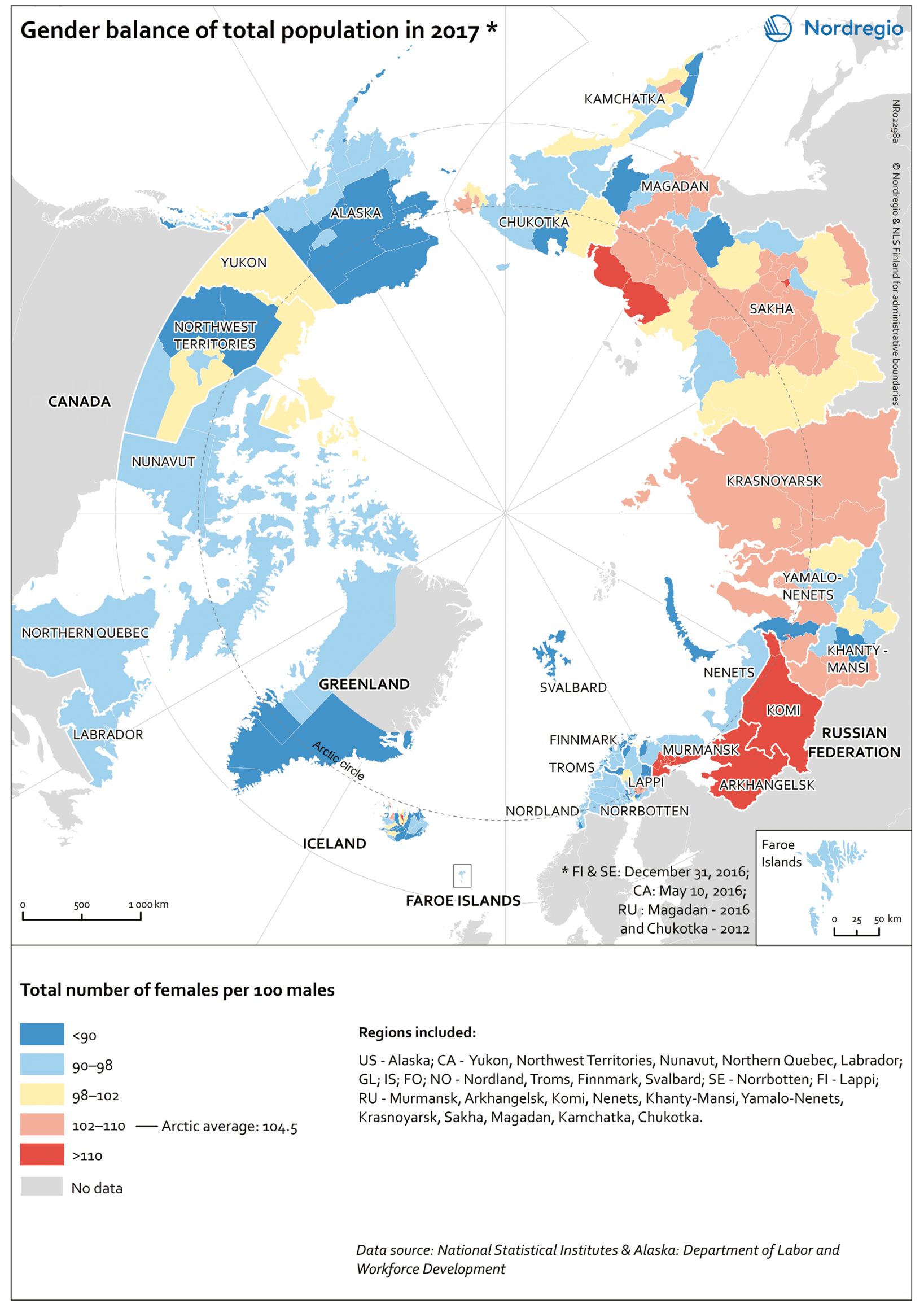

Map 5-22: Gender balance of total population in the arctic in 2017. 


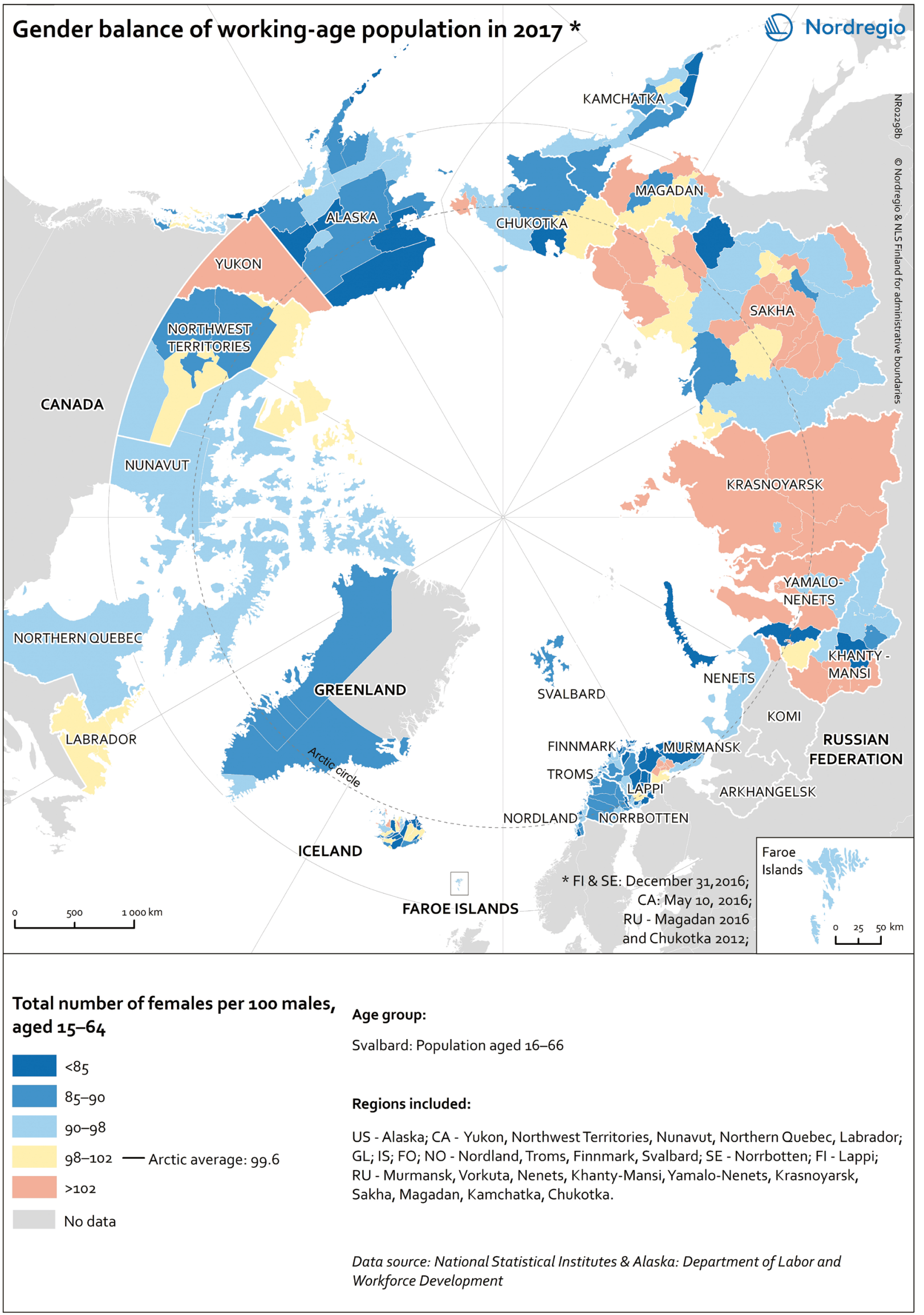

Map 5-23: Gender balance of the working-age population in the arctic in 2017. 


\section{Society and economy}

The maps illustrating societal and economic trends focus on education, the labour market and production in the Arctic regions. Education and labour market conditions are indicators of regional innovation and economic sustainability, which support efforts to make the Arctic regions attractive places for young people to work and study. Local educational opportunities and people with higher levels of educational attainment indicate the retention of knowledge, skills and competences acquired within the regions. Local business opportunities are more likely to grow in regions that have a skilled workforce and an innovative environment that supports new business ideas.

Most of the Arctic regions are characterised by a high level of economic dependence on natural resources, with several large-scale mining projects. Approximately $50 \%$ of those employed here work in the public sector, while $50 \%$ are employed in the private sector. Several Arctic regions have a higher disposable income per capita compared to the national average.

\subsection{Education}

Education is measured based on upper-secondary and tertiary educational attainment (maps 6-1 and 6-2). Among the working-age population, the number of individuals with upper-secondary education was highest in Alaska (USA) with over $90 \%$, followed by an attainment level of more than $80 \%$ in Yukon and Labrador (Canada), Norrbotten (Sweden) and Lappi (Finland). The lowest share of individuals with upper-secondary education was in Greenland (45.6\%), Chukotka (58.4\%) (Russian Federation) and Nunavut (59.1\%) (Canada).

Tertiary education corresponds to International Standard Classification of Education (ISCED) 2011 levels 5-8, i.e. a bachelor degree or equivalent, and all higher attainment levels. The regions with the highest share of population with a tertiary education were Troms (43.8\%) (Norway) and Iceland (42.5\%). All other Nordic Arctic regions, as well as Yukon (33.3\%) (Canada) and some regions in Alaska (USA), had a large share of highly educated people. Northern Quebec (Canada) had the lowest share of working-age population with a tertiary education (13.0\%).
Map 6-3 depicts higher educational institutions in the Arctic. The red circles indicate the location of a university, college or campus within the Arctic. The size of the circle corresponds to the number of educational institutions in a specific location. There is a particularly high concentration of education institutions around Anchorage (Alaska), as well as in Iceland, the Faroe Islands and Arctic Fennoscandia (see zoom-in maps). Yukon College is the main educational institution in Yukon (Canada), and has several campuses across the region. In the Russian Arctic regions, the largest centres with higher educational institutions are Murmansk, Naryan-Mar (Nenets), Nizhnevartovsk (Khanty-Mansi), Salekhard (Yamalo-Nenets), and Yakutsk (Sakha).

\subsection{Labour market}

Maps 6-4 to 6-7 show employment and unemployment conditions in the Arctic in 2016, based on OECD data. Map 64: Labour force participation rate depicts the active population as a share of total population in the Arctic region. The active population includes all persons (aged 15 and over) who have at least one current paid job or are searching for one. The Russian Arctic regions of Chukotka (83.6\%), Yamalo-Nenets (78.0\%) and Magadan (76.1\%) had the highest participation rates. The lowest participation rates were in Lappi (53.3\%) (Finland) and Nordland (59.9\%) (Norway).

The employment rate consists of the ratio between the employed population and the workingage population. Employed persons are those aged 15 or over who report that they worked in gainful employment for at least one hour in the previous week, or who have a job but were absent from work during the week in question. ${ }^{12}$ The highest employment rates were in the Faroe Islands, Svalbard, Yukon (71.5\%) (Canada), Chukotka (80.9\%), Yamalo-Nenets (75.2\%) and Magadan Oblast (73.7\%) (Russian Federation). The lowest employment rates were in Lappi (48.1\%) (Finland), Newfoundland and Labrador (52.4\%) and Nunavut

12 OECD (2018): https://data.oecd.org/emp/employmentrate.htm 


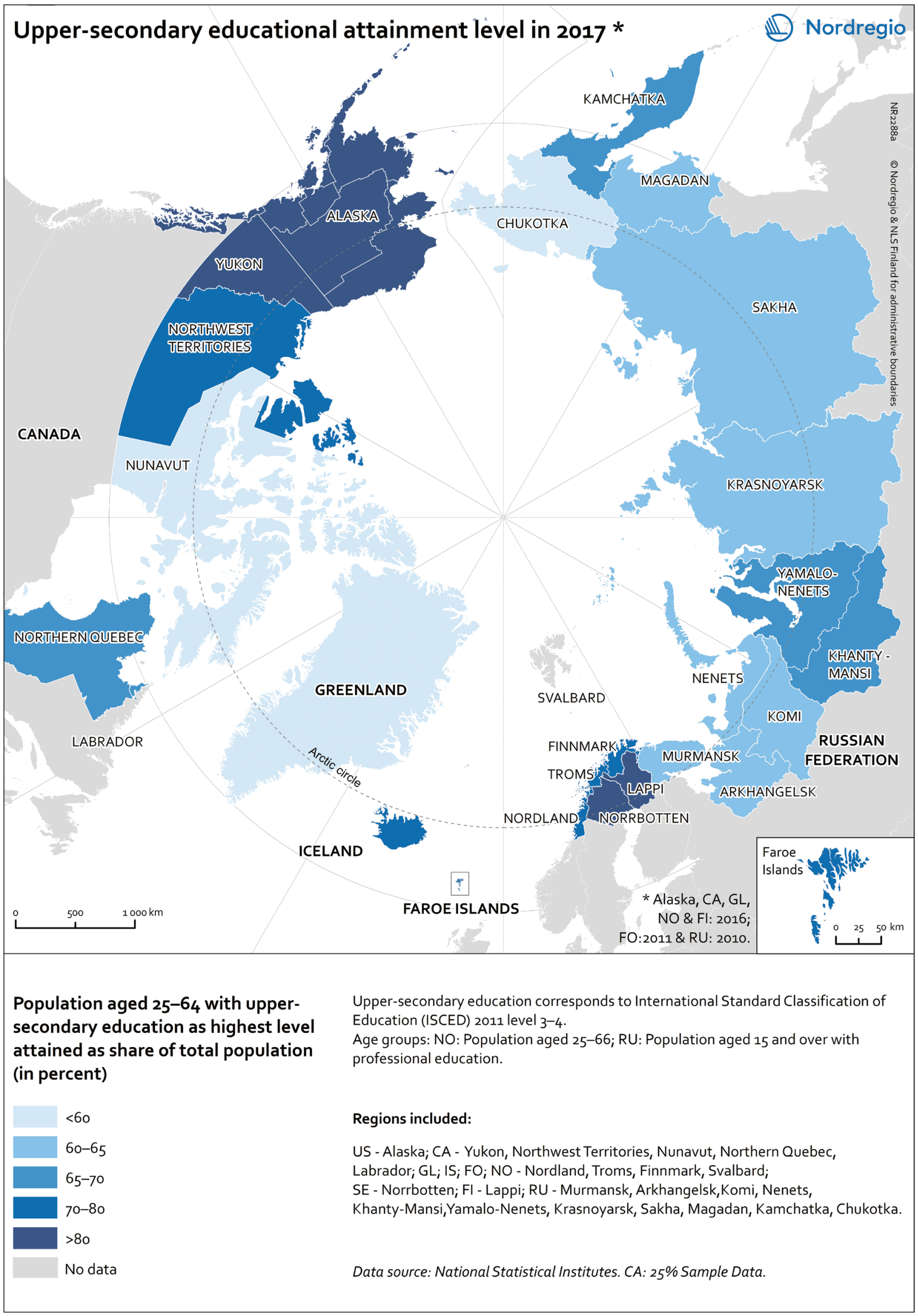

Map 6-1 Upper-secondary educational attainment level in the Arctic in 2017. 


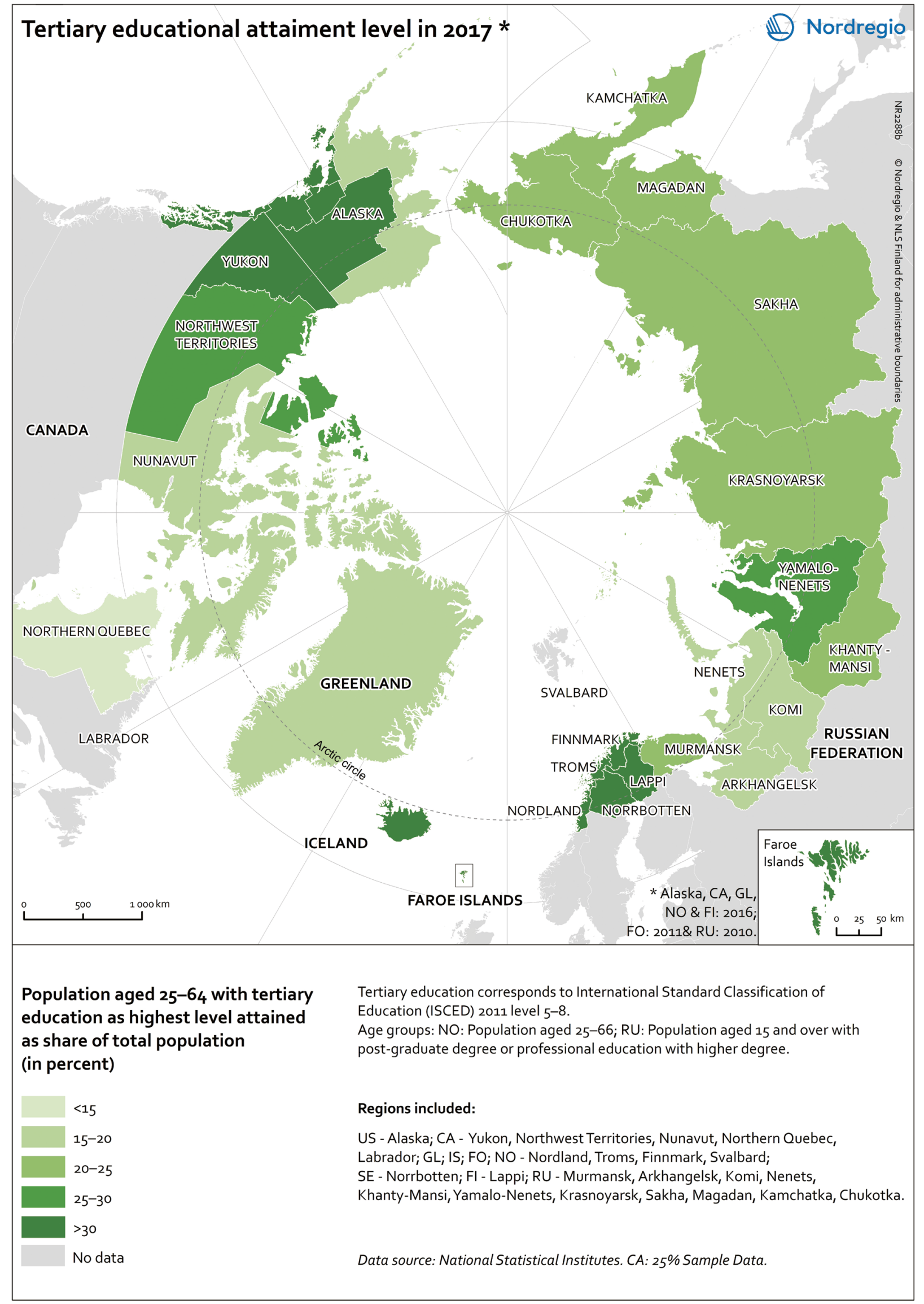

Map 6-2: Tertiary educational attainment level in the Arctic in 2017. 


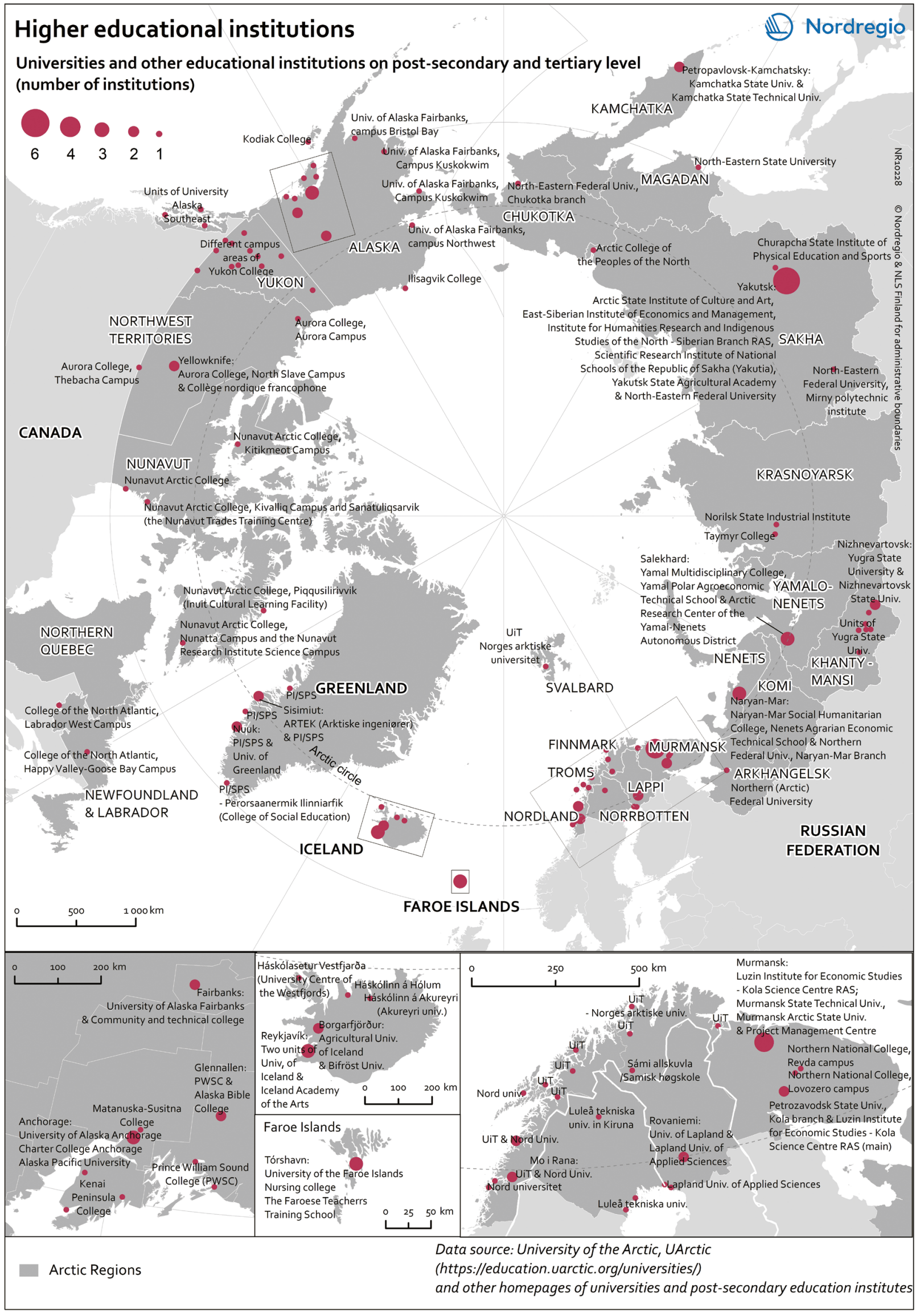

Map 6-3: Higher educational institutions in the Arctic. 
(53.0\%) (Canada). The employment rate in the Nordic Arctic regions was lower than the average of their respective countries, whereas in Alaska (USA) and the Russian Arctic, the employment rate was higher than the average.

Map 66: Part time employment incidence depicts the share of part-time employees compared to total employment in the Arctic regions in 2014. Part-time workers are persons (aged 15 and over) who work fewer than 30 hours per week. The highest incidence of part-time employment was seen in the three Arctic regions of Norway: Nordland (59.5\%), Troms (56.3\%) and Finnmark (56.0\%). The Russian Arctic regions of Yamalo-Nenets (0.9\%), Khanty-Mansi (2.5\%) and Chukotka (3.4\%) had the lowest part-time employment incidence. Greenland is not included in the OECD data for part-time employment. However, according to their national statistical institute, part-time and seasonal work is very common in fishing, agriculture and other industries in the primary sector.

The unemployment rate in the Arctic regions mostly follows the national averages. Map 67: Unemployment rate depicts unemployed persons as share of the labour force in the Arctic regions in 2016. Nunavut (14.0\%) and Newfoundland and Labrador (13.4\%) (Canada) had the highest unemployment rates. The unemployment rate was the lowest in Finnmark (2.6\%), Nordland (3.3\%), and Troms (3.3\%) (Norway), the Faroe Islands (3.3\%) and Iceland (3.0\%), as well as in three Russian Arctic regions: Magadan (3.1\%), Yamalo-Nenets (3.1\%), and Chukotka (3.2\%).

Figures 6-8 and 6-9 show the share of young unemployed persons (aged 15-24) in relation to the overall labour force. Figure 6-8 shows the youth unemployment rate in 2014 at the national level, while Figure 6-9 shows the youth unemployment rate in 2016 at the regional level (the years differ due to the availability of OECD data). At the national level, Sweden (22.9\%) had the highest youth unemployment rate, although this has decreased since 2014. It should be noted, however, that Sweden and Finland's national statistics classify full-time students looking for work as unemployed youth. ${ }^{13}$ The Faroe Islands had the lowest level of youth unemployment (2.9\%).

13 https://www.elmmagazine.eu/articles/a-nordicperspective-on-youth-unemployment/

\section{Employment in sectors and economic activities}

Maps 6-10 and 6-11 show the distribution of employment in public and private sectors in the Arctic at regional level in 2017. The average share of employment in the public sector was $32 \%$, and $68 \%$ in the private sector. Public-sector employment dominates in many regions of the Arctic, as states and regional authorities are involved in most regulation and planning activities. Recently, however, the emerging private sector has to some extent replaced the public authorities as the main service provider. Alaska (USA), Northern Quebec, Newfoundland and Labrador (Canada), the Nordic Arctic Region, Yamalo-Nenets and Khanty-Mansi (Russian Federation) are among the regions with the lowest share of employment in the public sector. Conversely, Nunavut (Canada), Murmansk, Arkhangelsk, Sakha, Kamchatka, Magadan and Chukotka (Russian Federation) had the highest share (over $50 \%$ ) of public-sector employment.

Maps 6-12, 6-13 and 6-14 provide further details in relation to economic activities in the Arctic in 2016, and depict employment in the primary, secondary and tertiary sectors, respectively. The primary sector includes economic activities such as agriculture, forestry, fishery, mining and quarrying. The average share of the primary sector in the Arctic was $14 \%$. The highest share of employees working in the primary sector was in the Russian Arctic regions - Nenets, Yamalo-Nenets, KhantyMansi and Chukotka. The lowest share was in the Yukon, Nunavut, Nunavik (Canada), Iceland, Troms and Nordland (Norway). The secondary sector includes economic activities such as manufacturing, construction, electricity, gas and water. The average share of the secondary sector was $20 \%$. The share of employment in the secondary sector was relatively high in both the Nordic Arctic regions and the Russian Arctic. Greenland and Nunavik (Canada) had the lowest proportion of employees working in the secondary sector. The tertiary sector corresponds to market and non-market services. The average share of the tertiary sector was $66 \%$. There was a relatively high share of employees in the tertiary sector in Alaska (USA) and in the Canadian Arctic, with the exception of Labrador. In the Russian Arctic, however, a low share of employees work in the service sector.

The employment structure differs in the Arctic depending on the specific branch of economic activity. Map 6-15 shows how the employment structure of the regions compares to the Arctic 
average. This is based on cluster analysis with the software Philcarto, ${ }^{14}$ which we used to calculate the share of employment in each economic branch at the regional level, as well as the Arctic average. We then compared the regional values with the Arctic average. This method therefore identifies regions with an overrepresentation of employment in each economic branch. Greenland is primarily dominated by agriculture, forestry and fishing, due to its strong fishery industry. In the Russian Arctic, Nenets had high employment in mining and quarrying (oil and gas), while Chukotka had high employment in electricity, gas and water supply. In Labrador (Canada), Svalbard (Norway), Yamalo-Nenets and Khanty-Mansi (Russian Federation), the most dominant branch was construction. Mining and quarrying activities were also overrepresented in Labrador (Canada), due to the extraction of minerals, and in Yamalo-Nenets and Khanty-Mansi in Russia, with the extraction of oil and gas. Manufacturing, including of food products, wood, plastic, mineral and metal products, and electrical and transport equipment, was more dominant in Iceland, Arkhangelsk and Krasnoyarsk (Russian Federation). The majority of the Canadian Arctic and the Nordic Arctic regions had a balanced industrial profile, with only minor overrepresentation of public administration. Elsewhere in the Arctic, particularly the large cities, there was a balanced industrial profile.

\subsection{Production}

Production is measured on the basis of GDP (Gross Domestic Product), GRP (Gross Regional Product), GVA (Gross Value Added), disposable household income and share of housing by private and public ownership.

GDP (Gross Domestic Product) and GRP (Gross Regional Product). GDP measures a country's overall economic output (in terms of purchasing power parity). GRP is a corresponding indicator measuring the overall economic output at regional level. While these measures are a simplification of the concept of regional economic performance, they are the most commonly used and harmonised stable measures for economic comparison. In this report, they are used in conjunction with labour market data and an overview of indicators from

14 http://philcarto.free.fr/ different economic sectors to provide a broad understanding of regional economic development.

Map 6-16 shows the GRP per capita in purchasing power parity (PPP) in the Arctic regions in 2016. Alaska (USA), the Canadian Arctic and the Nordic Arctic regions performed well in relation to the Arctic average. Alaska (USA), Northwest Territories (Canada) and Svalbard (Norway) performed best. In the Russian Arctic, there were large disparities between the regions. Nenets, Yamalo-Nenets, and Khanty-Mansi all performed well. Chukotka's GRP (in PPP) was also above the Arctic average. However, the remaining regions - especially Murmansk, Arkhangelsk and Kamchatka - were far below the Arctic average. This variation is largely due to the region's economic structure. In general, sub-regions engaged in raw material extraction tend to be characterised by higher GRPs and stronger economic development.

GVA (Gross Value Added) per main sector is the measure of the value of goods and services produced in a particular area, industry or sector. The GVA is calculated based on economic output valued at basic prices, minus intermediate consumption valued at purchaser's prices. The GVA is linked to the GDP, as both are measures of economic output. However, the GVA is sector-specific, while the GDP is the total sum of GVA across all sectors of economy (including taxes, excluding subsidies). Map 6-17 uses two indicators to present GVA at regional level in 2016: total GVA per capita in PPP, and GVA by branch of economic activity.

For Alaska (USA), all regions in the Canadian Arctic, as well as Yamalo-Nenets and KhantyMansi, the total GVA was above the Arctic average of $€ 30,000$. In Alaska (USA), Yukon, the Northwest Territories and Nunavut (Canada), public services and industry were the two largest branches. In Northern Quebec and Newfoundland and Labrador (Canada), industry was the dominant branch in terms of GVA. The situation was slightly different in the Nordic Arctic regions, with large shares of GVA in agriculture, forestry and fishing. Fishing was particularly dominant in Greenland and the Faroe Islands. In the Nordic Arctic regions (except Lappi, Finland), the total GVA from all branches was above the Arctic average.

Norrbotten (Sweden) and Lappi (Finland) had a high GVA in the industry branch. The largest shares of GVA in public services were in Arctic Norway and the Faroe Islands. In Svalbard, the most dominant branch was distributive trade, trade and 
communication, with no GVA from agriculture. The Russian Arctic showed contrasting pictures for each of the regions. Nenets, Yamalo-Nenets and Khanty-Mansi were among the Arctic regions with the highest total GVA. The other regions had a total GVA far below the Arctic average. Economic activities related to industry dominated most of these regions, with the exception of Kamchatka. Natural resources are the mainstay and backbone of the economy in the Russian Arctic. Compared to their countries as a whole, the Arctic regions had relatively low shares of financial, real estate, scientific and technical activities, and administrative and support services, but higher shares of public services, arts and other services.

Disposable household income: Gross Disposable Household Income (GDHI) is the amount of money that all of the individuals in households have available to spend or save once they have paid direct and indirect taxes and received any direct benefits. GDHI therefore reflects households' 'material welfare'. Figure 6-18 depicts the disposable household income per capita (USD per head, constant prices, constant PPP, base year 2010) in 2015 in the Arctic regions. The figure is based on OECD data, which defines the indicator as the sum of household final consumption expenditure and savings, minus the change in households' net equity in pension funds. The indicator also reflects the sum of wages and salaries, mixed income, net property income, net current transfers and social benefits other than social transfers in kind. ${ }^{15}$ Alaska (USA) had the highest disposable household income (USD 47,418 in 2015), while the Russian Federation had the lowest (USD 16,657 in 2013). Due to data availability, Figure 6-18 does not show information at the regional level in the Russian Federation. However, according to the Russian Federal State Statistic Service, households' available monthly resources in the Russian Arctic zone ${ }^{16}$ (RUB 32,581.5, approximately USD 493) were higher than the Russian national average (RUB 24,209.8, approximately USD 366) in 2016. ${ }^{17}$

Housing in the Arctic: Favourable rental conditions are often correlated with employment. Map 619 shows the housing situation in the Arctic regions in 2016. The pie charts represent the share of owned and rented dwellings. Nunavut (Canada), Greenland, Svalbard (Norway) and Chukotka (Russian Federation) were characterised by a clear dominance of renter-occupied dwellings. Regions in which owner-occupied dwellings are dominant include Krasnoyarsk, Khanty-Mansi and Sakha (Russian Federation), where more than $85 \%$ of apartments were privately owned. Permafrost thaw is likely to destabilise housing infrastructure across the Arctic. The financial impact will differ depending on whether the residences are in public or private ownership.

\footnotetext{
15 OECD (2018): https://data.oecd.org/hha/householddisposable-income.htm

16 Rosstat definition for Russian Arctic Regions

17 Rosstat (2018): http://www.gks.ru/free_doc/new_site/

region_stat/calendar1-2017.htm
} 


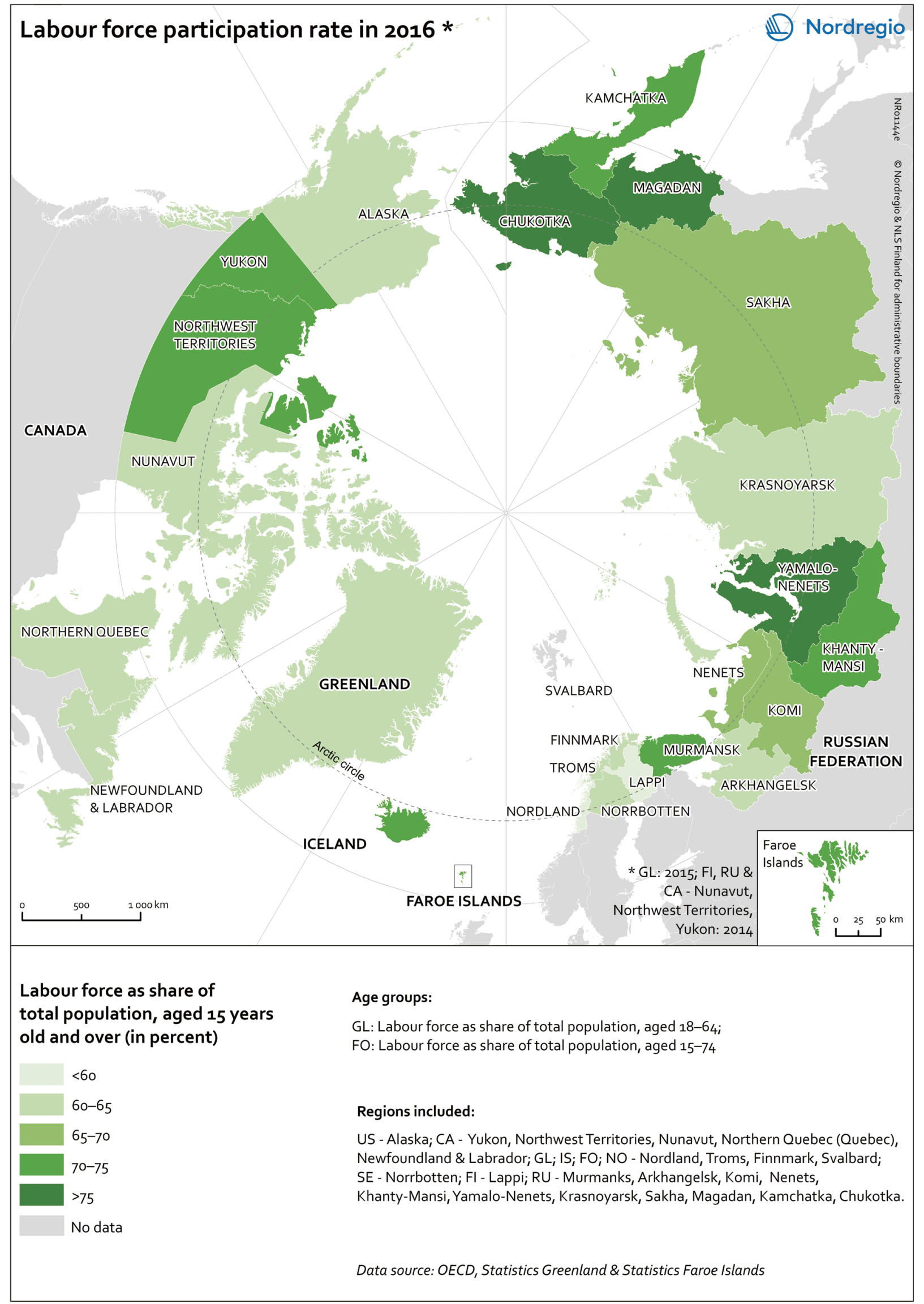

Map 6-4: Labour force participation rate in the Arctic in 2016. 


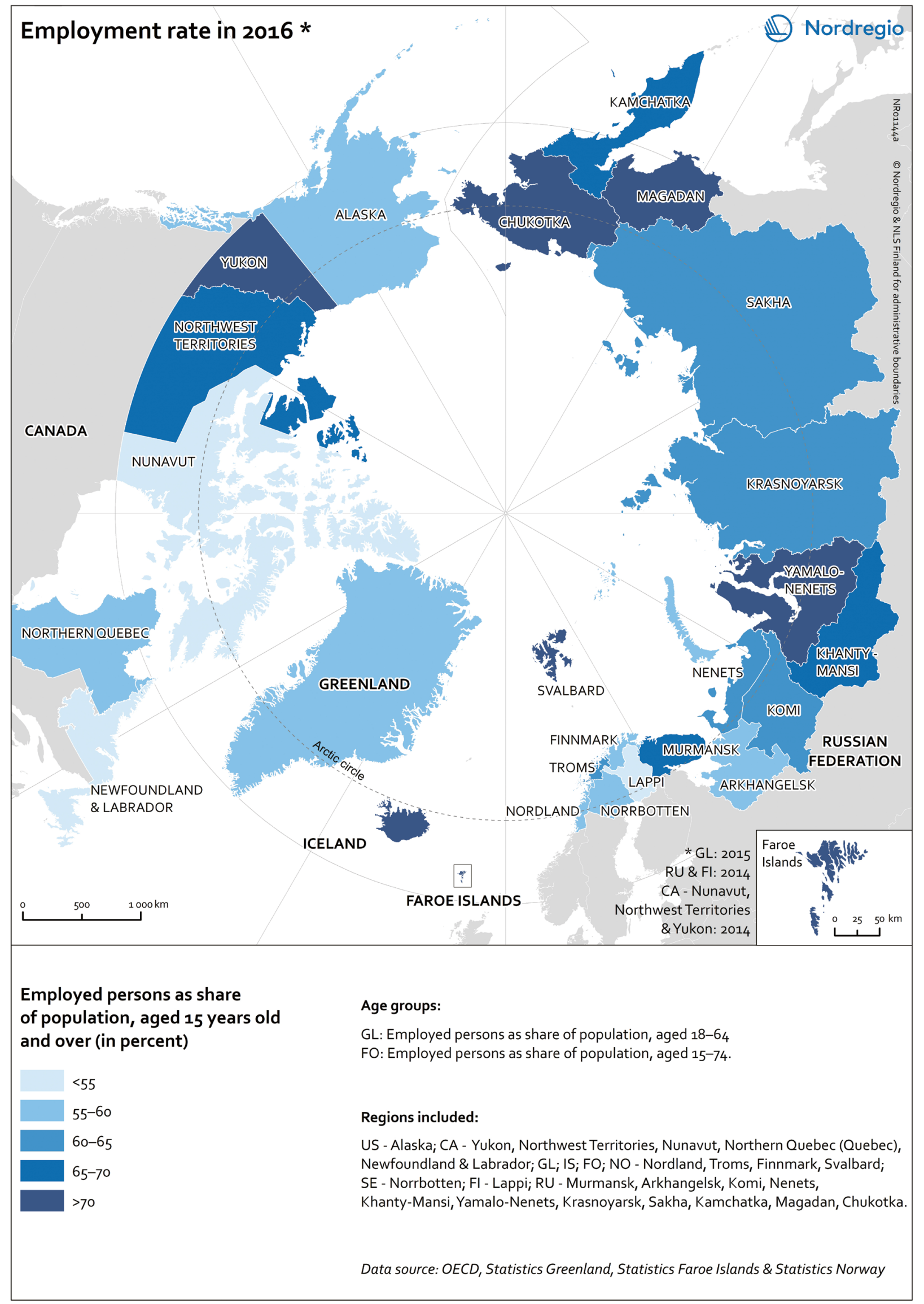

Map 6-5: Employment rate in the Arctic in 2016. 


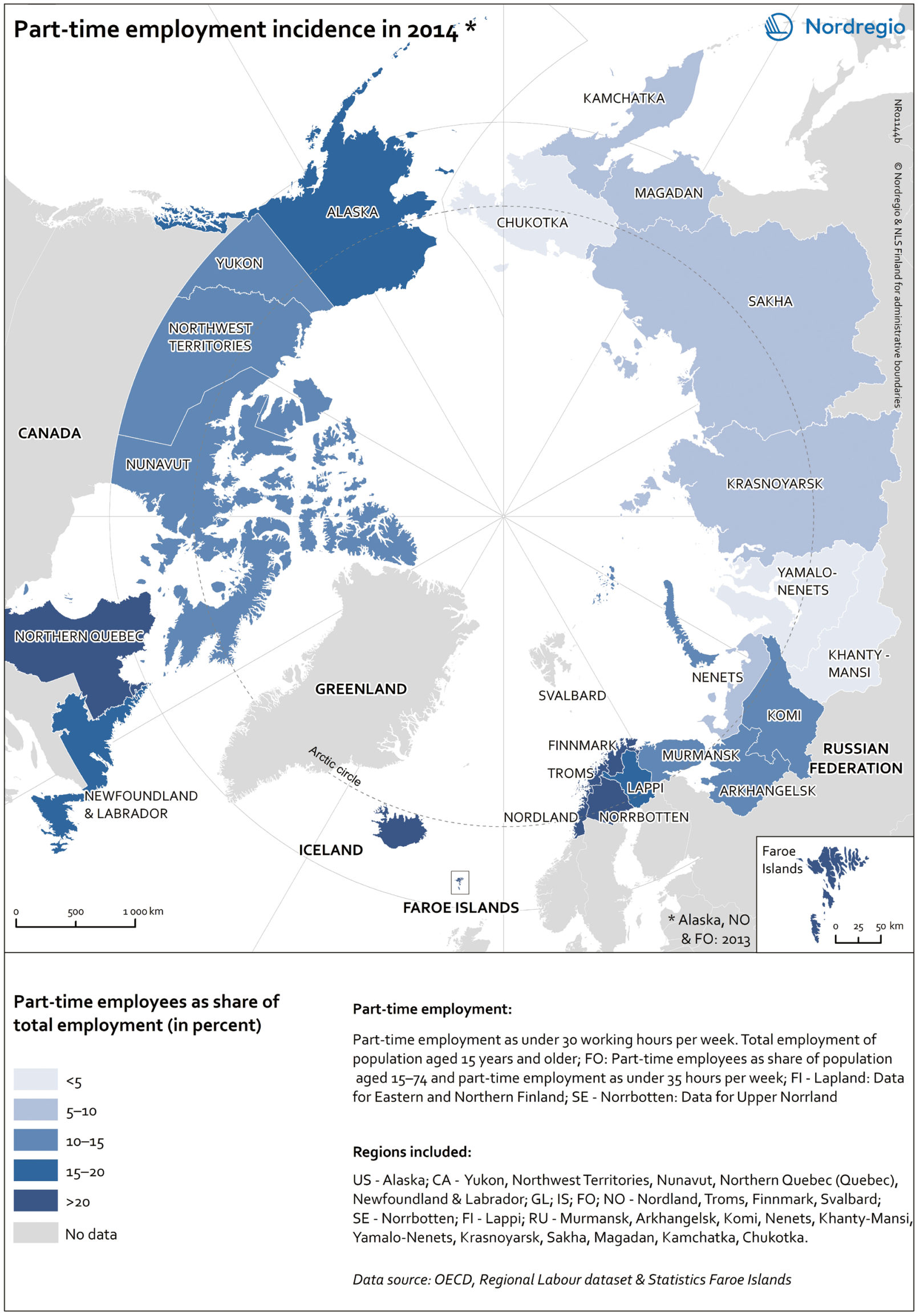

Map 6-6: Part-time employment incidence in the Arctic in 2014. 


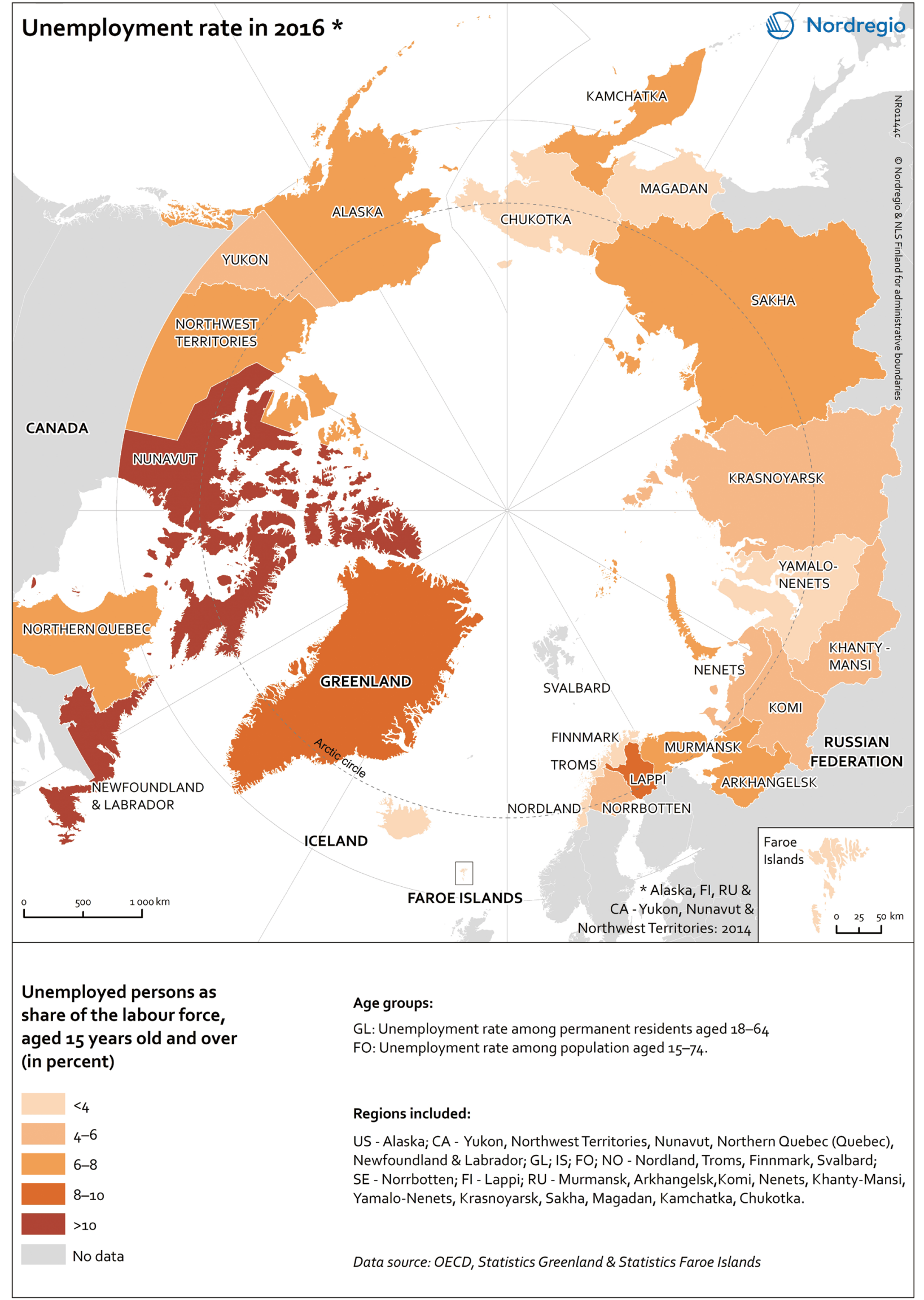

Map 6-7: Unemployment rate in the Arctic in 2016. 
Arctic youth unemployment rate 2014 (in percent)

Data on national level

FO: 2017, Statistic Faroe Islands
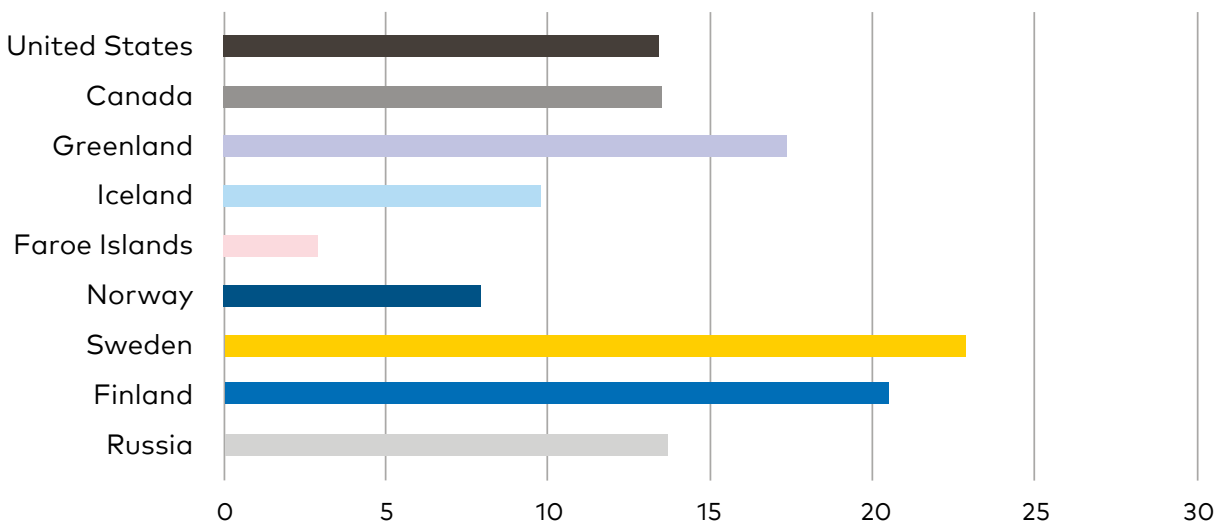

Figure 6-8: Arctic youth unemployment rate in 2014, national level.

\section{Arctic youth unemployment rate 2016 (in percent)}

Data on regional level

RU: 2015; Alaska: 2014

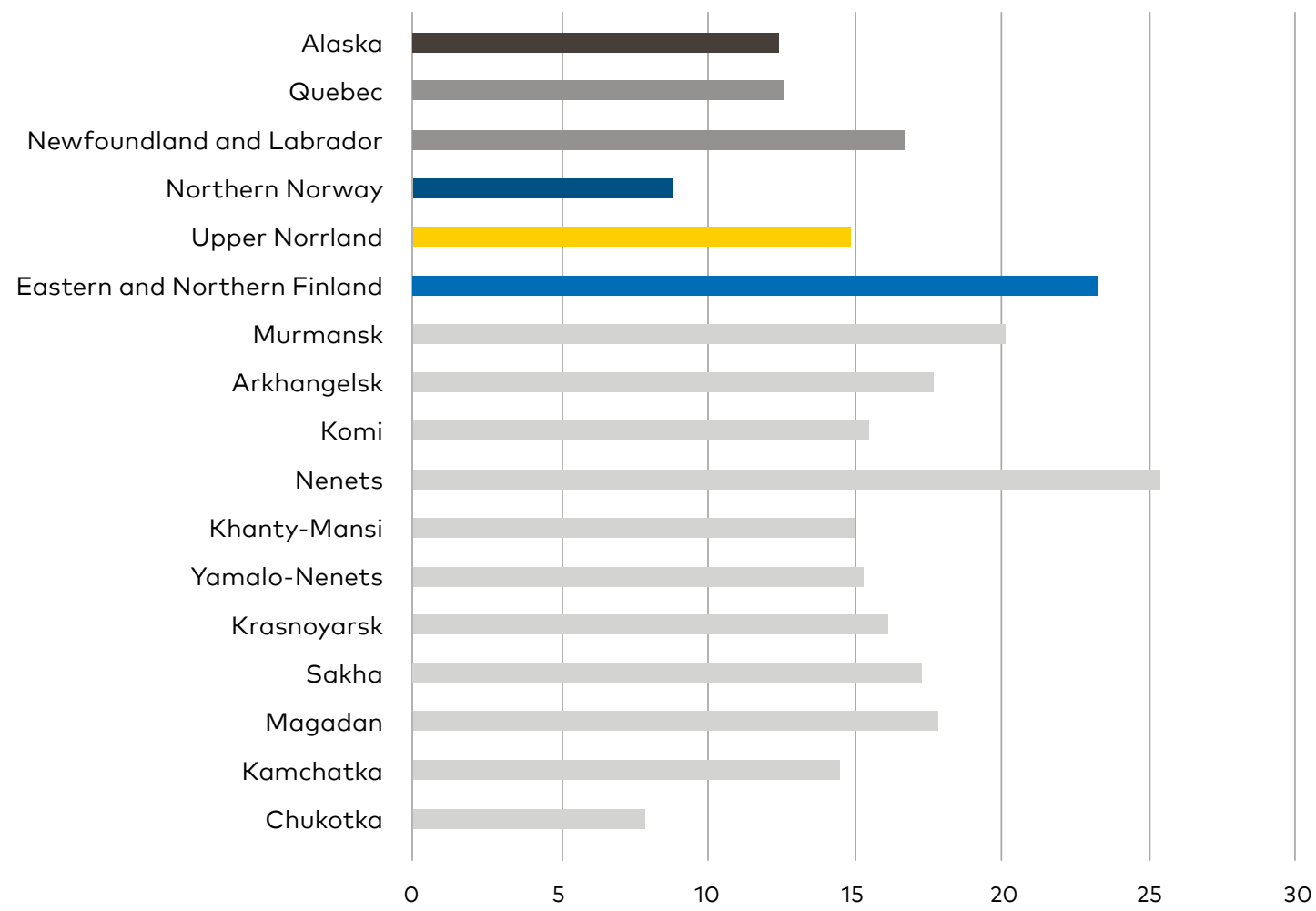

Figure 6-9: Arctic youth unemployment rate in 2016, regional level. 


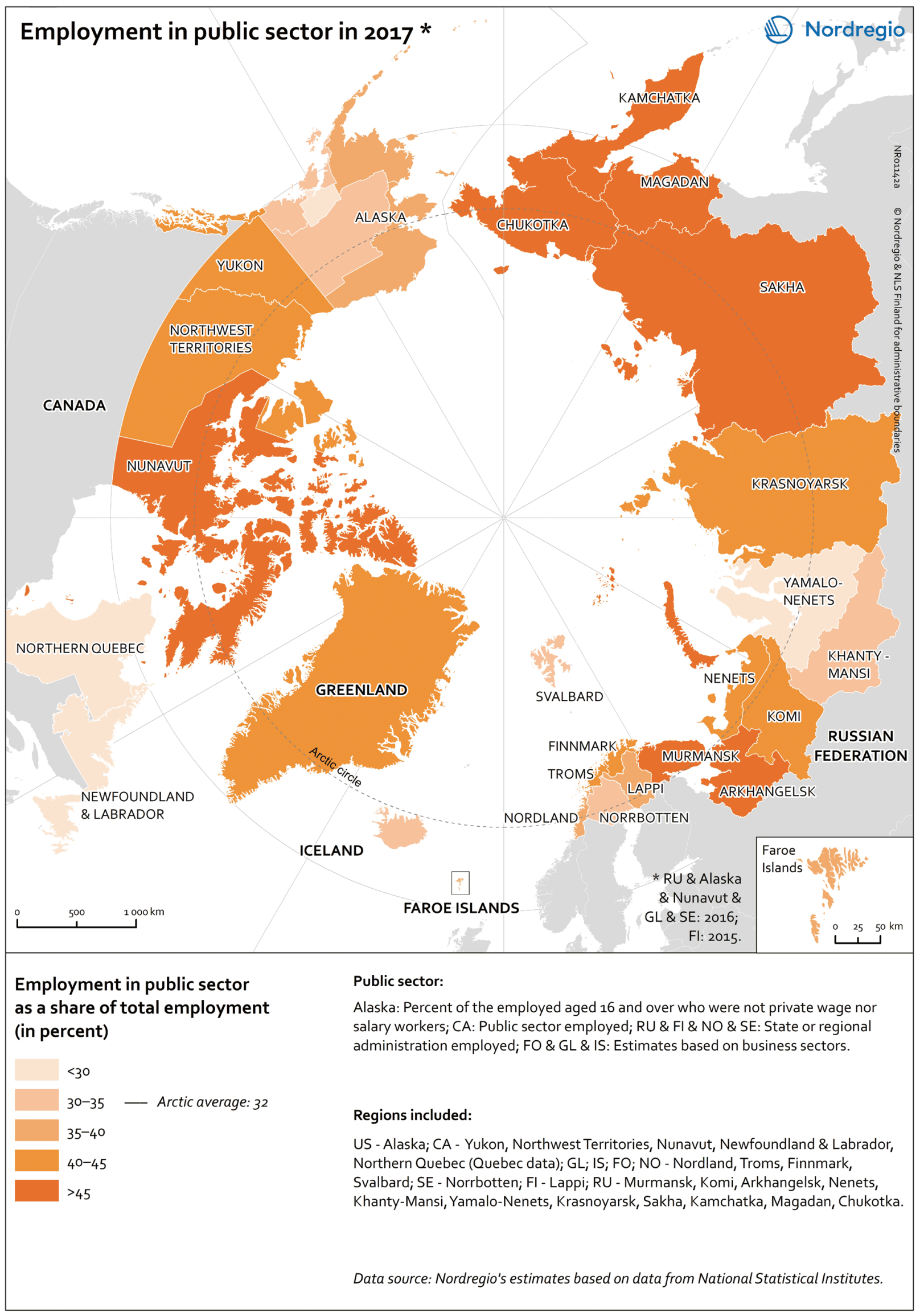

Map 6-10: Employment in public sector in the Arctic in 2017. 


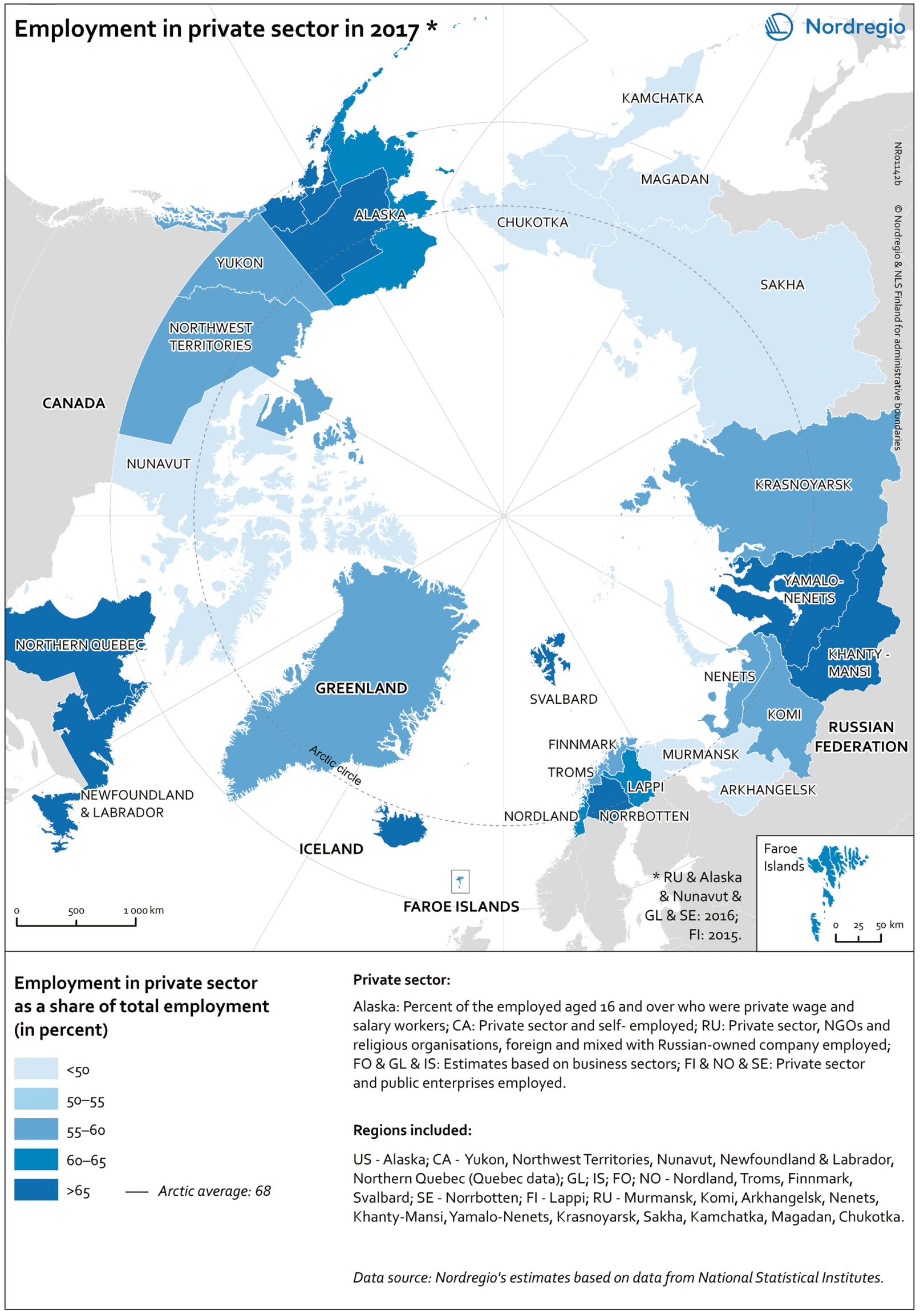

Map 6-11: Employment in private sector in the Arctic in 2017. 


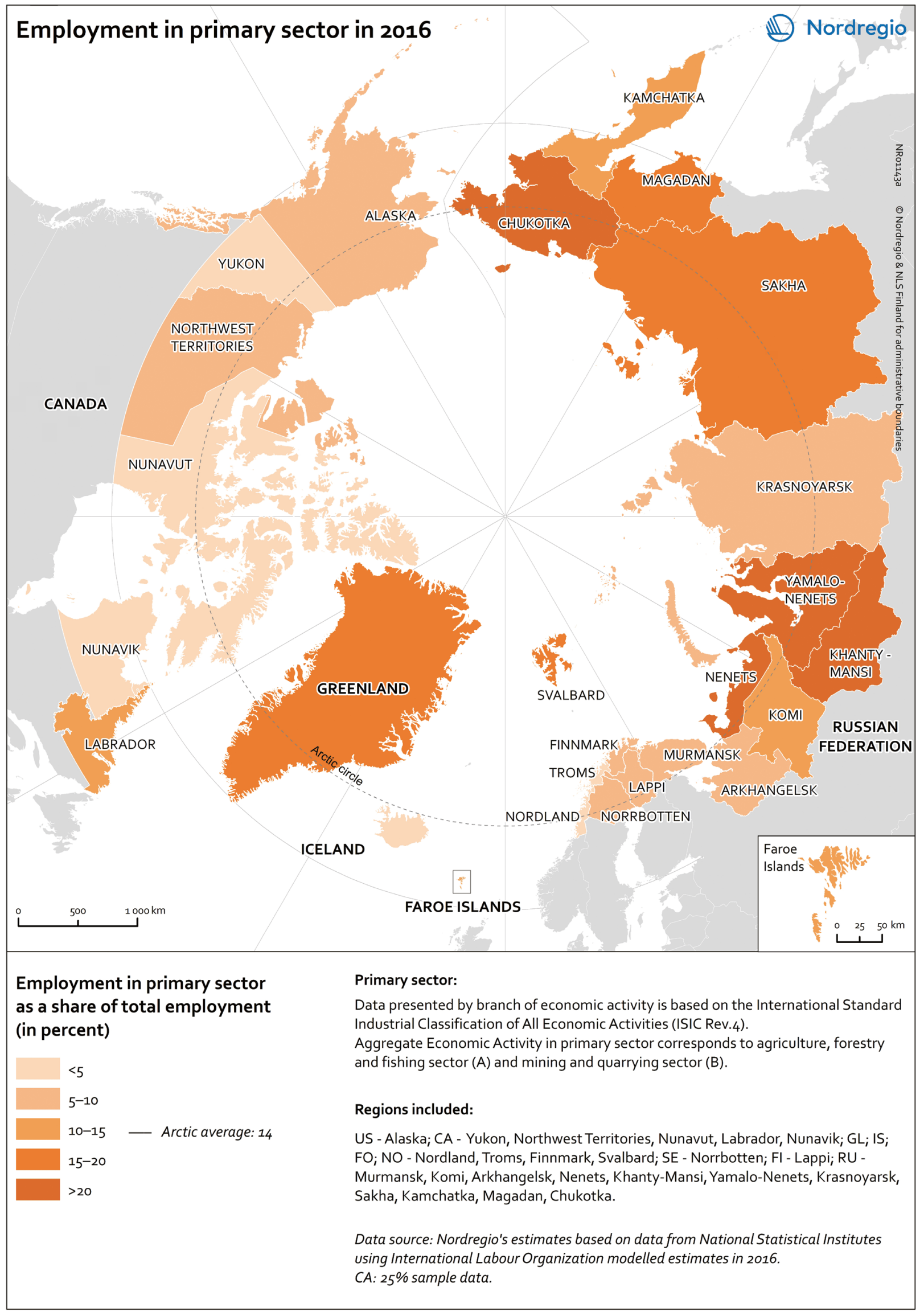

Map 6-12: Employment in primary sector in the Arctic in 2016. 


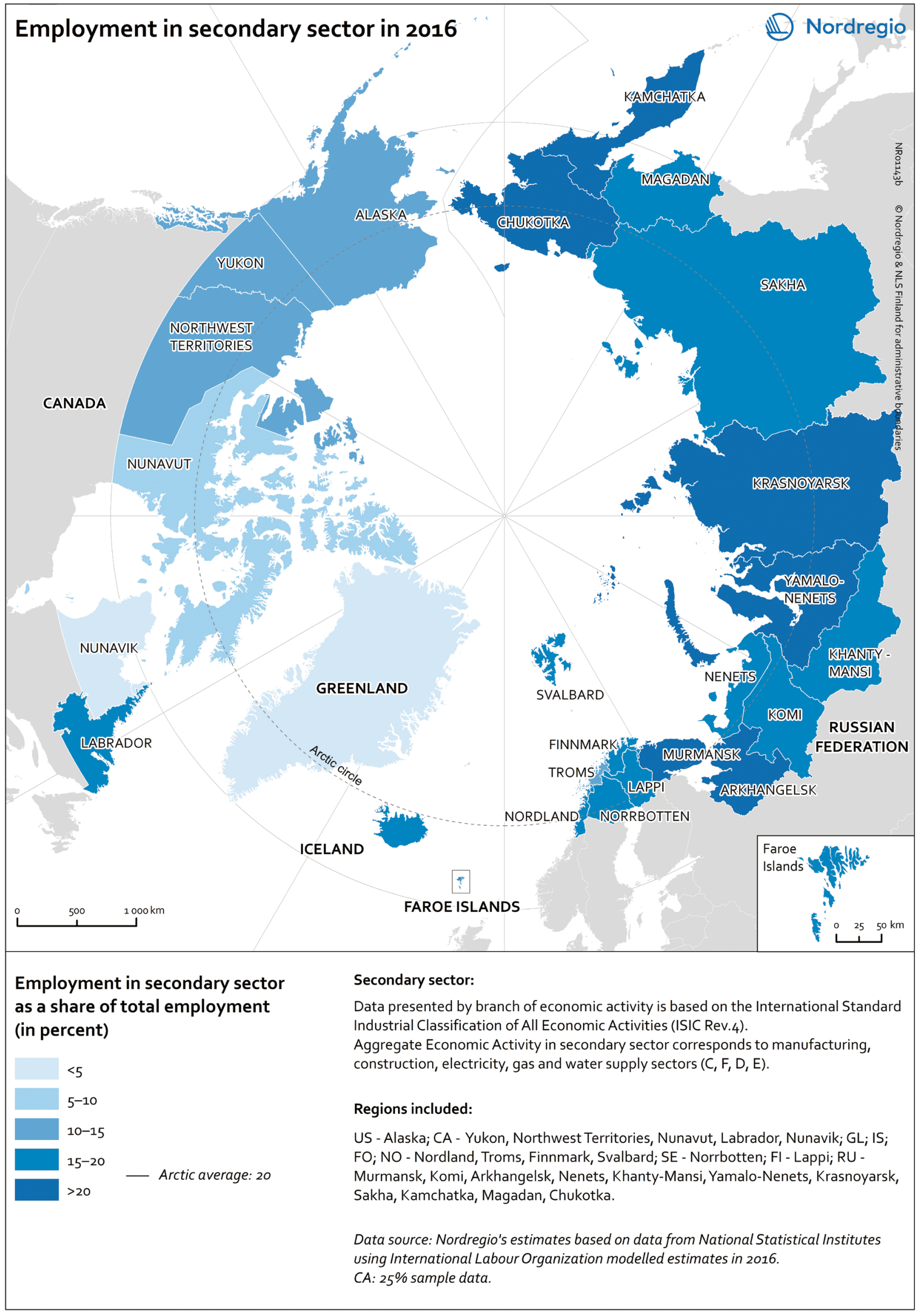

Map 6-13: Employment in secondary sector in the Arctic in 2016. 


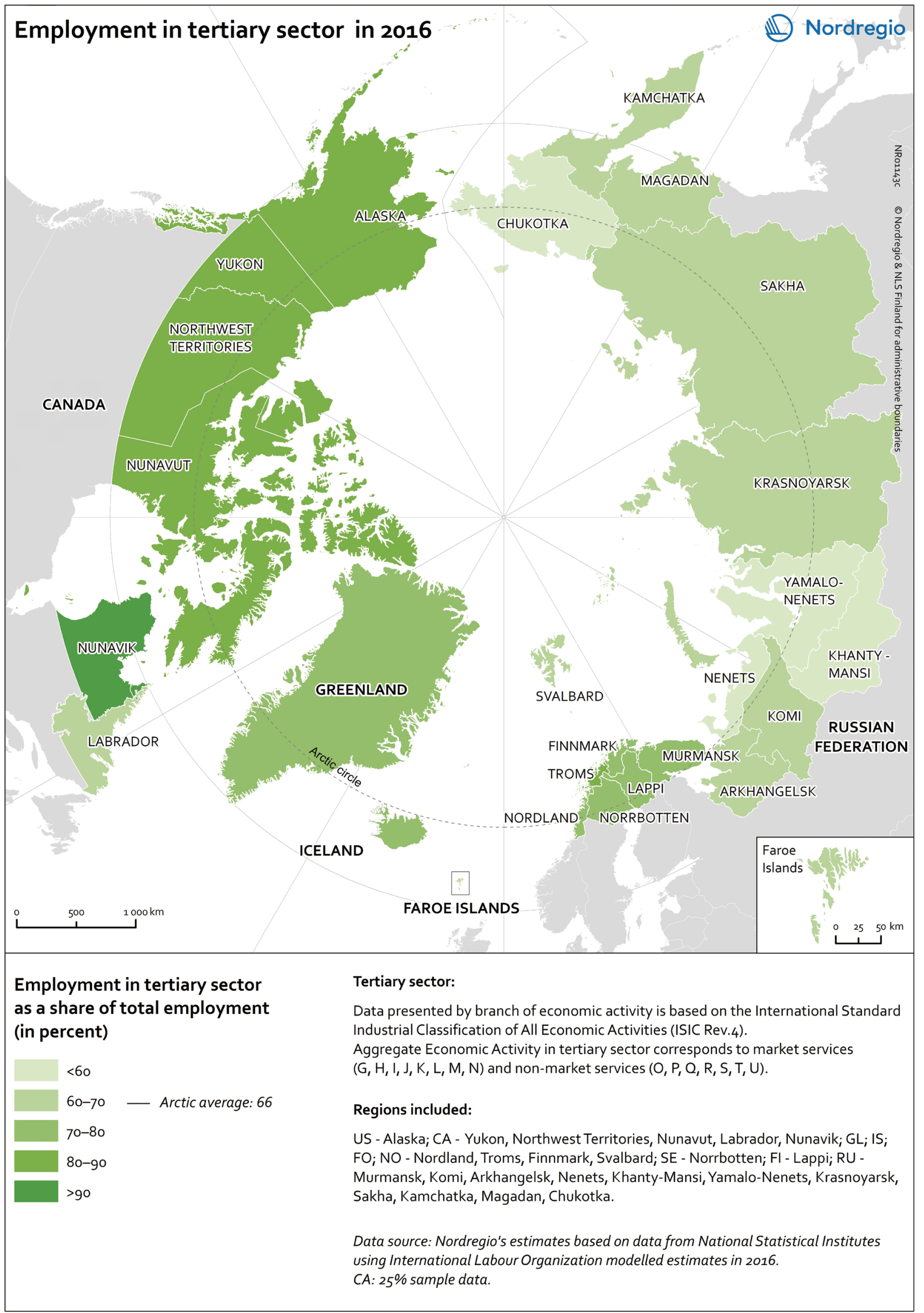

Map 6-14: Employment in tertiary sector in the Arctic in 2016. 


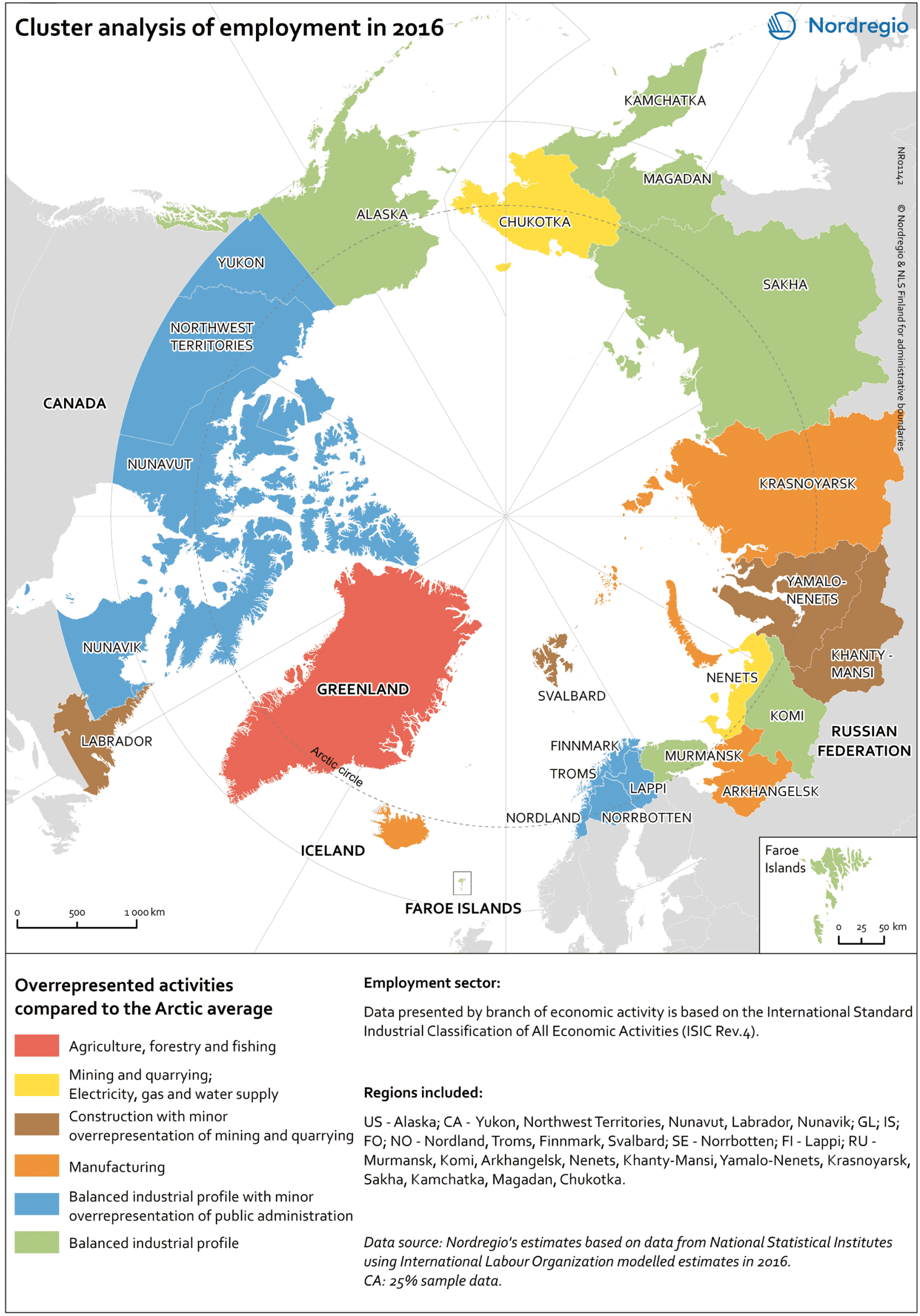

Map 6-15: Cluster analysis of employment in the Arctic in 2016. 


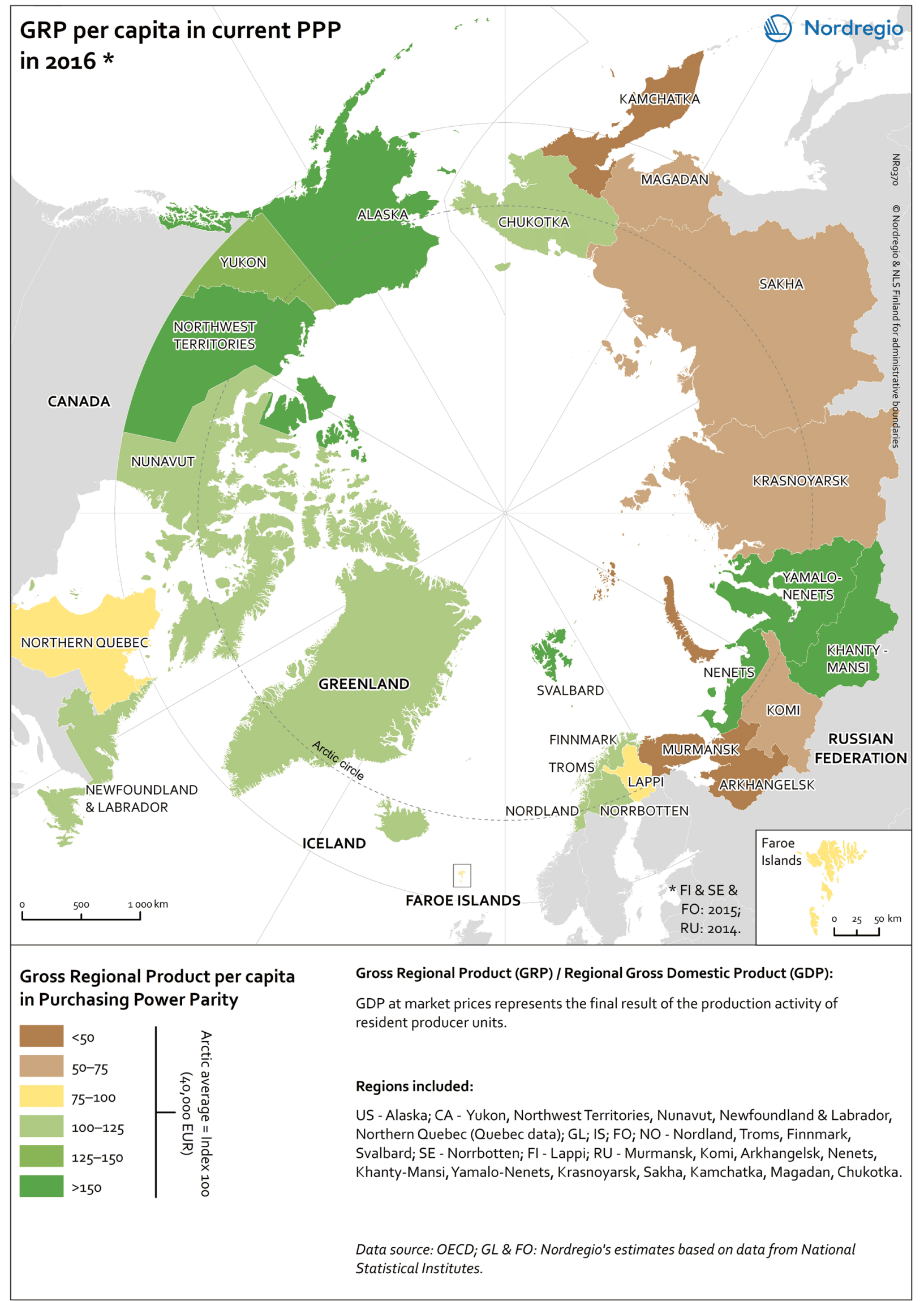

Map 6-16: Gross Regional Product per capita in current PPP in the Arctic in 2016. 


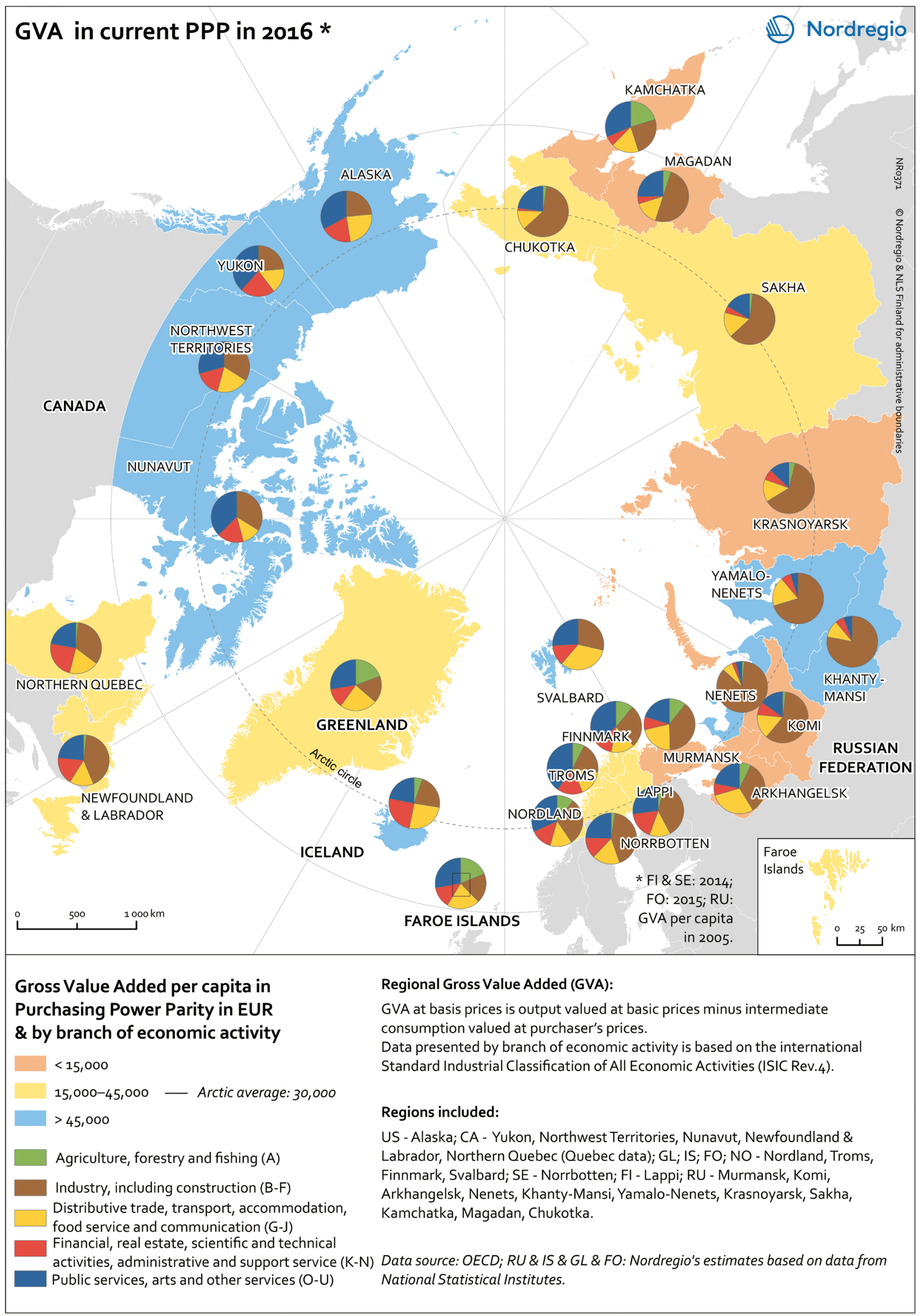

Map 6-17: Gross Value Added in current PPP in the Arctic in 2016. 


\section{Gross Disposable Household Income per capita $2015^{*} x$}

USD/per head, constant prices, constant PPP, base year 2010

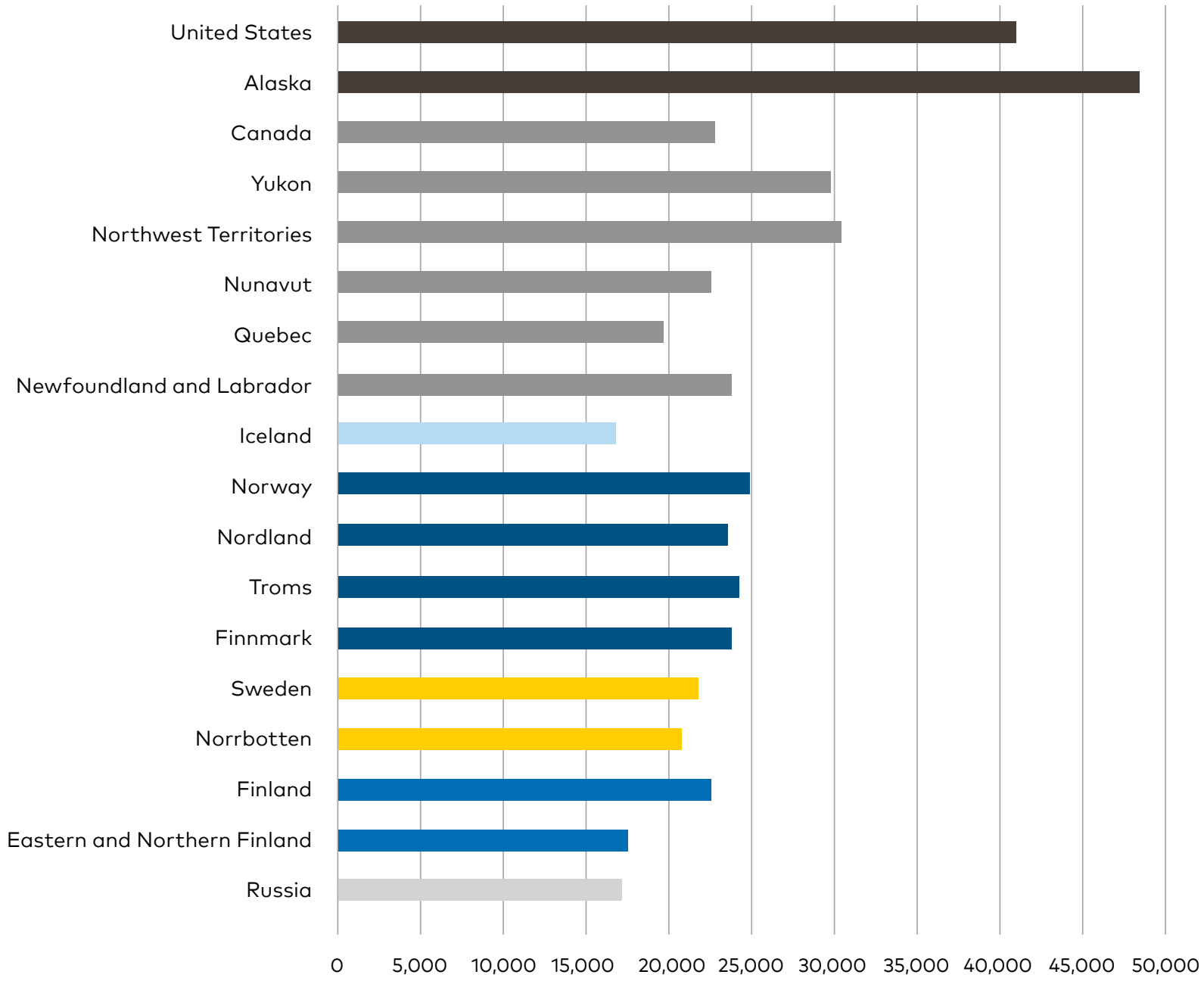

Figure 6-18: Gross disposable household income per capita in 2015. 


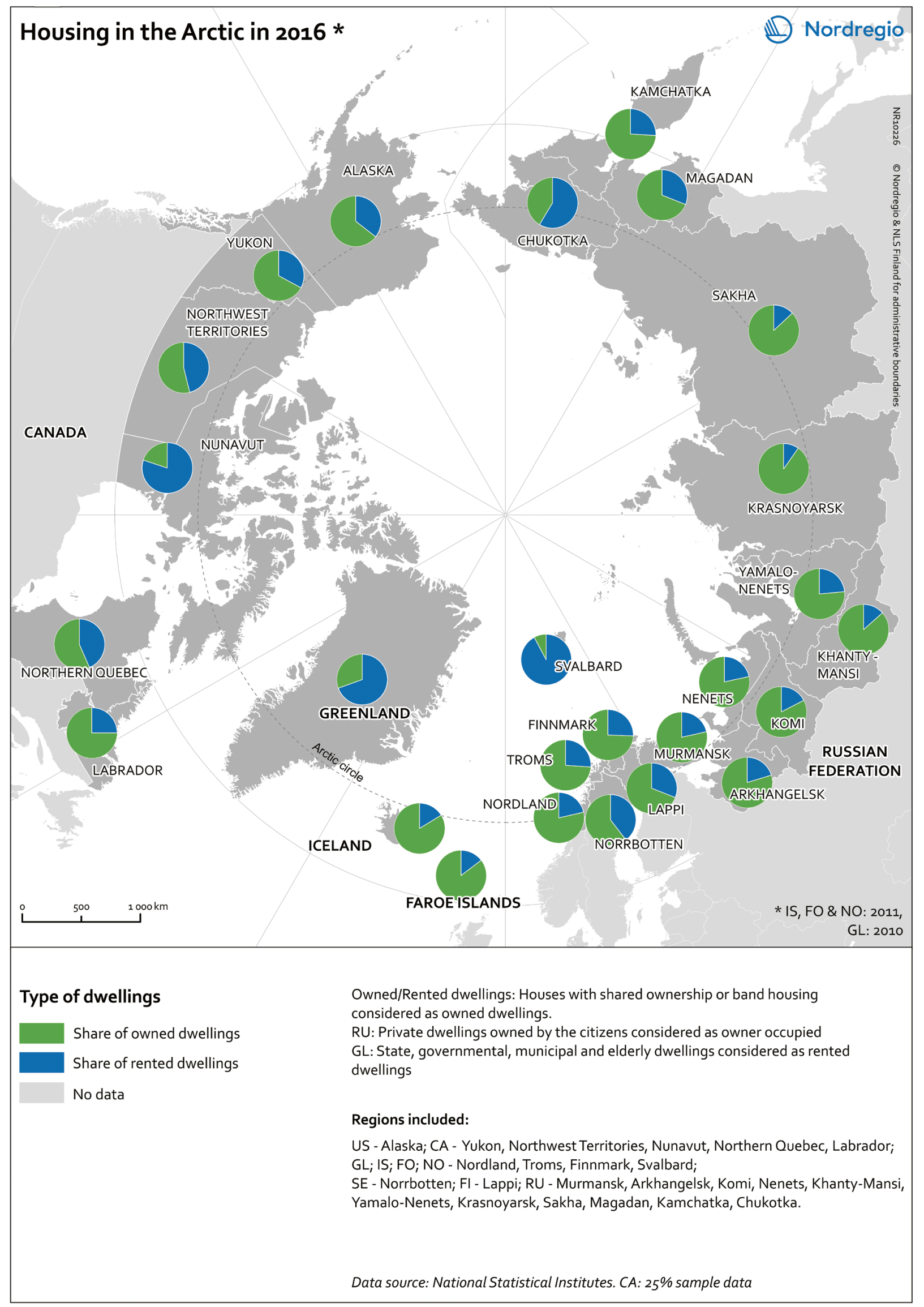

Map 6-19: Housing by type of dwellings in the Arctic in 2016. 


\section{Accessibility and infrastructure}

This section focuses on land-, air- and sea-based transportation networks, i.e. roads, railways, airports and ports in the Arctic regions. The purpose is to provide an overview of accessibility and infrastructure. The accessibility of many Arctic settlements is dependent on existing land, sea and aviation infrastructure. Permafrost thaw presents several challenges in terms of engineering, and may have a detrimental impact on many of these modes of transport. For many urban settlements, large infrastructural damage caused by permafrost thaw is a ever-present economic risk that planners must take into account. Permafrost thaw can have a particularly serious impact on rural and coastal settlements due to their small population size and limited (most often, single) means of commuting.

\subsection{Accessibility}

Map 7-1 illustrates the road network in the Arctic, and therefore the accessibility of Arctic settlements by road. The distribution of permafrost appears as a background layer that indicates the underlying physical conditions. The road infrastructure is considerably less dense on continuous permafrost-covered land. Some road connections in the Arctic are only open for transport during winter, but these are not distinguished on the map. Many settlements across vast areas of Greenland, Nunavut, Nunavik, and Labrador (Canada) are not connected to the road network. Travel by road therefore remains a challenge for inhabitants of these regions. The road infrastructure is generally better in Alaska (USA), the Northwest Territories and Yukon (Canada), where most of the settlements are accessible via road. The road networks in the Nordic Arctic regions - except Greenland are considerably denser than in other parts of the Arctic, and most of the settlements are connected to the road network. In Greenland, all transportation between cities takes place via aircraft, helicopter or boat. In the Russian Arctic, the road network is accessible for the inhabitants of most settlements, except in the Krasnoyarsk region, where there are a few road segments between settlements. Rail is not common in the Arctic region, with only a few connections between settlements in the Nordic Arctic and East Russia, and a handful of railways in the Russian Arctic, Alaska (USA) and Canada.

\subsection{Maritime transport and ports}

The main and secondary zones for maritime traffic are based on data for 2017 gathered via Marine Traffic's Automatic Identification System (AIS), ${ }_{18}^{18}$ which tracks vessels and plots their routes. The main transport areas are in Northern Europe from Iceland to the Kara Sea through the Norwegian coast - and along the coast of Alaska (USA).

Cargo ships, as well as government vessels, including icebreakers, account for the largest share of maritime traffic in the Arctic. However, private yachts and shipping activity related to tourism are on the rise.

The main transport corridors in the Arctic, the Northern Sea Route in the Russian Federation, the Northwest Passage in Canada and the Arctic Bridge from Canada to Europe have all experienced significant growth in maritime traffic in recent years. The Northern Sea Route - the shortest route between Europe and the Asia-Pacific region - is competing with traditional trade lines. Between 2016 and 2017, the total cargo volume on the Northern Sea Route increased by nearly $40 \% .{ }^{19}$ In the Canadian Arctic, the volume of traffic almost tripled between 1990 and 2015. ${ }^{20}$

With regard to increasing maritime traffic in the Arctic, there is a balance to be struck between economic interests and challenging physical conditions. Although the sea ice coverage is decreasing, the Arctic region is still a challenging environment.

\footnotetext{
18 https://www.marinetraffic.com/en/ais/home/centerx:-12.0/centery:25.0/zoom:4

19 https://www.highnorthnews.com/en/shipping-trafficnorthern-sea-route-grows-40-percent

20 https://www.highnorthnews.com/en/shipping-traffic-canadian-arctic-nearly-triples
} 


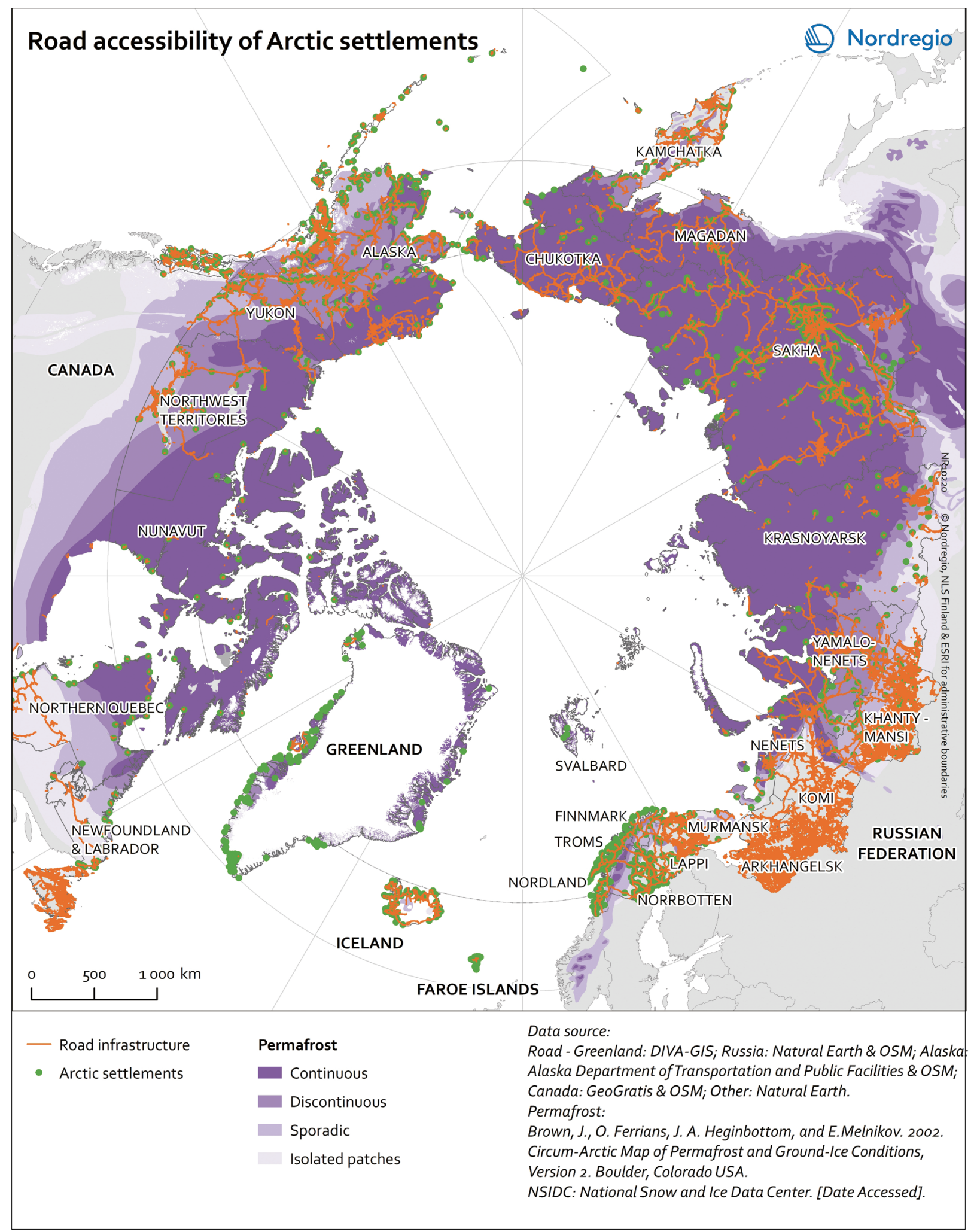

Map 7-1: Road accessibility in the Arctic. 


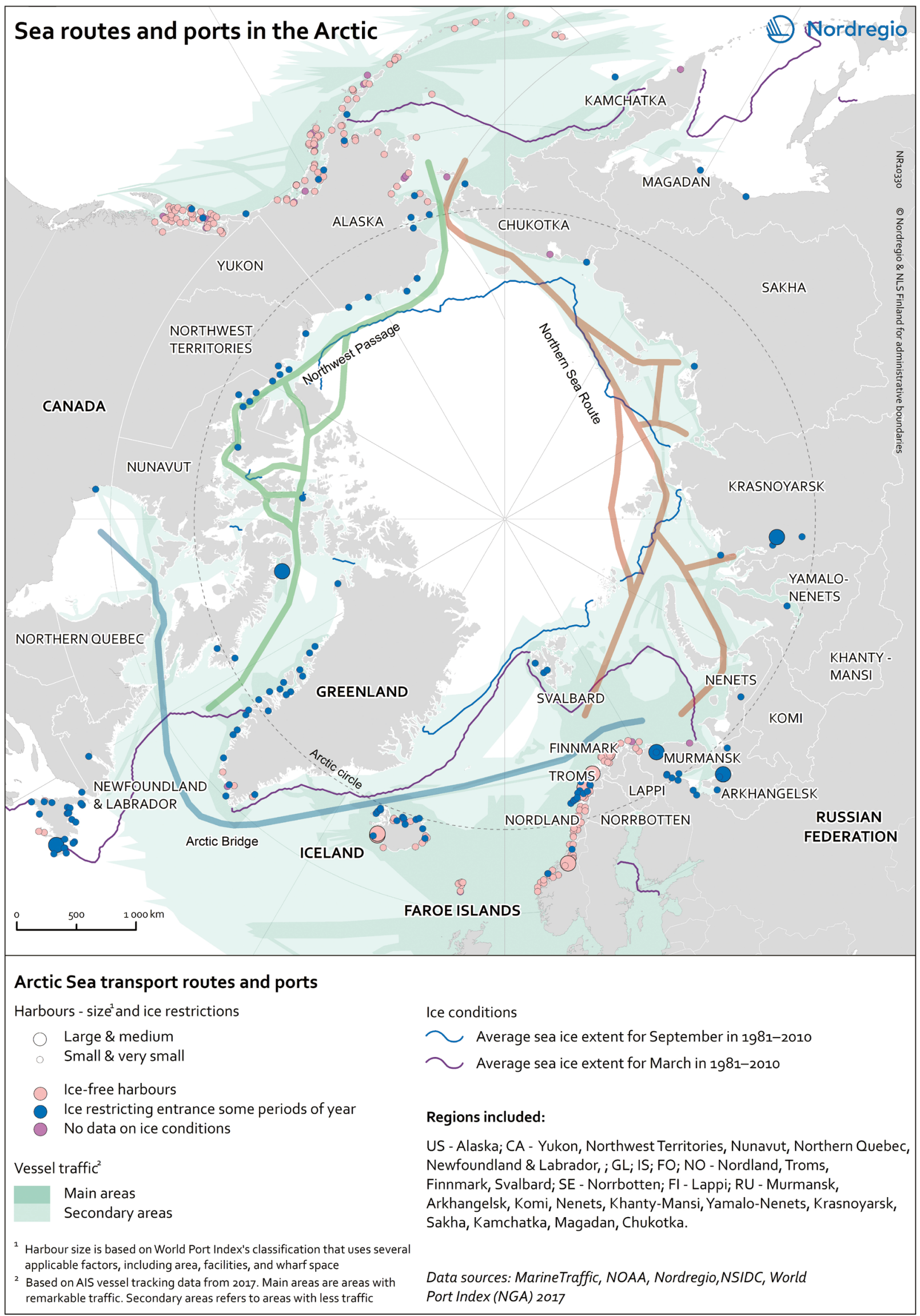

Map 7-2: Sea routes and ports in the Arctic. 
During winter, ice floes are unpredictable, and the conditions are subject to extreme seasonal variation. Traversing multiyear ice - which can be more than three metres thick - is challenging even for icebreakers, which are better equipped to handle first-year ice (less than one metre thick). Icebreaker escorts in winter are not only costly, but also limit the maximum width of the escorted vessel. Different challenges apply during open water season. For example, severe storms or heavy fog can obscure visibility and thus decrease transit speed. The lack of infrastructure in the region further complicates matters.

Map 7-2: Sea routes and ports in the Arctic plots the approx. 350 ports on the coasts of the Arctic Ocean, based on data from the World Port Index's database, which is published by the US National Geospatial-Intelligence Agency. ${ }^{21}$ The World Port Index describes the location, physical characteristics, facilities and services of major ports and terminals around the world. This map categorises the ports according to size and ice conditions. The size classification is based on several factors, including area, facilities and wharf space. By this definition, Murmansk is the only large port in the Arctic, while there are ten medium-sized ports. Almost 200 of the Arctic ports are ice-free all year round.

\subsection{Airports in the Arctic}

Long distances, combined with a lack of road and rail connections, and seasonal variations in maritime transport, make airports an essential part of accessibility in the Arctic. There are only a few large airports in the Arctic with regular air connections to national capitals or other main cities to the south or in other countries. However, there are many small airports.

The approximately 1,300 airports and heliports of the Arctic are shown on Map: 7-3: Airports in the Arctic. The main airport infrastructure comprises seven large and 260 medium-sized airports with regular passenger traffic. The small airports fall into two categories - those with an IATA code and those without. There are 265 small airports with an IATA code, most of which have regular air traffic. There are 500 small airports without an IATA code, which have some scheduled traffic, but generally only function as part-time aviation and

21 hhttps://msi.nga.mil/MSISiteContent/StaticFiles/NAV_ PUBS/WPI/Pub150bk.pdf landing sites for a few aircrafts. In addition, there are approx. 60 airports - mostly in the Russian Federation - that are not classified due to a lack of data regarding their size.

Greenland is heavily dependent on heliports. Many Greenlandic settlements are located along the shore, in small islands, by fjords or adjacent to mountains - sites where building an airport would be impossible or very expensive due to challenging physical conditions. All of the settlements therefore have either an airport or a heliport, depending on the size of the settlement and the physical conditions. In other Nordic Arctic regions, airports are located in the main settlements or on isolated islands. Almost all of the remaining settlements have road connections to an airport or a heliport. In the Canadian Arctic and Alaska (USA), almost all settlements have an airport. In the Russian Arctic, there are fewer airports. However, the map only indicates civil airports, while many airports and landing sites in the Russian Arctic are located in military areas.

\subsection{Infrastructure}

Households with broadband access: Map 7-4 shows the percentage of households with broadband access at the regional level in the Arctic in 2015. Dark purple shading indicates regions with a high share of households with broadband access, while light purple indicates regions with a low share. Grey shading indicates regions for which no data is available. Although the map shows that household access to broadband is generally rather good in the Arctic, there were still large disparities among the regions in the Russian Arctic. The lowest shares of households with broadband access were in Magadan (31.0\%), Chukotka (50.5\%), Sakha (55.0\%) and Nenets (56.0\%) (Russian Federation). Canada, Iceland and Norway had the highest share of households with broadband access (more than 90\%).

Generation of electricity by source: Figure 7-5 depicts generation of electricity by source in the Arctic countries in 2015. The figure is based on the data from US Energy Information Administration. The size of the circle corresponds to the volume of total electricity generated. Each circle indicates the source of electricity as a share of total production. Fossil fuels were still the largest source of electricity production, especially in the United States (67\%) and the Russian Federation (65\%), which were the biggest electricity producers in the 


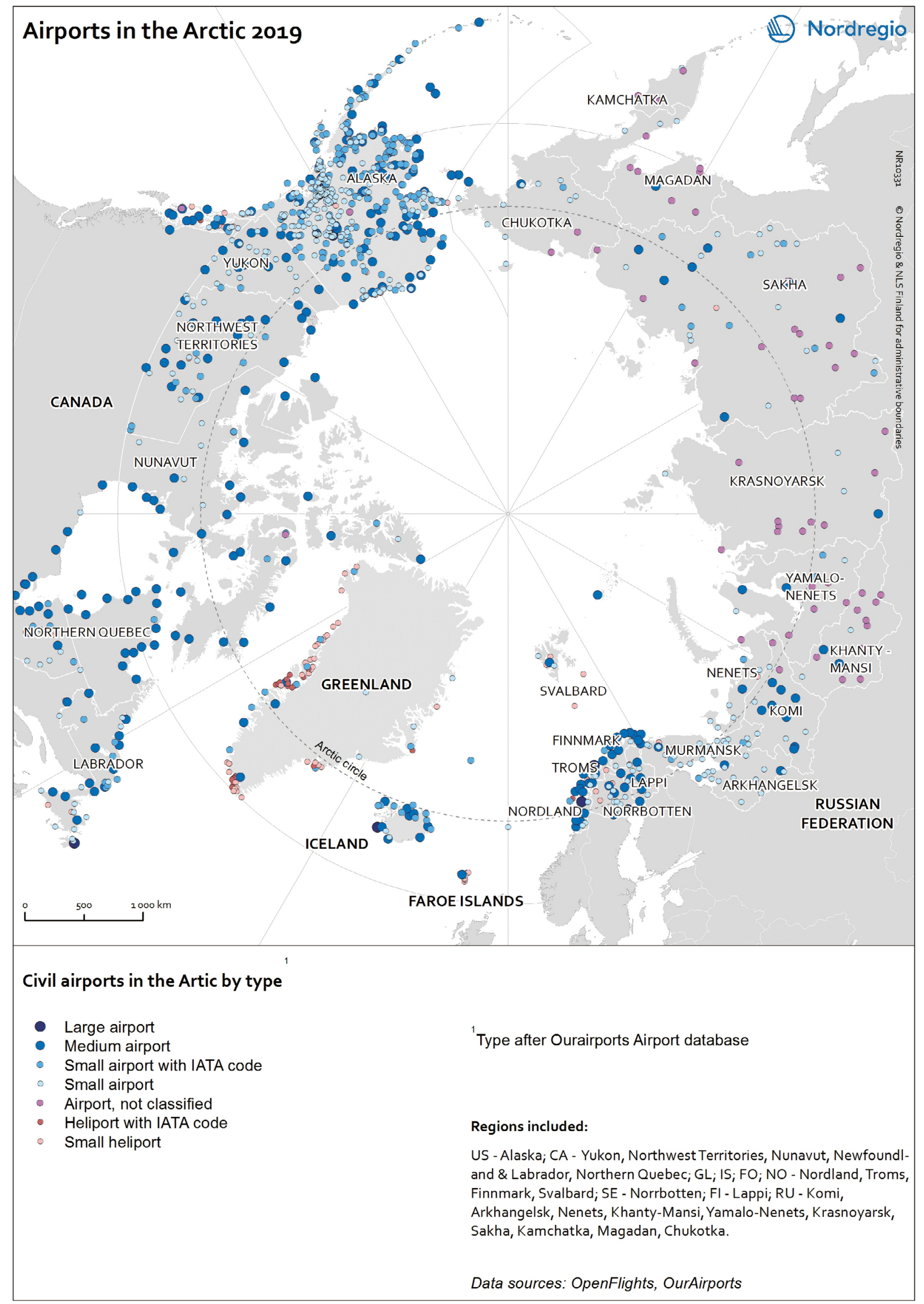

Map: 7-3: Airports in the Arctic. 


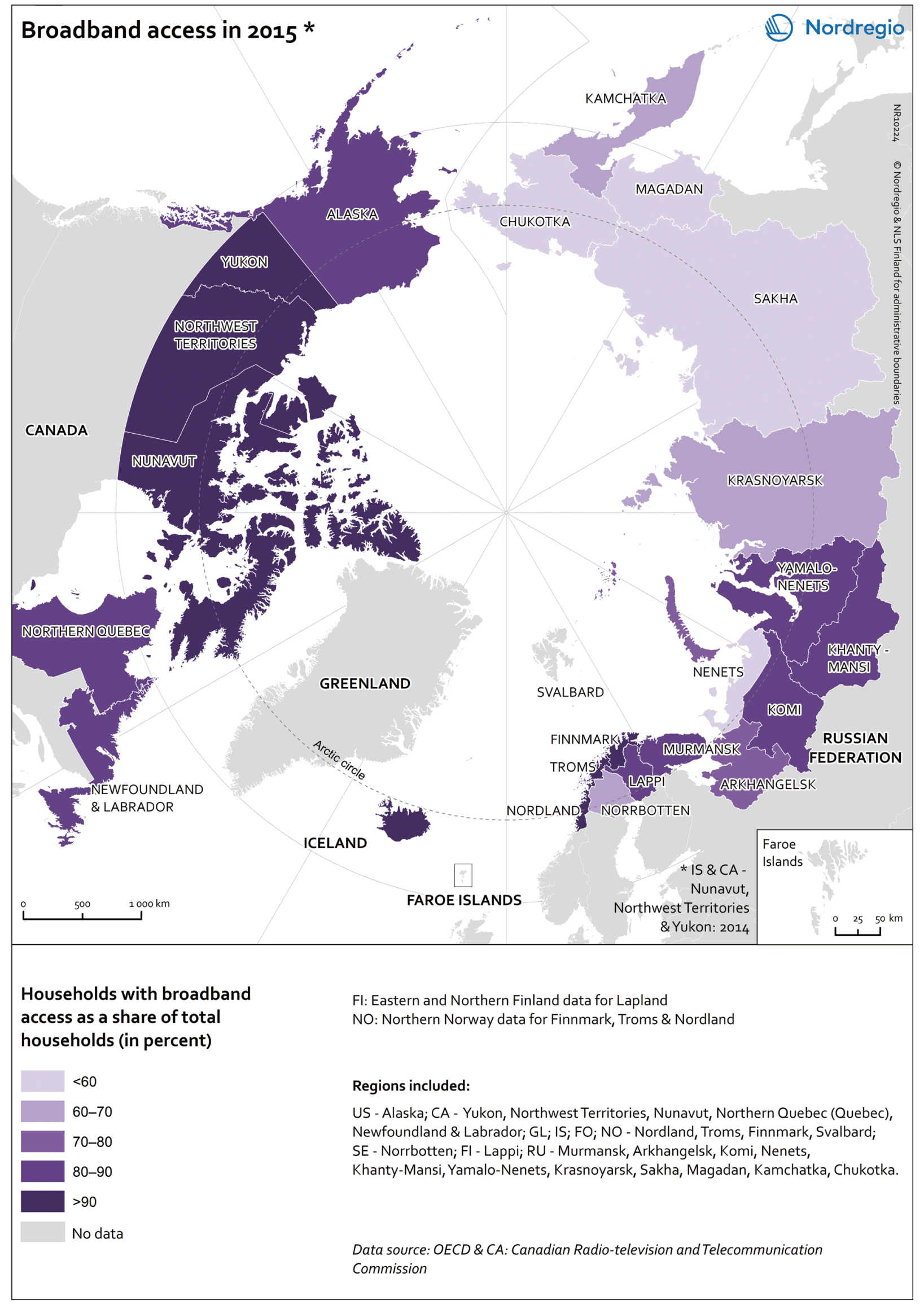

Map 7-4: Broadband access in the Arctic in 2015. 
Arctic region. All of the countries generate hydroelectricity, and it was the major source of production in Norway (96\%), Iceland (73\%), Greenland (68\%) and Canada (58\%). Nuclear power was the second largest source of electricity, exceeding $30 \%$ of the total production in Sweden and Fin- land. Iceland had the highest share of electricity generated by renewable energy sources. Greenland ( 0.6 billion $\mathrm{kWh}$ ) and the Faroe Islands ( 0.3 billion kWh) were the smallest electricity producers in the Arctic.

\section{Electricity generation by source in 2015}

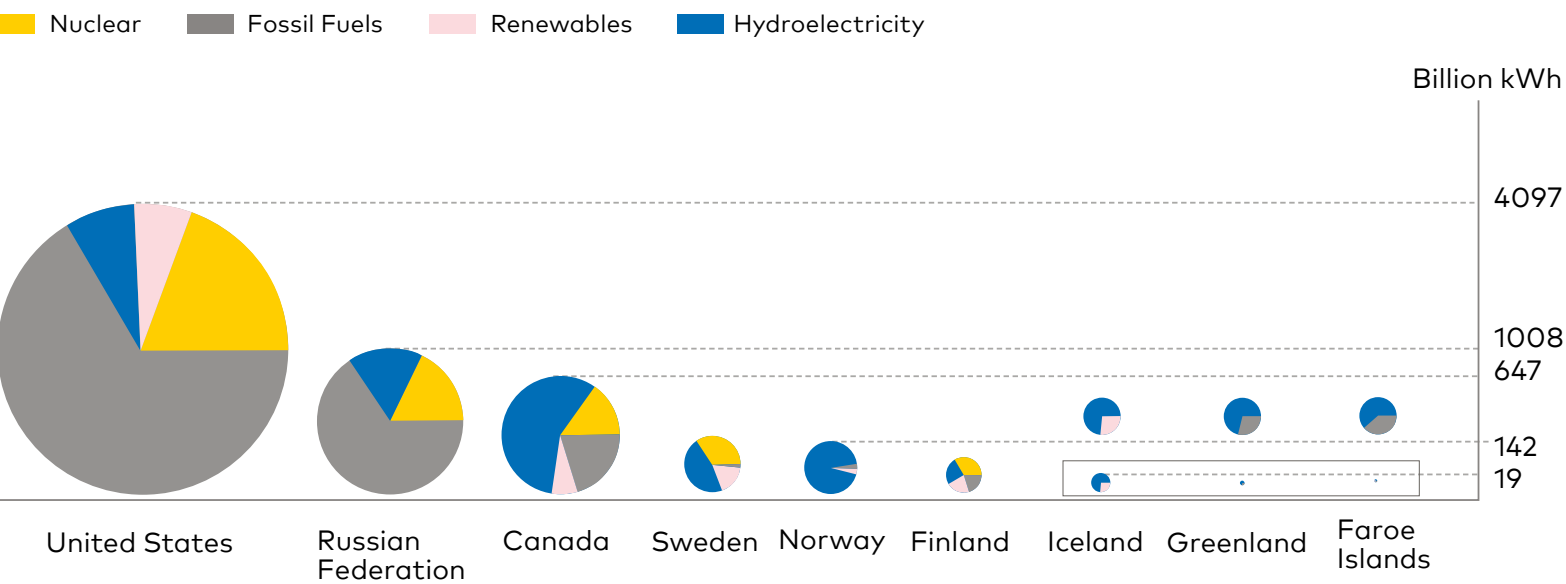

Figure 7-5: Electricity generation by source in the Arctic in 2015.

Data source: U. S. Energy Information Administration. 


\section{Physical conditions and resources}

The Arctic comprises approximately $12 \%$ of the Earth's surface, accounting for $9 \%$ of the total ocean area and $22 \%$ of the terrestrial area. The Arctic landmass is divided into three zones: High Arctic, Low Arctic and Subarctic. There are several definitions of the southern limit of the Arctic, e.g. based on the tree line margin, average temperature and permafrost extent. However, the three Arctic landmass zones are demarcated by climate and vegetation. The marine Arctic is divided into three main groups based on the type of sea ice: permanent, seasonal and marginal. The Arctic coast lies at the border between land and ocean, and includes portions of adjacent marine and terrestrial systems.

Temperatures in the Arctic are low due to weak incoming solar radiation and high albedo. However, Arctic air temperatures are rising faster than the global average. Autumn and winter air temperatures are expected to increase by a regional average of $4^{\circ} \mathrm{C}$ by 2050 - twice the projected warming for the Northern Hemisphere. This increase in air temperature leads to dramatic changes in the Arctic cryosphere.

Map 8-1 shows the main components of the cryosphere in the Arctic: sea-ice, permafrost, ice-sheets and glaciers. Sea ice covers most of the Arctic Ocean during winter, and reaches its maximum extent in March, when it covers approximately 14-16 million $\mathrm{km}^{2}$. Since 1979, the Arctic ice extent in winter has decreased by $3 \%$ per decade relative to the 1981-2010 average, and this trend continues to accelerate. Similarly, ice-sheets and glaciers, which globally cover more than 15 million $\mathrm{km}^{2}$, are melting. In the Arctic, the main ice sheet is the Greenlandic.

Most of the land surface in the Arctic is underlain by permafrost - i.e. ground that remains at or below $0^{\circ} \mathrm{C}$ for at least two consecutive years. The purple shading on Map 8-1 indicates the extent of the northern circumpolar permafrost. Permafrost can be classified as continuous (dark purple, 90$100 \%$ coverage), discontinuous (purple, 50-90\%), sporadic (light purple, 10-50\%) or isolated patches (bright magenta, 0-10\%). The Arctic permafrost is thawing due to increased air temperatures and precipitation. Permafrost temperatures increased by $0.29 \pm 0.12^{\circ} \mathrm{C}$ between 2007 and 2016 .

The Arctic's terrestrial ecosystem is characterised by low tundra vegetation, composed of shrubs, herbaceous plants, mosses and lichens (Map 8-2). Some Arctic vegetation is thriving due to rising air temperatures - for example, an increase has been observed in tall shrub cover. However, lichens and mosses are declining in response to regional warming.

Within the northern circumpolar permafrost region, there are approximately 1,300 protected areas (Map 8-3). Most of these $(1,069)$ are terrestrial, 126 are coastal (defined as partially within the marine environment) and 62 are marine. The World Database on Protected Areas (WDPA) 22 includes a wide range of protected areas, including protected areas recognised by national governments, areas designated under regional and international conventions, privately protected areas, and territories and areas preserved by communities and indigenous peoples. Greenland has the largest extent of protected terrestrial areas (41.0\%).

\subsection{Natural resources in the Arctic}

Map 8-4 shows both existing and potential sites of mineral and energy resources in the Arctic. Throughout the circumpolar region, both exploration activities and the development of production and transport facilities for the extraction of oil, gas and mineral resources are increasing. Receding sea ice cover and permafrost thaw will influence the future accessibility of mineral and energy resources, both on land and in the Continental Shelf.

Map 8-4 shows the main onshore and offshore oil and gas deposits in the Arctic. Information on the specific type of deposit and resource was

22 IUCN and UNEP-WCMC (2019), The World Database on Protected Areas (WDPA) [Online], [January 2019]. Cambridge, UK: UNEP-WCMC. Available at: www.protectedplanet.net. 
taken from several sources. ${ }^{23}$ The main regions in the Arctic linked to oil and gas exploitation are the Beaufort Sea (North Slope, Alaska and Mackenzie Delta, Canada), and the northwestern part of the Russian Arctic (Barents Sea and West-Siberia). Oil and gas are also found in the Canadian Arctic Archipelago (Nunavut). In addition, these three regions have been targeted for future exploitation. According to estimates from the US Geological Survey, the area north of the Arctic Circle is expected to yield recoverable reserves of 90 billion barrels of oil, 1,670 trillion cubic feet of natural gas and 44 billion barrels of natural gas liquids (blue/ purple areas on the map). These resources account for an estimated $22 \%$ of the world's undiscovered and technically recoverable resources. It is estimated that approximately $84 \%$ of estimated resources will be found offshore.

Several metallic and non-metallic minerals, as well as coal resources, can be found in the Arctic. Although the exploitation of these resources is not a recent phenomenon, technical advances and decreasing permafrost and sea ice mean that these resources are becoming more accessible. The grey squares on the map indicate the largest metallic and non-metallic mineral and coal mines in the Arctic. We used the USGS Mineral Resources Data System ${ }^{24}$ and several other data sources in order to collate a balanced and up-to-date picture of mining sites across the Arctic. The main areas for mining activities are the Fennoscandian shield, which has rich metallic and non-metallic mineral resources, as well as the Pechora coal basin in the Russian Federation.

The exploitation and development of the Arctic resources is dependent on global supply and demand, global market prices and political agreements. However, the future of Arctic resource extraction is also highly dependent on technical capacities and environmental challenges, which will increase extraction costs. Increased maritime traffic, e.g. by tankers, will also require new support capabilities, in terms of search and rescue operations and oil-spill prevention. The high economic costs of exploitation and transportation, as well as the high demand for environmental protection, are decisive factors in the exploitation of Arctic resources. 


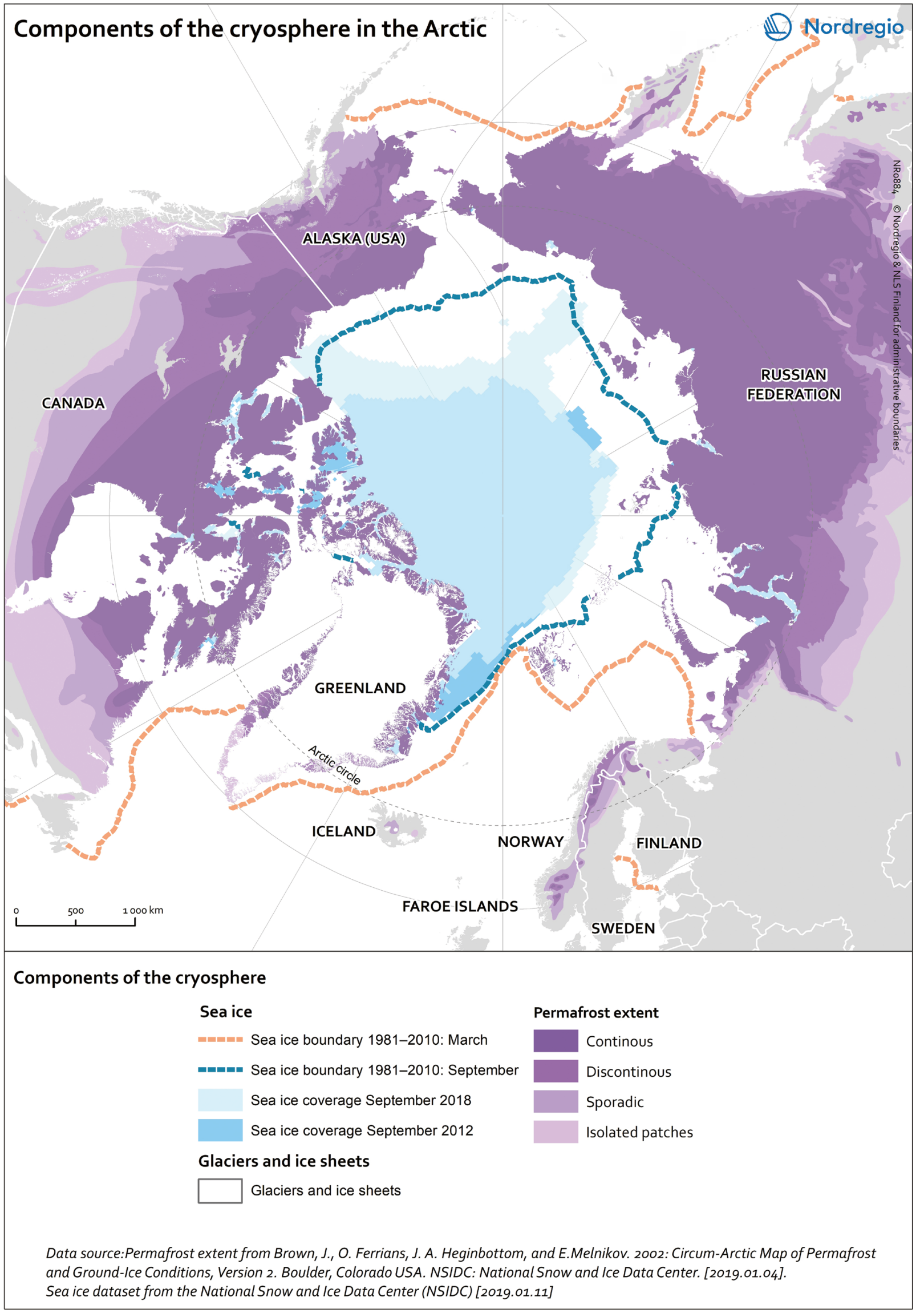

Map 8-1: Components of the cryosphere in the Arctic. 


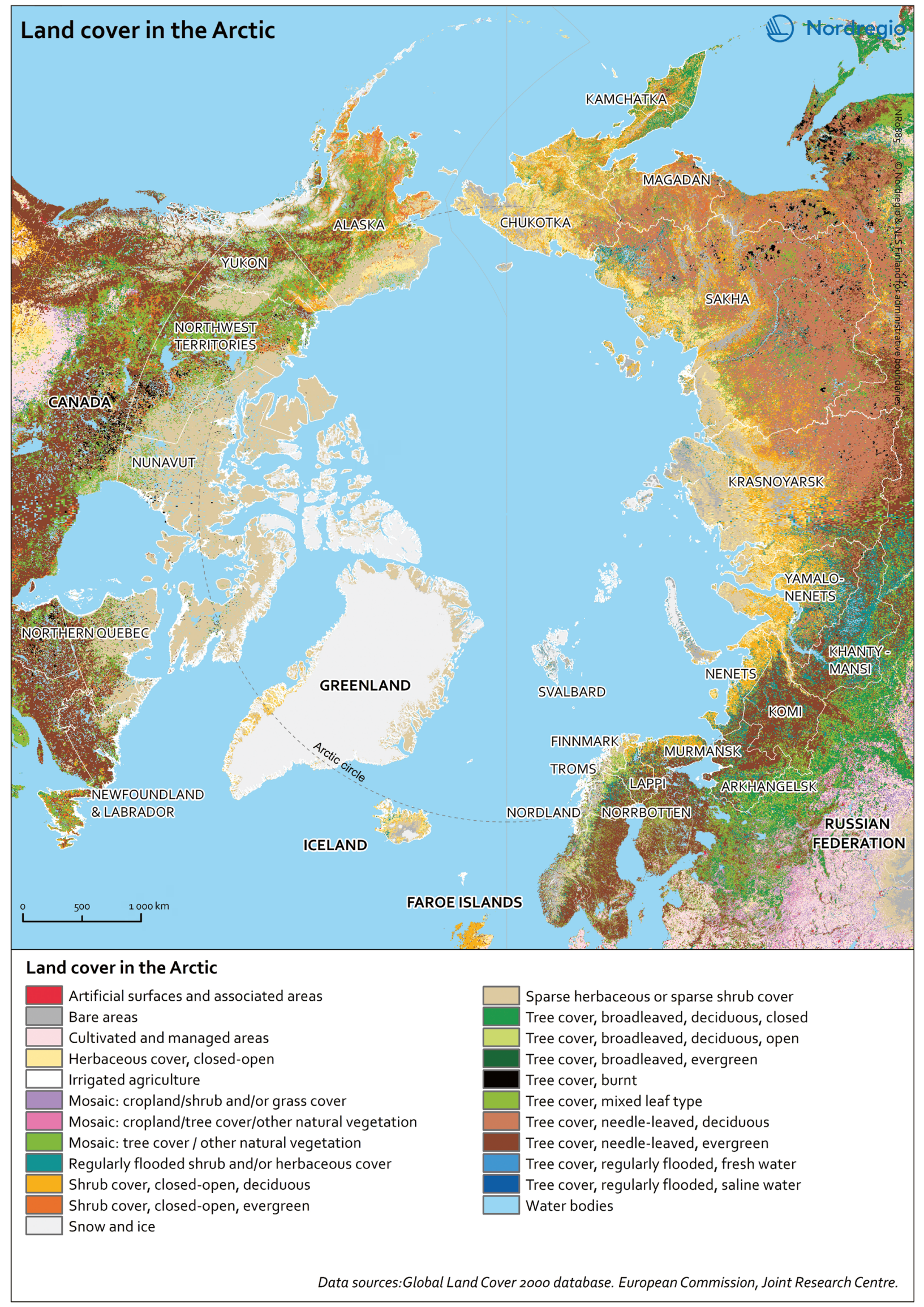

Map 8-2: Land cover in the Arctic. 


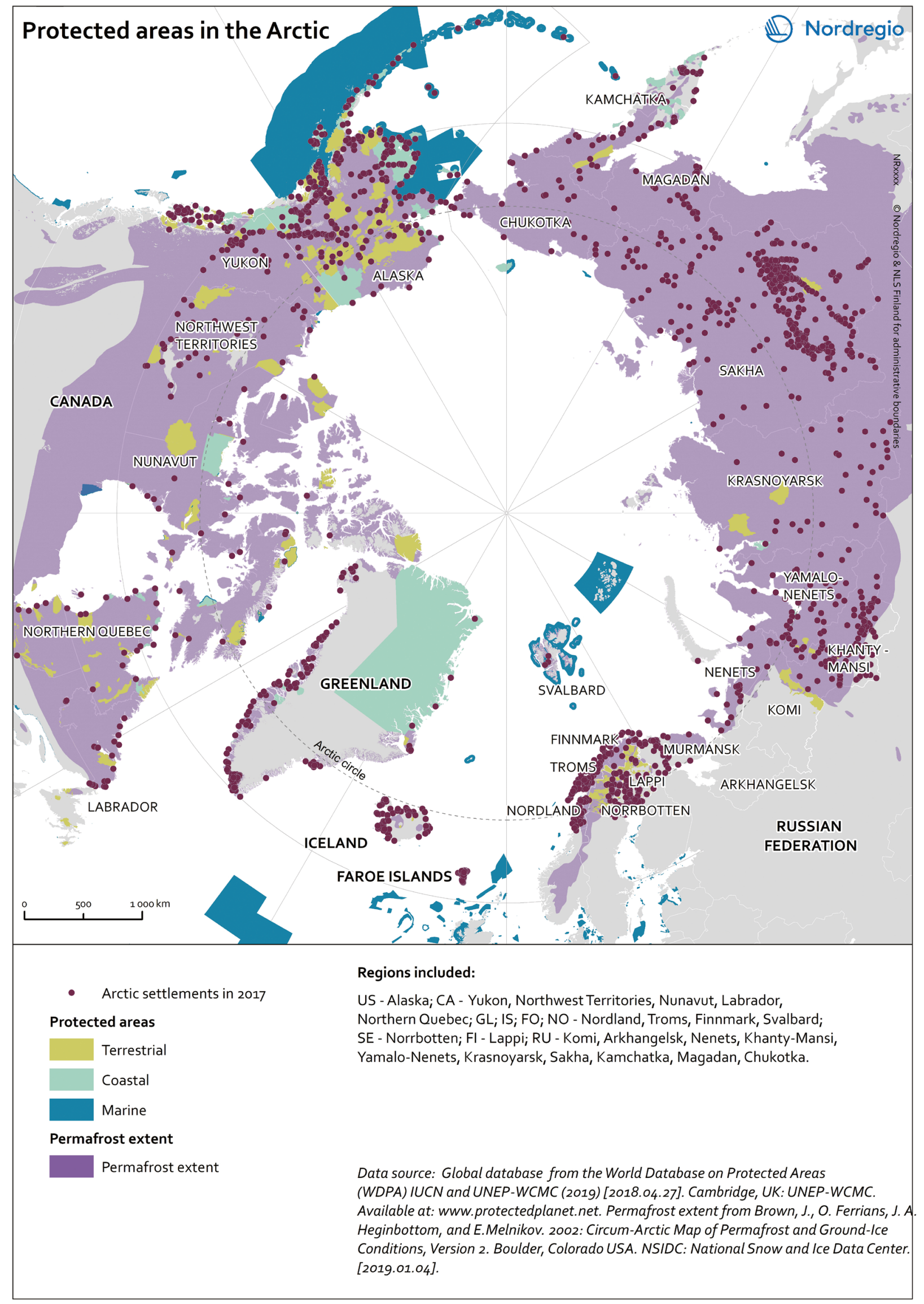

Map 8-3: Protected land and sea areas in the Arctic. 


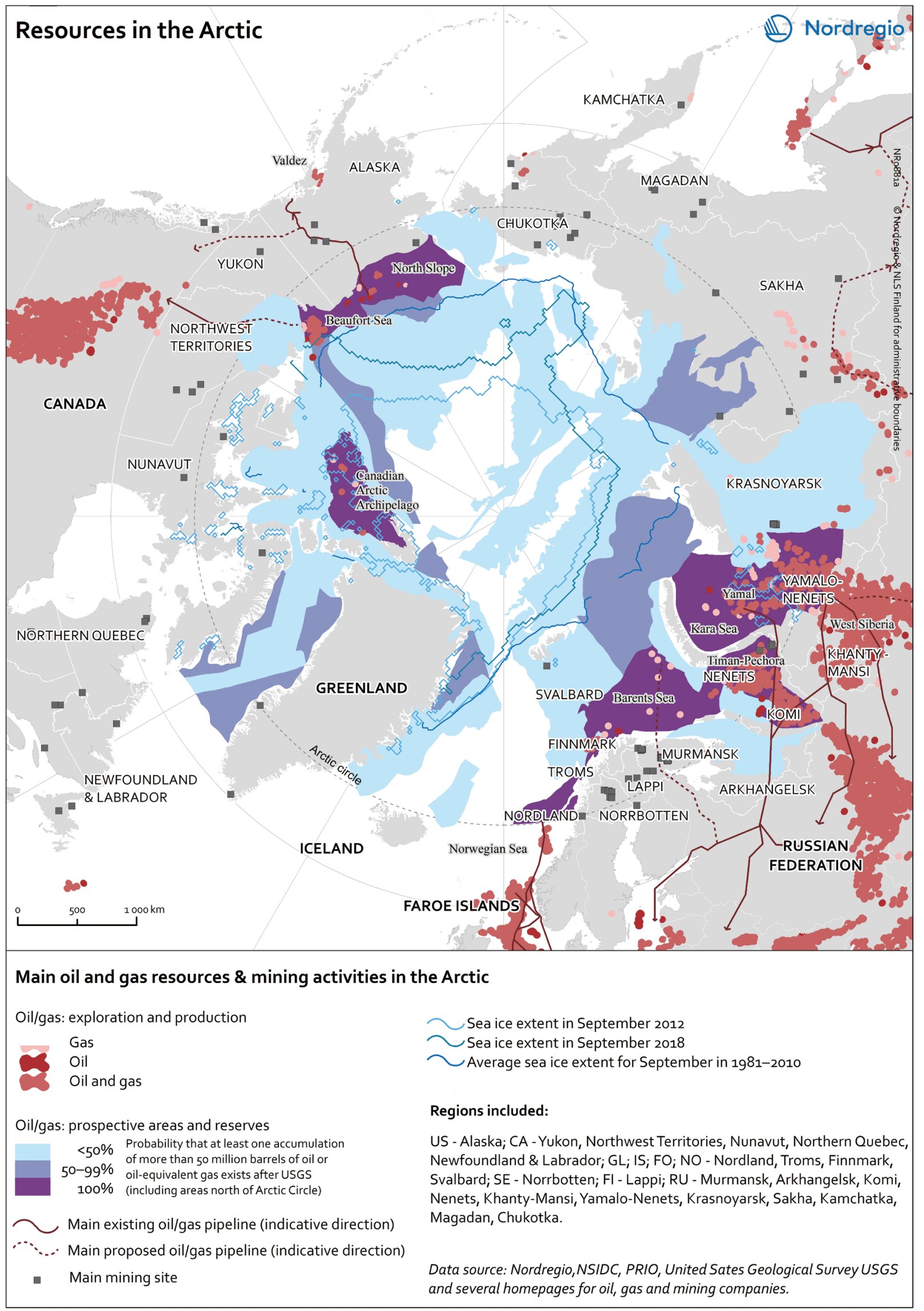

Map 8-4: Resources in the Arctic. 


\section{Appendix}

\begin{tabular}{|c|c|c|c|c|}
\hline Country & State & Economic region & Borouh/Census area & $\begin{array}{l}\text { City \& Census Designated } \\
\text { Place (CDP) }\end{array}$ \\
\hline USA & State & Economic region & Borough/Census area & $\begin{array}{l}\text { City \& Census Designated } \\
\text { Place (CDP) }\end{array}$ \\
\hline Canada & Province & Census division (CD) & & Census subdivision (CSD) \\
\hline $\begin{array}{l}\text { Faroe } \\
\text { Islands }\end{array}$ & & Sýsla & Kommune (Municipality) & Aldur og Bygd \\
\hline Greenland & & & Kommune & Lokalitet \\
\hline Iceland & & Landsværdi & Sveitarfélög & Byggdakjarnar \\
\hline Sweden & & Län & Kommune & Tätort \\
\hline Finland & & Maakunta & Kunta & Taajama \\
\hline Norway & & Fylke & Kommune & Tettsted \\
\hline Russia & & $\begin{array}{l}\text { область/округ } \\
\text { /Республика/ край } \\
\text { (Oblast/Okrug/ } \\
\text { Republics/Krai) }\end{array}$ & $\begin{array}{l}\text { Городской округ/ } \\
\text { муниципальный район/ } \\
\text { (Urban Okrug/Municipal } \\
\text { rayon) }\end{array}$ & $\begin{array}{l}\text { город/ село / поселок/ } \\
\text { нас лег } \\
\text { (city/smaller settlements) }\end{array}$ \\
\hline
\end{tabular}

\section{Appendix Table 1.2: List of Arctic regions}

\begin{tabular}{|c|c|}
\hline Name of Region & Definition \\
\hline \multicolumn{2}{|l|}{ Alaska } \\
\hline Alaska & State of Alaska, part of the US \\
\hline \multicolumn{2}{|l|}{ Canada } \\
\hline Northwest Territories & A federal territory of Canada \\
\hline Nunavut & A federal territory of Canada \\
\hline Yukon & A federal territory of Canada \\
\hline $\begin{array}{l}\text { Nunavik/Northern } \\
\text { Quebec }\end{array}$ & $\begin{array}{l}\text { Nunavik comprises the northern third of the province of Quebec, Canada, in } \\
\text { Kativik, part of the Nord-du-Québec region. Due to negotiations for regional } \\
\text { autonomy and the resolution of outstanding land claims, the name 'Nunavik' is } \\
\text { used in this study instead of AHDR's 'Northern Quebec' }\end{array}$ \\
\hline Quebec & $\begin{array}{l}\text { When no data are available for Nunavik alone, data for Nord-du-Québec or for } \\
\text { Quebec as a whole are used }\end{array}$ \\
\hline $\begin{array}{l}\text { Newfoundland and } \\
\text { Labrador }\end{array}$ & A federal territory of Canada \\
\hline Manitoba & Canadian province. Only settlements closest to Hudson Bay included \\
\hline Ontario & Canadian province. Only settlements closest to Hudson Bay included \\
\hline \multicolumn{2}{|l|}{ Faroe Islands } \\
\hline Faroe Islands & Føroyar (in Faroese). An autonomous country within the Kingdom of Denmark \\
\hline
\end{tabular}




\begin{tabular}{|c|c|}
\hline \multicolumn{2}{|l|}{ Finland } \\
\hline Lapland & Lappi (in Finnish). Northernmost county in Finland \\
\hline \multicolumn{2}{|l|}{ Greenland } \\
\hline Greenland & $\begin{array}{l}\text { Kalaallit Nunaat (in Greenlandic). An autonomous country within the Kingdom } \\
\text { of Denmark }\end{array}$ \\
\hline \multicolumn{2}{|l|}{ Iceland } \\
\hline Iceland & Ìsland (in Icelandic). Whole country \\
\hline \multicolumn{2}{|l|}{ Norway } \\
\hline Nordland & County in Norway \\
\hline Troms & County in Norway \\
\hline Finnmark & County in Norway \\
\hline Svalbard & $\begin{array}{l}\text { Norwegian archipelago in the Arctic Ocean. Norwegian Longyearbyen and Ny- } \\
\text { Allesund and Russian Barentsburg are the only permanently inhabited places }\end{array}$ \\
\hline \multicolumn{2}{|l|}{ Sweden } \\
\hline Norrbotten & County in Sweden \\
\hline \multicolumn{2}{|l|}{ Russian Federation } \\
\hline Murmansk & Murmansk Oblast (Мурманская область) \\
\hline $\begin{array}{l}\text { Nenets (Arkhangelsk } \\
\text { Oblast) }\end{array}$ & $\begin{array}{l}\text { Nenets Autonomous Okrug (Ненецкий автономный округ). } \\
\text { When no data are available for Nenets only, data for Arkhangelsk Oblast as a } \\
\text { whole are used }\end{array}$ \\
\hline \multirow{2}{*}{$\begin{array}{l}\text { Novaya Zemlya } \\
\text { /Arkhangelsk }\end{array}$} & Novaya Zemlya (Новая Земля) in Arkhangelsk Oblast (Архангельская область) \\
\hline & $\begin{array}{l}\text { When no data are available for Novaya Zemlya only, it is either indicated by 'no } \\
\text { data' or data for Arkhangelsk Oblast as a whole are used }\end{array}$ \\
\hline \multirow{2}{*}{$\begin{array}{l}\text { Vorkuta } \\
\text { /Komi }\end{array}$} & City region of Vorkuta (Воркута) in Komi Republic (Республика Коми) \\
\hline & $\begin{array}{l}\text { When no data are available for the city of Vorkuta only, data for Komi Republic } \\
\text { as a whole is used }\end{array}$ \\
\hline Yamalo Nenets & Yamalo-Nenets Autonomous Okrug (Ямало-Ненецкий автономный округ) \\
\hline Khanty-Mansi & $\begin{array}{l}\text { Khanty-Mansi Autonomous Okrug (Ханты-Мансийский автономный округ - } \\
\text { Югра) }\end{array}$ \\
\hline \multirow[t]{2}{*}{$\begin{array}{l}\text { Taymyr, Norilsk, } \\
\text { lgarka and Evenkiyskiy } \\
\text { municipal district } \\
\text { (rayon) }\end{array}$} & $\begin{array}{l}\text { Regional Self-Government of Taymyr Dolgano-Nenets Autonomous Okrug in } \\
\text { Krasnoyarsk Kray (Официальный сайт органов местного самоуправления } \\
\text { Таймырского Долгано-Ненецкого муниципального района) }\end{array}$ \\
\hline & $\begin{array}{l}\text { Krai city of Norilsk (Норильск) geographically located within Taymyr } \\
\text { Autonomous Okrug and the city of Igarka (Иrapкa), with surroundings in } \\
\text { northern part of Turukhansky District and Evenkiyskiy municipal district (rayon) } \\
\text { (Эвенкийский муниципальный район) in Krasnoyarsk Krai (Красноярский } \\
\text { край). }\end{array}$ \\
\hline /Krasnoyarsk & $\begin{array}{l}\text { When sub-regional data are not available, data for the Arctic part of } \\
\text { Krasnoyarsk Krai are used }\end{array}$ \\
\hline Sakha & Sakha Republic (Yakutia) (Республика Саха (Якутия)) \\
\hline Chukotka & Chukotka Autonomous Okrug (Чукотский автономный округ) \\
\hline Kamchatka & Kamchatka Krai (Камчатский край) \\
\hline Magadan & Magadan Oblast (Магаданская область) \\
\hline
\end{tabular}





\section{(1I) Nordregio}

P.O. Box 1658

SE-111 86 Stockholm, Sweden

nordregio@nordregio.org

www.nordregio.org

www.norden.org

ISBN: 978-91-87295-79-9

ISSN: 1403-2511

DOI: doi.org/10.30689/WP2019:3.1403-2511 